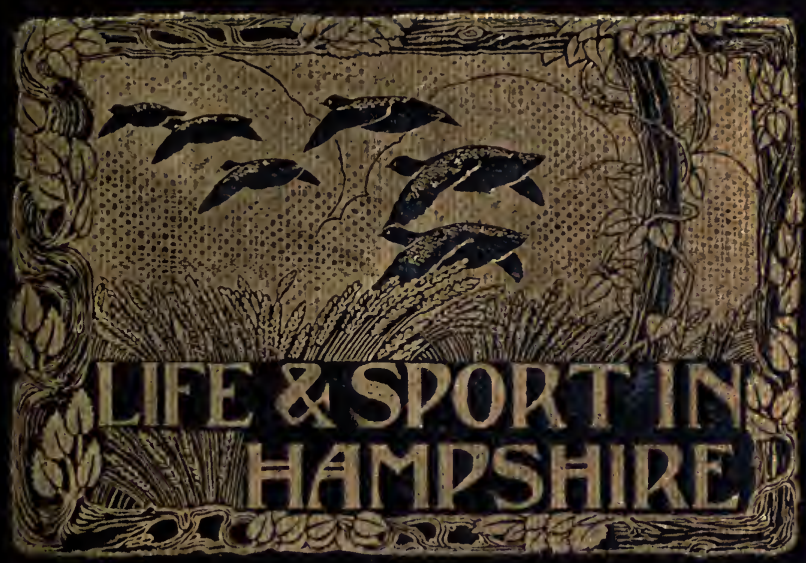





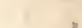

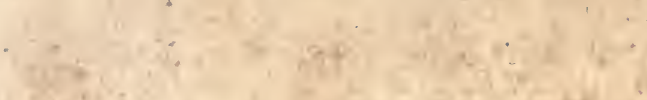

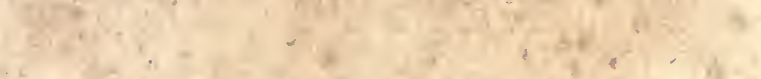

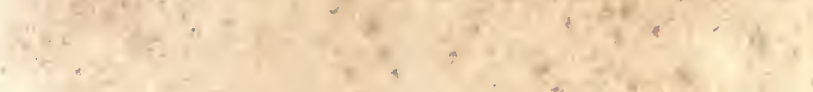

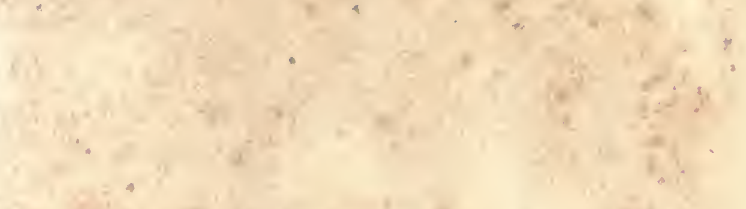

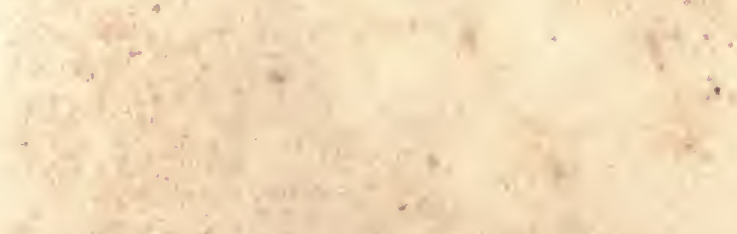

$$
\begin{aligned}
& \text {, }
\end{aligned}
$$

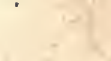

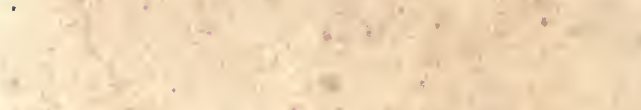

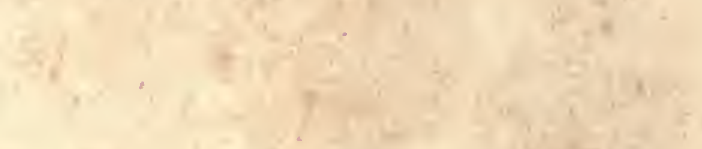
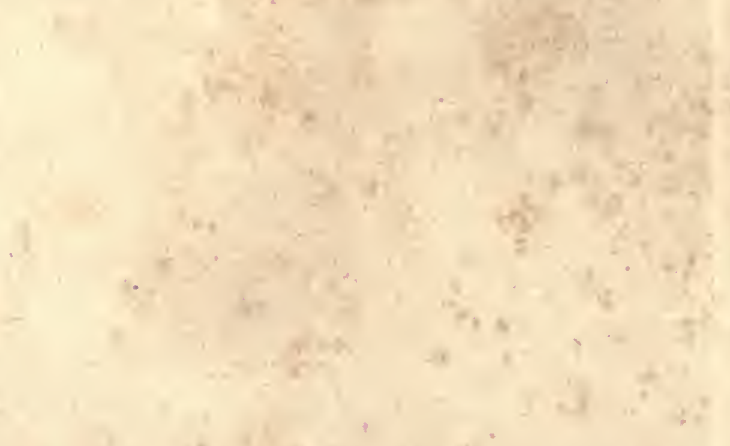



\title{
LIFE AND SPORT IN
}

\author{
H A M P S H I R E
}






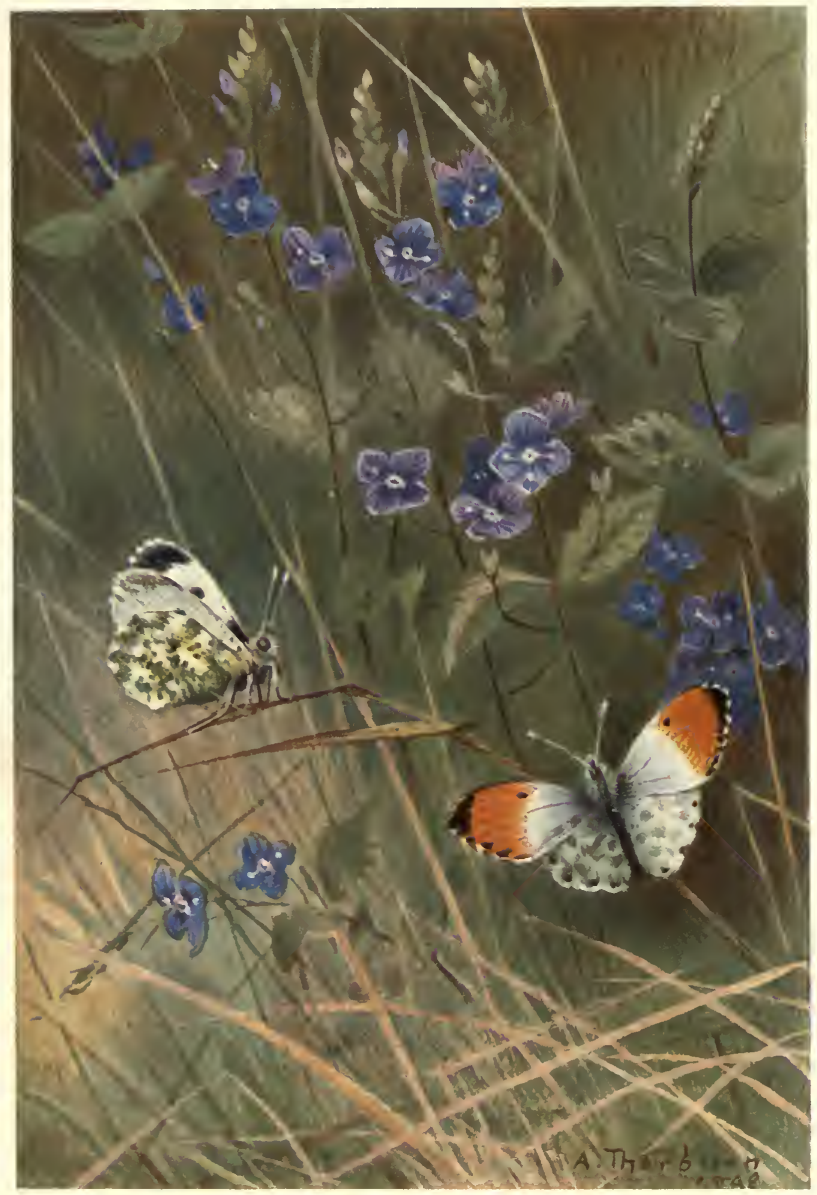

ORANGE TIP AND SPEEDWELL.

From a Water Colour Drawing by Archibald Thorburn. 


\section{LIFE AND SPORT IN HAMPSHIRE}

BY

GEORGE A. B. DEWAR

AUTHOR OF " THE GLAMOUR OF THE EARTH," “THE BOOK OF THE DRY FLY," " WILD LIFE IN HAMPSHIRE HIGHLANDS,"

“THE BIRDS IN OUR WOOD," ETC.

WITH 2 COLOURED PLATES BY A. THORBURN

4 PHOTOGRAVURE PLATES

AND ILLUSTRATIONS FROM PHOTOGRAPHS

L O N G A NS, GREEN, A N D CO.

39 PATERNOSTER ROW, LONDON NEW YORK, BOMBAY, AND CALCUTTA

1908

All rights reserved 



\section{B. D.}

"The gift. . is immeasurably above all ambition, more precious than wealth, more noble than name. He knows not life who knows not that."

Thackeray. 
"I have a crystal treasure box, Its stores are beld from me; I cannot foree its thousand locks, And have no master key."

Ralph Hodgson. 


\section{T H E L A N D}

Most of this book is an account of wild life and sport in north-west Hampshire, a district of large woods and clear streams and great rolling chalk downs, where my family has been settled on the land for generations. The woodland has always appealed to me more than any other place, but a good many passages relate to the last five years spent largely in the pleasant village of Oakley, fourteen or fifteen miles east of my own district. Portions of the book have in substance appeared in the Standard, and I thank the owner and the editor for allowing me to reprint them here. I hope that what I have said in the last chapter about the peasantry and the small farmers will not be taken as harsh or hopeless. I have absolute sympathy with those who wring a living and independence out of a few acres of English soil. The small man in land is invaluable in our country.

Where he sternly endures in hard conditions he is 
viii THE LAND

made of real character. The oak and iron of England is in him. $\mathrm{He}$ is the man.

I would like to see him planted firmly in every English village and hamlet. The State does wisely if it encourages him carefully. But let there be no mistake about this. The small man in land, if he is to be the real man and the useful man and the enduring, must in the main make himself. 


\section{O N T EN TS}

THE TAGE

CHAP.

I. THE WOOD HOME. . . . . . . 1

II. A GIFT OF GOD . . . . . . . 11

III. THE SINGERS . • . . . . . 43

IV. BIRDS AND THEIR VOYAGES . . . . 77

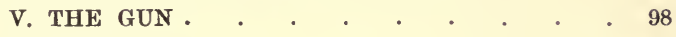

VI. AT THE ESTUARY . . . . . . 127

VII. THE ANGLER . . . . . . . 142

VIII. INSECT LIFE • . • • • • • • . 162

IX. INSECT LIFE (Continued) • . * . 190

X. THE GREEN WORLD . . . . . . 213

XI. THE NATURAL MAN • . . . . . 244

INDEX $\quad . \quad$. $\quad . \quad$. . . . 271 



\section{LIST OF ILLUSTRATIONS}

\section{COLOURED PLATES}

From Drawings in Colour by ARCHIBALD THORBURN.

Orange-tip Butterflies and Speedwell • Frontispiece

Six-spot Burnet Moths and Knapweed - To facep. 190

\section{PHOTOGRAVURE PLATES}

High Midsummer . . . . . . . " 60

From a Photograph by Miss HiLton FAGGE.

The Lower TesT . . . . . . " 144

From a Photograph by Miss HiLton FAGGe.

A Fritillary Wood . . . . . " " 210

From a Photograph by Messrs. Spooner.

The Great Knightwood OAK . . . " 240

From a Photograph by Messrs. SpOoner.

\section{FROM PHOTOGRAPHS}

The Spelit of Whisperivg Woods

From a Photograph by Mr. Cook, of St. Mary Bourne.

The Figure of Eight . . . . . " " 21

At the Wood's Heart . . . . . " " 47

From a Photograph by Mr. Cook, of St. Mary Bourne. 
Absolute Chalk Stream $\quad$ - . $\quad$. $\quad$. To face p. 99

From a Photograph by Mr. Соok, of St. Mary Bourne.

Kimbridge
From a Photograph by Miss Hilton FagGe, by kind leave of Mr. ARTHUR HUMBEKT.

Bransbury Common . . . . . . . " " 176

From a Photograph by Mr. Cook, of St. Mary Bourne.

The Ancient Beech Wood . . . . " 223

From a Photograph by Messrs. SpOONer.

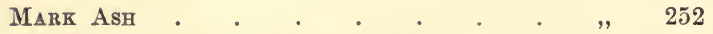

From a Photograph by MESSRS. SPOONER. 


\section{LIFE AND SPORT IN HAMPSHIRE}

\section{CHAPTER I}

\section{THE WOOD HOME}

I sHaLL be content if I can bring into my pages some idea of the charm about life in a wood-a wonderful, subtle charm! Nearly all my early years were lived in the midst of the oaks and hazels, and the spell of those whispering woods has never lost its power over me. I think it never can. Downs, smooth and rolling downs, bare and breezy, are noble places. They bring a fine uplifting to the heart, when on summer days we climb up and lie high among their thymes. The soul of a man grows and is felt in such spots on a good June day; and we know the same about the steeps by the sea. Perhaps a large wood with its gleaming rides and glades has not quite this power to lift up the spirit with joy. It wants the immense skies and long horizons, the bracing air and that blue of the far landscape that always-from some cause not clear to me-touches us so closely. The high places, inland or by the sea, with their sense of space, 


\section{LIFE AND SPORT IN HAMPSHIRE}

their largesse of sun and breeze, have an exhilaration for spirit and body which, I admit, I do not find in the quiet thick wood where timber and underwoods are mixed. But there is a peculiar feeling of home about a large, quiet wood, once we have spent years in it, and come to care for it greatly, which never leaves us. An intimacy between the wood and its inhabitant is formed, and this grows very close. Home, perhaps, in its more restricted and meaning sense must be actually a house stored with present and past and with hopes and thoughts of the future. A wood, however, grows very homelike after a time. Many of its distinctive and favourite scenes become as rooms in a house where we were bred. We carry them about in thought, and they are delightful to look at, often when we have been absent for a long time from the scene. In the mind's eye-eye of such range and power to focus-a score of scenes in the depths of the wood, and at its margin long and irregular and miles round, can be commanded in quick succession at any time; and the exact grouping of the oak and ash trees, the rise and fall of the ground, knoll and hollow, the very patches of tall bracken and the cover of underwood, all are reproduced in the thought-picture with faithfulness to Nature. If the old chair or corner cupboard or bookcase at home can appeal to us as a friend, the tree in the wood home will awake often the same feeling. We carry about memories of old familiar trees for years with us-for a lifetime indeed 
- trees we climbed and bird-nested in; their networks of sun and shade in full summer; their living tints at the birth of the leaf in early spring-no tints or colours in the wood year burn with such a look of life as those of oaks and beeches of April and May; and the curious configuration of their familiar branches, even their familiar twigs, as set against the cold, pure washes of December sunsets.

These are the homelike touches with which a native or long known and favourite wood is always pleasing us. Besides, the wood holds us by another thing. It holds us charmed by the sense of mystery in which it seems steeped at almost every hour and in almost every state of light and foliage, and in each of the seasons. The deeper the wood, the deeper the mystery. And this wood is, for an English one, very deep. It is some miles round. This of itself does not imply depth in the sense of quiet and absolute seclusion. It need scarcely imply an acreage in four figures, though in this case I think it does, with the common in the midst of the woods, reach nearly to the thousandth acre. There are stretches of forest, Crown or national land, which cover a large extent of country, and yet are wanting in that depth of quiet and aloofness which is great part of the wood charm. Where such stretches of forest fail is that they are more or less civilised: there is a sense of planting about them; enclosures are marked out here and there. Public ways lie through them, bridle- 


\section{LIFE AND SPORT IN HAMPSHIRE}

paths perhaps; from time to time the sound of a swing-gate falls on the ear. I value highly such public rights; but the fact remains that a wood with footpaths and bridle-ways, trod by many feet, must lose this possession of depth. Nature in such spots does not seem to brood upon herself. Her reveries are always subject to interruption; and then for a while the mystery, the day mystery at least, is gone. The place, however good to look at, becomes humanised: the fairies and fauns of it, shyest of folk, are scared off. I think the footfall of one stranger from the outer world-with that outer world in his thoughts-will scare them away for hours. True, at dusk they may return, but that is another matter; at dusk they may be at home in almost any wood, even in little coppices and plantations within sound of a city that lights with its dull glare the sky high above their tree tops.

There is a thing besides extent of ground covered, and aloofness from the outer world, that makes for depth and mystery in a wood-thick underwood and undergrowth. For the best landscape effects, for landscape gardening on a large scale, thick underwoods are often a drawback. They prevent those long vistas and views which tell in a picture. The trained eye for a landscape will prefer at least to break them up, have here a patch of thick underwood, there a break through which the eye can travel and admire a distant glade or knoll or hollow. The forms of the oak trees cannot be seen to full 
advantage where the underwood is thick and growing high. In ten or fourteen years' growth, underwood of hazel and ash and oak stems mingled will rise into something like a solid wall, which shuts out what otherwise might be half a mile of view. I often hear this urged against the monotony of thick underwood among the oak trees, and it is a fair objection from the point of view of artist or of landscape gardener. Try to make many pictures of these deep, thick underwood scenes, and the thing is evident at once. A little broken plantation of large trees, with only brake fern and rough grasses and flowers for undergrowth, will yield more pictures than a great wood such as I write of. Large, solid, deep underwoods cannot be got on to the canvas with much success. Think of the New Forest as a forest of thick underwoods throughout, and its picture and landscape effects largely disappear: a thousand acres of the Forest then would not yield as many pictures as a single acre in many parts of it, say at Sway or Minstead, yields to-day. Underwoods, too, hinder the full spread and growth of timber, as timber lessens the crop of underwood. The noblest oaks in the New Forest, as the Knightwood Oak in Mark Ash, are free of underwoods.

It is the same everywhere. Great trees, having a great hunger and thirst, will not brook little rivals; they need all the good of the soil and 


\section{LIFE AND SPORT IN HAMPSHIRE}

the air and space within their sphere for their sole use.

These are arguments against the underwoods. Country economy adds others. The crop of hazel, ash, and oak underwoods ten or fourteen years old in so many places to-day has not a fourth of its old value. Where in the 'sixties and 'seventies it would fetch twelve, even sixteen, pounds an acre for wattlehurdles and faggots or bavins, it fetches but three or four to-day. Less and less we bake our bread slowly in the good brick oven heated by an underwood fire that burns out in the clean grey ash. No loaf tastes so good and wholesome as the woodbaked loaf. Our fathers in this were the truer epicures. But we cannot wait for such a slow baking now. Coal, too, is hawked about in small quantities almost everywhere; and there is the little oil-stove for the villager. So the faggot or bavin, in old days one of the necessities of the villager, part of the staff of life, has lost much of its worth. The stack of underwood, piled high against the back of the old thatched cottage, is still seen in hamlets, giving a warm and pleasing idea of forethought against the winter; but every year I see now what I never saw as a boy-small wood, in faggots or loose, rotting in the coppices. Sometimes, to rid the ground of it, the woodman will make a bonfire of the rougher stuff which in old times was always worth binding together and carting from 
the coppices. I have fancied sometimes that the very cart-ruts along the woodland sides are not so deep as they were!

But when all has been said against these great solid coverts of underwood mixed with timber-the eye for effect and the eye for profit seeing alike-I keep old fondness for them. Surely those woods where Hazlitt could wander and lose himself as he could wander and be lost in the deeps of his heart were underwood in part? The straight wands of ash and hazel, the birch clumps with their grey and brown stems-miles of these, deeps leading into deeps of underwood, with the oak-tops and sighing fir trees at a height we never thought of reaching even in climbing days, make a mystery that is found in few other spots in homely England. Wild places often seem to have personality after dark. It is as if the heath and the marsh woke to a sort of consciousness then. But the wood seems to have it even by daylight, and among the wands of hazel and ash one feels this most. Then those winding footpaths among the underwoods, they grow most secret when the branches in spring and summer are suffered to grow across them. They are hardly artificial paths; they are half wild in the way they wind in and out, the hunter or keeper who first trod them for a short-cut through the shoots going round the stem or tree that lay in front of him. There could not be a more natural making of a woodland path; the rabbits' run 


\section{LIFE AND SPORT IN HAMPSHIRE}

is not more natural; indeed, these paths might well be described as the woodman's or the keeper's run in their origin, though later they may be trimmed for the sake of the fox-hunt. I remember hearing-for this kind of fact is in the oral history of an old landfamily like ours-that the larger and broader paths and rides were cut and grubbed simply for the hunter. This was Assheton Smith himself. Few, if any, who once followed him among these oaks and underwoods are now alive to tell of it. But $I$ can recall one or two who were with the man of iron. There was the sporting villager, a very distinct figure of our childhood, who had tales to tell of the stern hunter. This village worthy believed in two things perhaps above all else by which countryside and folk could thrive-good red meat, and the merry sound of horn and galloping hoof; quite an honest belief, though partly mixed up with his livelihood, for he was the butcher. The grey or dappled grey which he long rode I can just recall by an odd freak of memory, and that he had a sort of scornful pity for weaklings who could not buy butcher's meat. The other was a pastor, who lived by the noble grey ridge of down to the north. This man, too, loved hound and horn, and I believe he had ridden with Nimrod. But somehow I have carried a memory of him as one who might have figured better in "The Excursion" than in the rush and colour of the hunt; perhaps because he was a very quiet man in manner and in dress, and because $I$ can just recall part of a 


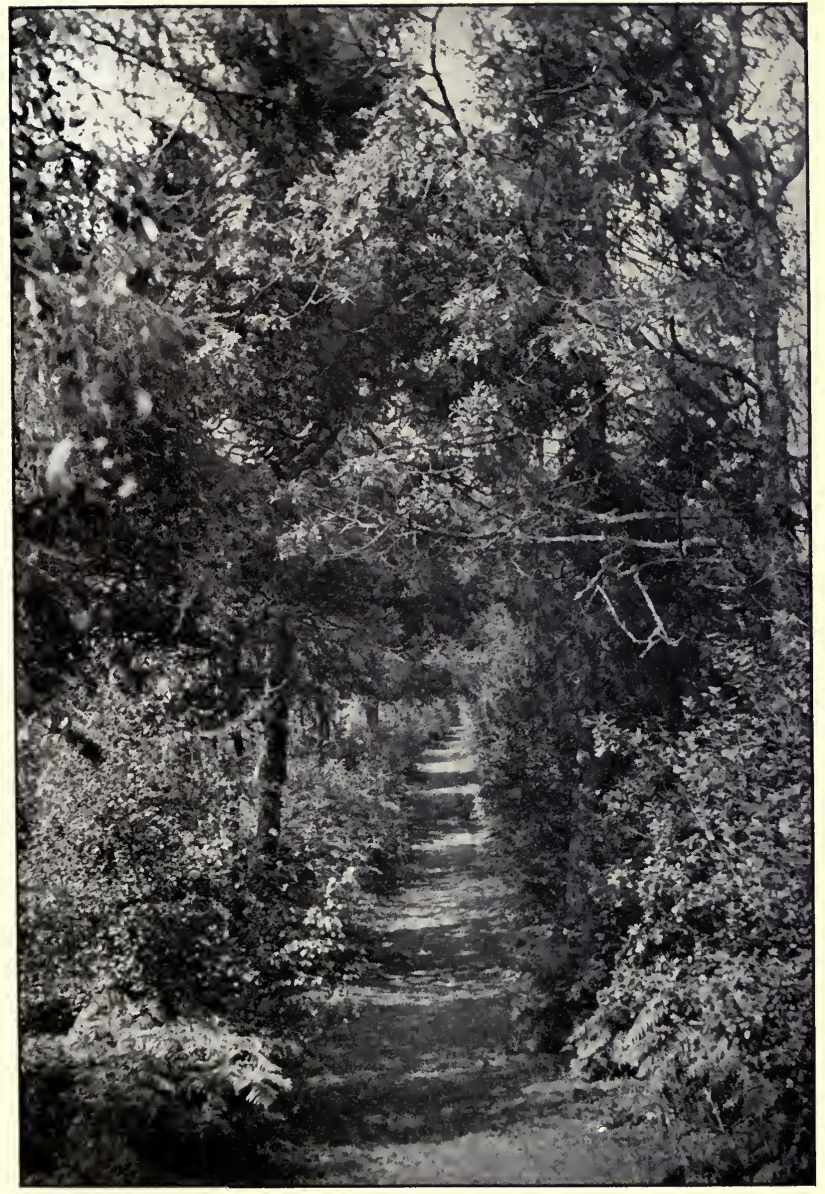

The Spell of Whispering Woods. 

lonely ride with him towards home across a bit of country with a few remote farmhouses and a few scattered thatched cottages.

It can hardly be altogether fancy or partiality that in this land of chalk downs and chalk streams and of oak and hazel woods one finds above all a great freshness. This seems a quality of all the country round about. Could any one not recognise it as a quality of the hills and valleys round Winchester, where we celebrated this summer the thousandth year? I have felt it through and through me, not only in the vale of the river-where the stream divides and divides again to make the freshness fresher-but on the turf of the downs far from sight of water and the rich green which the water makes. It seems to have been noticed by a poet nearly a hundred years ago. William Arnold reminds us that Keats stayed at Winchester, and he thinks that out of the visit came "The Eve of St. Mark," a rare and curious fragment; and that Keats was struck by the freshness of the district. Keats could write down the little landscapes, hillock, rill, and spinney, so entirely typical of southern England, as perhaps no other English poet. About his minutiæ in pictures of English idyll there was a touch faery-fine-exquisite inventories of field and wood. And it is easy to understand how this bit of country full of idyll would appeal to him. But in calling it "fresh" I do think we have a name that above any other possible description fits exactly. 


\section{LIFE AND SPORT IN HAMPSHIRE}

Returning to the hamlets among the hills or in the little valleys - Test and Itchen, Anton and Annaafter an absence of a few months perhaps, we feel this freshness go into us. In March or early April, even in backward seasons, I have often found it so.

These places have the gift at once to quiet and to exhilarate.

Freshness everywhere-the earth is steeped in it; in the elmy lanes leading out of river hamlets, on the commons, though gorse be not yet gold, along the thin, old hedges of thorn and maple on windy hillsides, and-almost more than anywhere-in the hazel coppices where the hurdler has piled his white split wands against the oak. The thing goes into one's heart and head. English countryside has no quality so easily communicated to us or quite so curing. 


\section{CHA P T E R II}

\section{A GIFT OF GOD}

Nothing in Nature has appealed to me quite so much of late years as the flight of a bird. Here is one of those very familiar sights of every open-air hour of our lives which we take for granted from early childhood. So familiar is it that even watchers of birds, and those who care greatly for the beauty and wonder of Nature, may pass through life without taking much note of it. True, the breathless-looking balancing feat of the red hawk, its head pointing into the wind with the sureness of a vane, rarely grows quite familiar. It has the constant power to make us wonder. Watching the hover of the hawk, and noting how, after the feat, it would sweep in a spiral flight upward, brought straight home to me one day a sense of the glory and triumph of wings; and I have found since that there are many common aerial feats of birds and insects as curious and charming to study as the windhover's, if not so striking at the first sight. We no sooner begin to take interest in natural flight than the beauty and diversity of it are seen fourfold. The charm of it grows with the watching. Because we are earth-tied, the soaring 


\section{LIFE AND SPORT IN HAMPSHIRE}

of the sea-bird, the quiver of the kestrel, and the straight hard drive of the partridge are felt to be the most perfect of all animal feats. All that is athletic and all that is rsthetic in movement here combine.

The very magic of flight sometimes seems to me to sit and work in the tip of the wing. In proportion as the strong curved wing is lengthened and tapered to a fine tip, the flier has power over the air. In saying this I have not so much our wood and field birds in thought as those of the sea. For magic in the wing tip we should watch the soaring and sailing of the gull. By granite cliffs far west of the house in the woods I have watched the gulls flying across, or in the teeth of, half a gale. I think there well may be winds even in England against which every winged thing is powerless as if unwinged, but to overcome the gull entirely something like a hurricane must blow.

My eye is not educated nicely enough to detect fine shades of difference in air-ease as perhaps there are between our several species of familiar sea-gulls, such as the saddle-back and black-headed and lesser black-backed. I see, of course, that in the larger birds the time between the ordinary strokes or flaps is longer, the pulse of flight being with them quite heron-slow; but this is all the difference I do see between, say, a lesser black-backed gull and a blackheaded gull in flight; the ease in progress, commerce, 
or seeming kinship, with the air, otherwise appear to me not more in one gull than in another, and the style of motion identical.

Into the bosom of the wind a stream of gulls, large and small, continuous perhaps for several minutes, come across the tongue of land between the sea and its salt-scented pool up the estuary. Here, at the cliff, they meet the full force of the raving north wind, against which the starlings cannot prevail-at least, when starlings strive twenty times in the day to fly into it, I notice them buffeted back, as are the cliff-bred daws. Yet a stroke or two, and the gull shoots itself clean into the wind at this point, and rides there without the least sign of muscular strain ! It can advance leisurely for some little way in the teeth of this wind without a full flap of the wings. What distance it can travel without resorting again to obvious and ordinary effort I cannot determine; it may be fifty yards; it may be a hundred; precise measurement would be hard. Yet the impetus which the gull puts forth to shoot into the gale, and glide so many yards through it, is far from violent; a lazyseeming half flap or two serves the purpose. I notice nothing like the full flap which the wood-pigeon gives on starting in hot haste from the oak tree, a flap so impetuous that the wings smack each other smartly above the bird, and cause a loud sound.

But travelling across the wind-often more against than with-the gull can go forward hundreds of yards 


\section{LIFE AND SPORT IN HAMPSHIRE}

in the stormy heights without a flap, no matter how slight the initial impetus. How does it progress in such cases? Surely something more than that easygoing flap or two a hundred or two hundred yards back is keeping it up, driving it forward? Gulls thus making way against the wind look as if they were being drawn through the stormy air by unseen strings; only where and who is the wire-puller? They appear to be making no effort, or at most to be balancing in the high wind, swaying or rolling a little from side to side. This progress against the wind with no sign of effort really strikes us at times as a very miracle, contrary to all we know of the laws of motion.

But, looking intently at the gulls going forward into the wind, I think that, without glasses, we may usually detect what is not seen at a general and sweeping glance of admiration - that the tips of the wings every few seconds are very slightly stirred. This keeps the bird going. The stir of the wing tip is so trifling that it is only seen when carefully searched for. Either the air in turmoil must be exceedingly pliable and workable when a feather, stiff, yet elastic, is the implement brought to bear on it, or we may put all the credit of glorious achievement to the feather, assuming that it can triumph completely in spite of an unfavouring medium, the thin air.

I spoke of the gulls lying in the bosom of the wild north-wester. To see them there is to get the idea 
that they are at their absolute ease and comfort when they are facing and sliding into a wind that makes our ears and cheeks sting, a wind that far belowwhere it is not so strong-is whirling the sea-suds off the water and over the sand till they tremble into nothing. There are wild nights when the gulls will not sleep on the strand and come inland up the estuaries, but hard, unceasing winds in the daytime are rarely too much for a sea-bird's comfort. The rising gale might be his couch, he glides into it, lies on it so softly and quietly.

Turning from the wing tip to the body of a bird; we ought not to regard this as the flier's burden-a fact simple and sure, yet slowly borne in on us. We are led to argue from our own state-what a weary weight our bodies would be for a pair of feather wings to drag through space! Even through an element far more supporting than air, the body of the strongest swimmer, after a little splashing, must sink like lead, the limbs giving out from the deadweight, the effort to uphold it at the surface of the water and drive it along. So we are inclined to see the heavier birds' bodies in the same light, that is, burdens which can only be upheld and driven through space by matchless skill and power in the wings. It is true enough the wing is a matchless instrument. Compared with it, other limbs of motion and ways of motion by live things are of little beauty-even the dart of the fleetest fish in the stream. But in flight the wing 


\section{LIFE AND SPORT IN HAMPSHIRE}

does not do all. It has a partner in the body-a junior partner.

The frame of a bird in the air is a flying machine; and of this machine, though the wing is the mainspring, the body is yet a large and active part. Once we recognise this, we shall not slip into the old injustice of regarding the body as a mere weight to be carried through the air. There are many birds, small and large, whose flight can assure the watcher that the last light in which he should see the body is the light of a mere burden. To take a small and a large bird with different styles of flight; the chaffinch and the partridge alike tell us that the body is a most active agent in the work of flying. Some writers on flight have spoken of the body in its drop raising the wings, and the wings in their drop-or downward stroke-raising the body, as if we could easily see this in a flying bird. But $I$ doubt it. We know it must be so, but perhaps only in some of the largest and most easy-going fliers is this excellent exchange between body and wings made clear to the eye. I have not noticed it in the flight of any English bird, and am sure that no one would notice it with the naked eye in the flight of pigeon or partridge or smaller bird.

This work, then, of the body-raising the wings as it drops-is not clear to the eye: rather it is of the known but hidden mechanism of motion. What is clear to the eye is the great aid which the body brings 
to flight through its own weight and momentum. Once the pace has been gathered by the wing, the body comes into play. This is well shown in those constant intervals during the partridge's, chaffinch's, or woodpecker's flight when the wings are quite passive, shut. During the intervals the partridge is still moving quickly on its straight line, the woodpecker or chaffinch quickly through the second part of its arc or parabola; the machine is simply moving through the momentum of the body, the wings being out of play. Is not, then, the case just that of a train when the driver has shut off steam but not applied his brake, and the train is moving by the great momentum of its own body? When the chaffinch starts flying its wings are worked much harder than when it has been moving at a good pace for several minutes. Once launched and moving quickly, it describes through space arcs of some length, five or six yards. I believe that could we time a chaffinch or a woodpecker on a two mile journey at a good pace, we should find that the moments when the wings are acting are considerably less than the moments during which the wings are passive. It is because the body itself, thanks to shape, poise, and weight, can economise the strength of the wing that birds can live through great migrations. The flying machine can thus travel at high speed, hundreds of miles at a stretch, without failing; and if at length it does break down, the fault lies not in its mechanism, which is absolute 


\section{LIFE AND SPORT IN HAMPSHIRE}

in skill and finish, but because the bird is beaten by want of food.

I have taken the chaffinch and the partridge to illustrate the virtue of the body as parcel of this machine. But a dozen other instances occur to me. By our Hampshire coast I watched that noble sea fowl, the great black-backed gull, flying home from the mud flats in the very teeth of a hard wind. It flew as if there were no wind-stately, unembarrassed; and, powerful though the great slow-beating wings must be, I could not doubt that the heavy body slinging through the air was a strong support. The speedy guillemot, with a wing that looks more like a fin for the water than a sail for the air, tells me the same. Even the little hawk-moths, the sphinx moths, may depend for some of their speed on the body. We have to turn to the wizened bodies of feeble butterflies and flittering moths, such as "the carpets," to find fliers who seem to draw no aid from the body. An orange-tip butterfly's body cannot arail much-an orange-tip butterfly being chiefly wing; he is feeble in flight, without momentum: Still feebler, the wood-white butterfly has little control over the air-he is controlled by the airand can only flutter where he will when the breeze is light and kindly.

The bird's body and the hawk-moth's body-here is matter moulded to the very shape for flight, and for aid and relief of wings. But the wings which 


\section{A GIFT OF GOD}

poets and painters have attached to cupids and to angels - these would get little aid from their accompanying bodies. No, the human form does not lend itself to wings. For one thing, it is to-day not horizontal enough.

By the bird's tail Nature gave the finishing touch to flight. This made the masterpiece of motion. Losing many, even all, of those strong, bold quills that together form the fan of the tail, a bird can still in a fashion fly, can keep its balance aloft and steer its way. But the loss of this shapely, beautiful thing makes flight by comparison ungainly, a laboured effort; and it would make the greater journeys through space impossible. Who can picture the windhover hung in mid-air, safely anchored, without the aid of that winnowing fan, open to the utmost? or a tail-less eagle mounting, with rigid wing, its grand spiral staircase into the heights? Take in thought this fan from bird flight, and you throw back flight whole ages of creation. The part the fan plays, not in special air feats-as the hang and hover of the hawk and the soaring of the great sea fowl-but in the common forms of flight, is clear to me. The ringdove gives an easy illustration. When this dove is hovering hawk-like over his nesting-place in spring, his fan tail is open to the utmost, lying on and tremulously winnowing the air as the wings winnow it; but with, I suppose, this difference in motion-that, whereas the wings are in 


\section{LIFE AND SPORT IN HAMPSHIRE}

every full up-and-down stroke cutting simultaneously the double loop or figure-of-eight, the tail is going through a less complex figure. Whether this tail exercise, or quiver, is so simple as it might seemmerely a series of quick, short up-and-down strokes -is another thing. Probably some curve is even here made in each tiny stroke, so that, as with the wings, the up-and-down movements glide into each other without jerk or stop. But, however this may be, the tail, I imagine, need not be going through that double figure by which the wings uphold the bird and keep it fixed in the same point in space.

The beautiful discovery that the wings of bird and insect cut a figure-of-eight in space seems to have been made, independently, by both Pettigrew and Marey, an Englishman and a Frenchman. The complete figure-of-eight is only cut by the bird or insect when the body is stationary - a kestrel hovering over a point in the field, or one of the little sphinx moths whirring at its honey flower. One loop equalises-as it were defeats - the other, and hence the body of the flier is prevented from darting forward and onward. The eight is the anchor of the bird or insect hanging stationary in the air.

No sooner is motion forward and onward made than the figure-of-eight begins to lose its shape, and the bird henceforth progresses in what has been called the "waved track." As Pettigrew put it with 



\section{THE FIGURE OF EIGHT.}

\section{FIG. I}

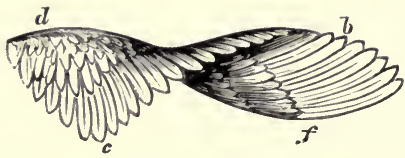

Fig. I, reproduced from J. Bell Pettigrew's "Animal Loconotion" (Kegan Paul, Trench \& Co., Ltd.), illustrates how the wing of a bird tends to be twisted upon itself. It is that of a red-legged partridge seen from behind and from beneath; $d$ and $f$ are the anterior margin of the wing, $c$ and $b$ are the posterior margin.

FIG. 2

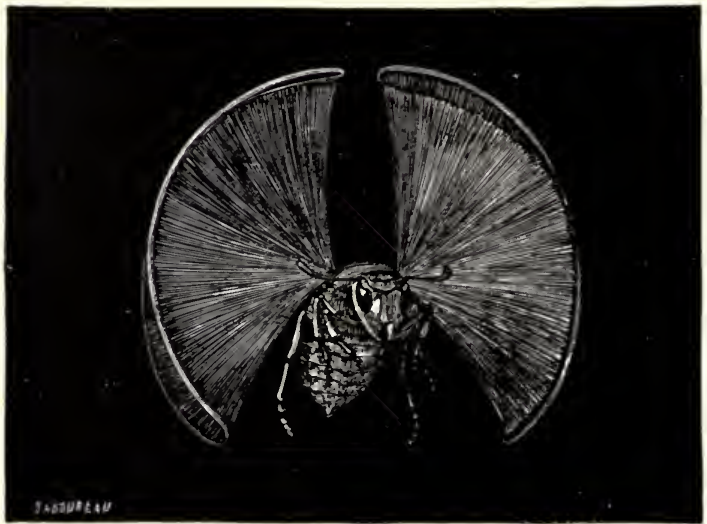

Fig. 2, reproduced from M. Marey's “Animal Mechanism" (Kegan Paul, Trench \& Co., Ltd.), illustrates the 8 which is described by the whirring wings of an insect hanging stationary in space. The extremity of each of the larger wings of the insect-a wasp-was gilded, and a ray of the sun cast upon it. 
delightful imagery, the eight is gradually "unravelled" as the flier advances.

How strictly, how neatly it is cut by a flier whose body is stationary and whose wings are in motion, an exquisite experiment showed; Marey was actually able to insert a pointed instrument in the middle of each circle or loop of the eight without its touching any part of the wing!

But though the tail may cut no figure-of-eight as do the wings, the more I notice the flight of birds, the more I am impressed by the part the tail must be playing. Sit under a tree into which a ringdove is carrying sticks for its nest or food for its young. Looking up at the flier, you notice how the fan of its tail is spread out so that each of the feathers is used to the utmost : every available bit of them is brought into play. There has been a tendency to treat the tail of the bird merely as the steering apparatus, the rudder; and even the chief authorities on flight seem hardly to have thought of it as auxiliary to the wings. A rudder it may be, but it is part of the sail area too. The instant a small bird springs from the ground the tail is opened and spread to catch and work upon the air. A small bird that has lost its tail rises on the wing with obvious difficulty. The tail seems to act on and work up the air, alike when the hawk is hovering and the house sparrow starting from the road; the instant the fan is opened, the sail spread, it finds some whiff of air to seize and use for flight. 


\section{LIFE AND SPORT IN HAMPSHIRE}

As the tail tells at the start, so it tells at the finish of a flight. When a bird is about to settle on the tree or the ground-especially, it has seemed to me, when it is hesitating - the tail is very active, stretched to its utmost. May it even be used on occasion for brake or buffer? May not the swifts that, a few summers since, I watched as, at high speed, they dashed to roost under the eaves, ${ }^{1}$ have been furnished with some means by which to stop suddenly against the brick wall, and yet not hurt themselves? I could hear the sound of stiff quills smartly brushed on the wall to which these roosting swifts rushed, but this, I think, came from the long, raking wings spread out. We know, however, that tails can at times be used for rude work; the woodpeckers and the nuthatch may almost sit on theirs, as they cling to the bark of the tree and pry into the cranny and hammer the touchwood. Thus, the tail might be strong enough for use as a break-speed.

For progress, then, the tail is always used at the start of a flight from the ground-whether the bird spring from the ground with its head pointing into or - a harder "take off"-turned from the wind; used with vigour when the bird is about to alight; used full-spread in the acts of hovering and soaring; in

1 Whilst we were staying at Leamington with a friend, the late Miss A. E. Darwin, one of the most delicate and beautiful characters I ever knew. Miss Darwin was grand-daughter of Erasmus Darwin, and a first-consin of Charles Darwin. She was a true naturalist; an evolutionist; an earnest believer in revealed religion. 


\section{A GIFT OF GOD}

full play, too, when the strong fliers are shooting or gliding forward with motionless, outstretched wings. But I think it is not much used by small birds, such as thrushes and finches, once well a-wing and engaged in longer flights; I often see the tail in these cases doing little or no work.

The tail is so made that, by its own trifling movements, it can work up the air for supporting purpose. But I have wondered whether the tail may not also be fed during flight by some of the air which the wings in their downward and forward strokes churn and leave in agitation. This agitation may not be all used up by the wing, and it must be considerable. Before I knew of Pettigrew's or Marey's theories and tests I wrote of every flying thing, from eagle to the gnat, as riding on a whirlwind of its own making, and I have found since that this is the exact imagery Pettigrew employed. In flights of a few yards, of a yard even, from branch to branch, some birds fan vigorously, tail full spread, and then the air the tail uses may well be that churned by the powerful wing strokes.

The flight of a quick, strong-winged bird through the air, or of a strong fish through the water, is a good example of the value for purpose of motion that exists in curves. Alike in the bird and the fish, what first appeals to the eye is the arrow straightness of line with which they drive through their element. Take a powerful swimmer, the trout, and 


\section{LIFE AND SPORT IN HAMPSHIRE}

a powerful flier, the partridge. Once started, they seem to drive clean and straight as a ruled line through the water and the air; and, if we knew or guessed nothing of the working of this machinery, the last thing we should suspect would be that this hard driving course in a straight line was achieved by a perpetual series of curves, an alternation of concave and convex, each beautifully rounded, and the hollow of one accurately corresponding with the hill of the other. Yet that is what occurs in the swift movement of the trout or the partridge. The impetus and the straightness so clear to the eye are only secured by their figure-of-eight or "waved track" action, regular as the strokes of the piston-in the trout by the body and tail, in the partridge by the wings-an action for the most part quite hidden from our view.

Perhaps in the trout this action is less obscure than in the partridge, for if we are behind the trout, at any rate, when it first starts, we may see that tail and part of body-the bending partare set to describe through the water an undulating track of concave and convex. At most, however, we are shown a sinuous line of snake-smooth curves. We cannot see that figure which Pettigrew taught us, I believe taught us rightly, to accept alike in the fish and the bird. In the partridge, whether at the start, the full flight, or the finish, we can see nothing of this action by curves. We only 


\section{A GIFT OF GOD}

know it. The partridge seems to travel dead straight, with no sign of that rise and drop which we notice in the flight of weaker birds, finches or woodpeckers, and the wings appear to whir simply up and down. The general impression is one of a straight movement forward, horizontally, of the body, and a straight vertical beat of the wings. The machinery -its surface at least-is there, acting in the open, yet it might be hidden absolutely from view for all we can see of its action by waved lines or curves, its figure-of-eight, or succession of loops, such as a figure skater cuts on the ice, swinging himself forward on the outside edge, and by each loop gathering the force to drive himself forward and cut the loop afresh.

As with the strong-flying bird, so with the strongflying insect. The hawk-moth must describe the waved track or loop running into loop, as the partridge does. There must be the concave and convex, the hollow and hill; yet all we see is the body plunging forward horizontally, and the wings whirring in a way that does not for a moment suggest that they are making a waved track through space. Only in large, easy-moving birds with a great wing area, elongated to a point-a gull, for instance-do we get by the naked eye any idea of the virtue of curves in flight; for here, though nothing can be really seen of the loop action, at least we can see distinctly in the outline and surface of the wing itself, the wave- 


\section{LIFE AND SPORT IN HAMPSHIRE}

like shape. Here is nothing flat or straight to the eye. The curve of the gull's wing is as remarkable as its taper.

By the curve and twist, then, of the flexible body and tail of the fish and the wings of the bird-the curve which is constantly describing an unseen series of loops or waves-strength and speed of motion can alone be secured. The virtue of the curve, its service in action, can hardly be put too high. Nor is it only used in Nature for rapid action in flying or darting creatures. We cannot notice the growth of plants of various kinds without being struck by the repetition of the curve and wavy line here too. The spiral growth of climbers is to the point. In the stems and tendrils of a thousand clambering plants appears the smooth, snaky line which we see in the action of a fish beginning to plunge swiftly through the water. In rest and in action equally, the curve has a great place in the system of Nature, in still life and in quick; and nothing is more remarkable about it than its smoothness and regularity, a bend in one direction always being compensated for by a bend in the other. It reminds me of that dualism of Nature on which Emerson dwelt in his noble essay "Compensation."

To see the cutting style of flight we have to leave the wood and visit the Hampshire islet in winter or early spring where the little waders gather. Here springing from the beach, a flock of a hundred dunlins 
will hang in the wind for a few seconds in a compact mass ten yards from the ground. Then the flock narrows into a long streamer, coiling in a beautiful wavy line through the sky. During this opening out the birds move slowly. Then they appear to stop dead for a moment or two-every dunlin simultaneously. They draw together next moment into a bunch as before, and suddenly, with tremendous speed, cut down, almost striking the pebbles; but, eddying, swirling, they cut up again, hang in the wind, and slowly serpentine out into the wavy line.

Presently, after this figure has been cut and re-cut just above the beach, the dunlins leave the shore and dash out to sea. There they will cut and glance, and hang and ribbon and mass just as they have been doing over the land.

And they will sheet themselves, these wondrous birds, and, dropping low, dash a hundred yards into the wind, moving all the while only just above the white-tipped waves!

Whilst swiftly serpentining thus over the sea, their bodies and wings must all but brush the water, yet they seem never quite to touch it; to fly swiftly at a dead level is as easy to the dunlins as any of their wing feats. Not a bird need wet a feather, though only a few inches divide the flock from the sea over which it is dashing and swerving at such a high pace. Fisher-folk have told me tales of the baffling of the sparrowhawk by the dunlin or sander- 


\section{LIFE AND SPORT IN HAMPSHIRE}

ling; of how the bird of prey is sometimes beaten after a great contest of speed and a ravening chase over land and water; and, watching these exercises of dunlins in a high wind, I do not doubt the grim hawk can be outclassed by these delicate little waders. The sparrowhawk and the merlin are the deadliest foes of the waders and the wild ducks. Morning after morning I have seen a hawk working the shore in search for prey; always the same beat at the same hour. Teal and mallard, wallowing at the foamy edge of the sea or just floating in the shallow lakes made by the incoming tide, well know the danger, though the hawk be gliding a full hundred yards away by the side of the cliffs; and they will be up and off to the deeper sea if the enemy turn a few yards in their direction. A hawk, I believe, will keep the dunlin flock in the same state of unrest.

Without any of the quick-changing effects of sun and shade playing in turn on their spread wings, the dunlins during this drill are very good to watch; but the play of light does enhance the beauty of the thing. When I am looking due south into the light, the flock springing from the pebbled strand is but a thick shower of dark, almost black, marks in the air. Suddenly the flock swerves, and the shower of dark is a shower of light-only to become dark again next moment. How white the dunlins can look in repose as well as a-wing we recognise when, with our backs to the sun, we look at a flock 


\section{A GIFT OF GOD}

of a hundred birds sprinkled on a little tongue of sand or gravel which the outgoing tide has left dry in the harbour. I have seen them look as white as gulls or as the terns, swallows of the sea, two of which, a month ere their season, visited the dunlins' haunt at Hayling during a gale.

I shall have something to say of the unanimity and simultaneity that live in the movements of bird flocks and adventures. In none do they live more wondrously than in this drill of dunlins. Here is a leaderless regiment which works together with a precision and order that surpass all human achievement of the kind.

The absolute rhythm of motion is in this dunlin drill. There is no jangling note: never a wing among those hundreds of wings is awry. Every wing swerves in the same second, every wing cuts down or up in the same second.

Only when the slow, wavy streamer has grown to an unmanageable length will the flock break for a little while into two distinct parts; but this is carried out with such order and accord that the rhythm of the dunlin motion does not seem affected by it. How is this rhythm secured, this faultless time kept, though no timekeeper is in the flock? If the movements through which the dunlins go were always the same -each exercise, from the moment of springing up to that of settling on the ground, but a repetition of the preceding movement-we might understand it 
better. But it is not so. One movement lasts longer than another: one takes the birds out to sea: another keeps them inland, and so on. The number of swerves, the length of the streamer of dunlins, these, constantly varying, are not fixed or preconcerted. There is a cause for each dunlin variation, as for everything conceivable; but this does not help uswho in the mass can do so little without leadership and preconcert-to understand how the rhythm of these exercises never goes wrong. Mr. Ernest Hart, the Christchurch naturalist, was taking some photographs for me near Hengistbury Head when he saw a large gathering of the waders-dunlins and ringed plovers, with a fow curlew-sandpipers and stints. On the wing they were "turning, twisting, rising like a spiral column, the glint of sunlight on their white breasts," but darkening as the curves reached the higher ones, and ending in apparent black. It was, he told me, one of the most lovely sights of wing evolution he ever witnessed. "They were reluctant to leave just the spot we invaded, and, like sand-martins going to roost, kept wheeling round and round all the time we were there."

For miracles of motion we need not turn to distant spheres. Miracles are always near home. They lie beneath the surface of seeming simplicity in the flight of almost any quick-winged bee or fly.

The insect makes progress forward or sideway through the same principle that is working in a bird 
-by a series of beautiful loops, thanks to the friendly opposition of the air acting on a surface that is so resilient. One has only to touch the wing of a dragonfly to recognise this quality-so easy to bend, so quick, when let go, to spring back to its rigid position.

So far the workings of the insect wing and the bird wing are analogous, even identical. But the insect needs to fly, if, as a rule, not so far, at least as fast as the bird. I say, " as a rule not so far," for we associate the great migrations chiefly with birds; though now and then the insects in their millions will start on these travels too, and move as quickly and far as their feathered companions. However, for their short everyday journeys they need swift motion; how can this be accomplished by such small wings as most of them have?

True, the small wings have a weight correspondingly small to carry through space. But this is deceptive, and does not really explain how it is they can make as rapid progress as a bird that carries a weight far heavier; for the weight is actually not more an impediment to a bird driving through the air than to an iron battleship driving through the water. Weight is so finely poised, presented to the opposing and sustaining element-the air is both-with such adroitness of shape, that it tells no more against the bird than against the battleship.

Thus the bee has not an advantage over the bird 


\section{LIFE AND SPORT IN HAMPSHIRE}

through the lesser burden to be carried in the air; and the bird surely should have an advantage over the insect through the greater length and strength of its wings, the most powerful and long fliers among birds being those with long wings. The truth clearly is this - the bee and fly would be easily outpaced by any quick-flying bird were it not for the amazingly short time they take to accomplish a full stroke of the wing.

A thought of the camera, perhaps, with its instantaneous shutter, may help to give an idea of the insect's swiftness in accomplishing one stroke and beginning and ending the next. In photography we talk of an exposure of the sixtieth of a second. But if a bee were as slow as this in completing her stroke, her honeycombs would take long in the filling. She has to fly far afield sometimes to reach the glorious sheets of sainfoin or heather, perhaps two miles; indeed, some bee-masters think she will roam farther than this for her stores. The bee is by no means the quickest of insects to complete her wing stroke-the common house fly is almost as quick again-but she is more than three times as quick as an instantaneous shutter which gives the sixtieth of a second exposure.

In one second her wing completes a hundred and ninety strokes. Are the stars more wonderful than this?

Marey long ago proved these figures of miracle motion by a series of trials, exquisite and simple. All 
he needed was a little revolving cylinder with a sheet of thin paper stretched tight and smooth upon it, and blacked by the smoke of lamp or candle. The cylinder was made to turn on itself at a fixed rate each second of time. By a delicate forceps, he held the insect so that the tips of its wings, as it whirred them, just touched the smoked paper. Each touch represented a wing stroke, and, counting the rows of white specks on the lamp-black after the experiment, he found one hundred and ninety for each second of bee whir, and nearly double as many for each second of whir by the house fly. If his figures sinned, they sinned in understating the number of beats of the insect wing to each second-for the brushing of the wing tip against the cylinder, light though that brush might be, would, if anything, lessen the pace.

Only one objection, I think, could be made to the experiment; it might be suggested that the whirring of the insect held by the forceps did not represent full strokes. But those who have gently held prisoner between thumb and first finger a whirring moth will not be impressed by the objection. They will feel sure that, had the moth been released, it would instantly have darted forward into space with no more exertion than it was exercising as a prisoner between the fingers. Small wonder, then, that when even the humming-bird hawk-moth is whirring over the flowers or darting from bed to bed I only see a mist of wings. This moth having much longer and more powerful 


\section{LIFE AND SPORT IN HAMPSHIRE}

wings than the honey bee or syrphus, the hoverer fly (whose strokes to a second Marey, I think, did not count) need not whir them so quickly to reach a high speed; still, with seventy or so full strokes in each second, its machinery of motion is wondrous enough. With such a white-hot whir, we may wonder how the insect wings do not kindle heat, set themselves aflame, and shrivel into nothing.

Figures of miracle motion like these we can add up, estimate to a nicety, as we can weigh a planet. Here we end ; we cannot really grasp and understand them; they verge on, if strictly they do not belong to, infinity. But theirs is an enchantment which some great confounding things of infinity may be without-they relate to such an exquisite tiny machinery of perfection; a machinery of inuscle to put us out of love with the coarse hair-springs and the great, clumsy cog-wheels of some gemmed and costly watch, a thing that at most can chronicle large fractions of a second.

The humming-bird hawk, the day-flying sphinx moth of our gardens, is a little flier I have always watched with delight. Though my charming little friend will sometimes fly on summer evenings about sundown, I always imagined it a worshipper of bright hours and warmth. I thought it a sound sleeper, like a butterfly, during rude weather. Yet once I have seen it on the wing brisk as could be on a dark, rough autumn day! It zigzagged from blossom to blossom-red and pink geraniums-and, buffeted 
by the wind and beaten on by the rain, still held itself aloft, and plunged trunk into the nectaries, seeking their sweetmeats. Sometimes the wind would toss it from the blossom ere it could poise close enough to plunge trunk down nectary; but beaten once or twice, it would return, and in the end succeed.

Whilst this moth hovers, the wings appear to whir not at right angles to its body: I should say they may be at an angle of forty-five degrees or so, and away from the head. Often, whilst drawing the sweets from a blossom, the insect is hung in the air, touching nothing with its legs, which are laid back close to the body, like those of a sea-gull in flight. But, look very closely, and you will see that now and then when the hawk-moth appears to be hanging in the air it is really resting - so lightly as not to crumple a petal! -on the flower with its thin, little grey legs. Yet, resting so, it keeps whirring its wings as if it were hanging without support. One thing I notice in my sphinx which shows it not infallible of eye. It will sometimes visit dead blossoms of plants round which it is hovering. True, it discovers instantly that they are dead, and in a flash is at a fresh flower! Still, were its sight extremely powerful, would it waste one beat of a lightning wing on a visit of inquiry to a flower spent and almost colourless? The sphinx is not the only sweet-seeker that makes a momentary mistake like this. The humble-bee has an eye for colour, but has it an eye for form? It came to the 
handle of my garden roller when this was new and painted with gaudy colours. It mistook these rings of coarse colour for blossoms-to which they bore little likeness. The bee or butterfly appears to be only infallible of eye whilst it is very close to the object. At a little distance, perhaps, it sees just a blob of colour; it must come very near to make out the exact form and texture of the thing observed. To read the flowers aright, it must have its face pressed close to the petals, as a short-sighted man must have his face pressed to the book. Once at close quarters, however, the insect sight is very powerful; it has every detail under microscope.

Another thing about the little sphinx moth is the quickness with which it discovers whether a blossom has honey or not, when it is up to the flower and poised. That fine feeler, the trunk, is out in the flash of a second if there be no honey. How does the sphinx carry its trunk when it is honey-seeking and roving from blossom to blossom? Well, when the flowers are very close together, when they belong to one bed or patch, the sphinx does not neatly roll up the trunk and pack it away. Nor is the trunk carried about quite unrolled. A sort of compromise is convenient. The trunk is kept out, quite loosely rolled up. Thus it does not hinder the movements of the moth, and it is ready to straighten out and plunge into the nectary of the flower.

Diversity in the style of insect-flight is at least as 
great as in the style of bird-flight. With birds, the wing stroke is up-and-down vertical action; in many insects the stroke more resembles a backward and forward stroke, horizontal action. Thus the wings of the two-winged flies are set more for the horizontal than for the vertical way of striking the air; so that the figure-of-eight cut by the hovering sphinx moth lies, as it were, flat on the air, whereas that of the hovering hawk stands upright. But these contrasts in style of wing action we know rather through experiment than eyesight. There are variations and contrasts much more obvious. Three butterflies which are out in full summer show three widely different styles in flight. The large and small skipper butterflies have a darting, very impulsive way of flight. A stroke carries them straight and clean through the air for a yard or two, when they zigzag off at a tangent. The white admiral butterfly has a wholly different style. Its movements on the wing are serene, smooth, gliding. Here is consummate grace. Third, that humble flier, the meadow-brown. It tosses itself about, a single bobbing or jerking of the feeble wings hardly carrying it a whole inch. The meadow-brown's seems about the least effectual form of butterfly flight; and with the meadow-brown we may group the small and larger heath, the ringlet, and a few others; but on a fine, still day these feeble fliers will keep a-wing for hours with only short resting spaces. They are not so ineffectual as they look. 
What a contrast between these butterflies and syrphus, the hovering fly of summer! In the hot sun, among the bushes, syrphus hovers and darts for hours. It gives one the idea of a fierce, waspish, little thing, living its life at white heat. This is because of its tremendous activity, and the earnestness it seems to put into each movement. The hovering habit syrphus shares with many creatures, but its darting, jerking movements are more peculiar. After spinning for some seconds, perhaps a quarter of a minute, at one spot, syrphus will flash away two or three yards, to take up a fresh position. It rarely goes straight to the new spot, but takes a zigzag course, not unlike the lines on a weather chart. When first I noticed this darting of syrphus I thought it must invariably be done in the pursuit and capture of prey, or that the object was to assault and drive away a rival; but, though these fast and furious movements seem to disturb, if not dismay, other insects occupying the same yard or two of space, I doubt now whether syrphus is always hunting for prey or love. Syrphus settles on a leaf from time to time, but it can keep up the exercise for an astonishingly long time. This is a strenuous life indeed.

One little feature of syrphus movement I have noticed-the ease and frequency with which, whilst hanging in the air, the fly can turn half or quite round. One moment I and syrphus face each other, 
the next he has turned his tail to me; and the revolution is not always so quick but one can see it effected.

What a change from the bob of meadow-brown to the skim and whir of dragon-fly! For absence of effort the flight of some dragon-flies does not compare ill with that of the kestrel in still air or light breeze. There is the red-bodied Sympetrum striolatum, which flies in numbers by the Hampshire Loddon in September. It belongs to the whirring class of insect fliers. It is carried forward, jerked at a tangent when and whither it will, by a machine-like vibration. Perhaps one should not use the word "stroke" of the wing action of sympetrum or these other lightning fliers. It seems clumsy, as if one spoke of a molecule as a clod. Stroke carries with it the idea of some deliberation, of action that more or less can be followed by the eye. Between two strokes, however quickly delivered, there is a gap we can be conscious of. There is no gap measurable by our minds between the whirs that together form the flight of sympetrum.

In some of the electric machine sheds at ironworks, where water is forced up to cool the outer walls of the furnaces, we may see steel rods revolving at such a pace that they do not appear to be in motion until we look at them rather closely. I have noticed this at the great Staveley Works in Derbyshire. The smoothness of the motion and its speed make the revolving steel rod look as if it were not at the moment 


\section{LIFE AND SPORT IN HAMPSHIRE}

in use. No flying creature has, in its wing action, reached this point. The machinery of motion in the flier is masked for the most part, but there is not this optical delusion for us about it. A shiver, a glistening of the wings of sympetrum, or of the sphinx moth over the flower, show clearly enough that the machine is in use. And the same may be said of syrphus. But the wing action at its intensest seems to come within imaginable distance of this still-looking motion in the steel hand or rod revolving.

This I notice about the whirring dragon-fliesquickly as they can move from spot to spot, such quickness does not correspond with the pace at which the wings are going; say sympetrum can move over short distances at a mile a minute; even so, this speed does not strike one as very high, considering the intense vibration of the wings. Sympetrum rests with wings spread out and flat. It always looks as if it were on the point of taking to flight. This resting attitude is common to the swift insects of the order. Feebler fliers, such as the demoiselle, or puella, the "little girl," whilst at rest, fold their wings over their backs like a sleeping butterfly.

But for a sort of jugglery of flight, not a bird nor an insect, but a bat, I think, comes first. There is one of the larger bats whose exercises on a July evening at sundown are almost painful to watch-at least after the eye has strained to follow them closely for a few minutes it desires a little respite. This bat I took at 
first for altivolens, the noctule; but, whilst I watched him, he was quite a low flier, and he seemed to be a little smaller and more agile than a noctule. Perhaps he is Daubenton's bat, which, I believe, I have seen hawking over the Test, whilst I have been fishing for the great trout in the glorious pool at Kimbridge; or he may be a scarcer species. This bat is not matchless for straightforward speed on the wing. He seems no quicker than the little pipistrelle bat, and is quite without the splendid sweep and cut of the swiftwhich, at a few minutes before nine o'clock at summer's height has scarcely rushed to roost ere the bat comes forth from roost.

$\mathrm{He}$ does not curve and glide with the swift's stateliness; rather, he flips to and fro by a number of small, quick wing strokes. It is not here that his flight is wonderful or worth special mention, but in his dives and tumbles and glances to one side and the other, and his thrusts upward. The quickness and suddenness with which he makes these movements are amazing. When $I$ am near enough, and the air is dead calm, often a tiny snapping or clicking sound tells me that one of these movements has given the bat an insect. Probably the prey is rarely missed. No bird movement on the wing is quite like this of the bat. Swift and sand-martin take their food at a high speed, but they do not twist and jerk and somersault upon it like this bat; they rush upon it, rise or drop to it, or swerve at it with more even, 
gradual action. The bat is all angles in the act of seizure. Apparently he does not see the insect till he is all but past it; and then, with incredible power to stop his straightforward flight-incredible, although seen-hurls himself at it, to right or left, or straight up or straight down.

The flycatcher and the wagtails, quick as they are with their sudden, very pretty, little glancings and twists in pursuit of an insect, do not touch the bat in this; the only wing exercise of a bird that to me resembles it is one we sometimes see when two fiery finches are playing at chaser and chased. With the birds, however, it is merely blind flight. No accuracy is aimed at by the pursued, and again and again the pursuer overshoots the mark, even if in the end he succeed. But with the juggler bat is this deadly precision-he takes an insect, depend upon it, in each of those abrupt feats.

For all our wonder at the bats, we cannot be friends with them-dirae obscenae volucres. A fow, I know, do handle a bat without discomfort, feed him as they feed a pet, get to terms with him. But, for most of us, the bat lives and moves only in the half-light of things eerie, remote; things that scarcely seem to belong to our kind, familiar earth. With his monstrous sleeps, with his membrane wings, fingered and clawed, there is something that affronts us in the bat. He is harpy of an hour full of fancies, fantastic figure of a world neither day nor night. 


\section{CHAPTER III}

\section{THE SINGERS}

THE song thrush is the most essential bird in England. Would it be absolute England, could there be a full and typical English wood, without the thrush? The oak, the chalk, the Saxon throstle-these seem to me the most English things the mind can picture, no matter how common they may be off English soil; and to them I can add the elm, whether it be native tree or not. The elm is indispensable to our southcountry landscape-to the tangled and deep-rutted lanes and the thatched hamlets and early English spires, the cressy, trout-brooks and old mill-dams; and in the elm we ever set a singing thrush in our reveries of strong and delicate English scenery. I believe that the two most familiar and constant and most delightful sensations that come to me through things of Nature are seeing and fingering the first song thrush eggs of the season where they lie in their cup of moss and clay, and hearing the first note of the thrush in autumn, when it begins once more its lay. These things have a wonderful curing and refreshing effect on the spirit. I have thought of them at night sometimes when lying painfully 


\section{LIFE AND SPORT IN HAMPSHIRE}

awake, and if they will not compose the mind for sleep, I know of nothing in Nature that can do so.

Equal, perhaps, to the pleasure of hearing the first October thrush is the pleasure of seeing him in the act of song. In the dark yew tree, dotted with scarlet, I saw the speckled throat of a thrush in song. This makes a lovely picture of bird, fruit, and tree. But, so far, the song is a preface; just a little piping. Not one of the bold, distinctive thrush phrases lives in it, or will for many weeks to come. Looking at the thrush in the grand gloom of the yew, at first I only recognise for sure it is this particular thrush that is singing by the direction the sound travels; it is several seconds before I can detect the slight movements of the throat, the ruffling of the feathers there; the thrush does not yet throw up its head, put its soul into song. With the skylark it is otherwise. Early in October, when thrushes are piping faintly between gusty storms, larks will fight and sing as if it were spring. They choose the dullest, the wettest days of the early autumn, what we should call foul weather. True, instead of a dozen larks singing over a large field, there may be only two or three, but these will shrill with something of the fervour of larks in May.

The more we notice the singing of birds out of the mating and nesting time, the more baffling does the thing grow. Now it seems as if soft, bright weather were the chief incentive to bird song in 
autumn and winter; presently, as if the best music days were dark and rainy, not, perhaps, days of a steady, dull downpour, but wild and gusty with bursts of rain that make puddles everywhere"cluttery weather" I have heard my friend the gamekeeper call this when it comes in spring. And so one may alternate between a thought that bright weather, not dull, makes the birds sing, and a thought that dull weather, not bright, has this effect.

Starlings sing longer and with more spirit in what -to our sense-is delicious autumn and winter weather than when it is dull and wet; though they will also sing a little on soaking mornings-sing as they shake the wet from their breasts and wings. The missel thrush, I think, prefers for his winter songs the soft and sunny days, though in the spring he trolls out a brave song on the stormy days. Larks and song thrushes are much harder to decide about. How they seem to revel in such bright autumn weather as we revel in! Yes, but at other times, how they seem to revel in days the exact reverse. Do brilliant days with clear, mild air set them singing? Often so. But it may happen that the larks begin in earnest and many song thrushes strike up on an autumn morning when the sky has a roof of lead and the whole day drips.

Burning heat and bitter cold are more certain in their effect: most English birds are songless then; the ringdove and the turtle-dove in the heats of July and 
August, the wren and the gold crest in the frost and snow of midwinter, are among the very few songsters. There is no mistaking the effect of hot summer weather on birds; a single burning day stills them.

The thrush has only to sing strong and bold at two or three wintry dawns to persuade us he is the best English songster. Taking the whole year, I doubt whether he has an equal, and with his notes fresh in my ear, I am sure he has no superior. The wren, the starling, and the redbreast sing as many months as the thrush; they sing as many days; the wren and the redbreast, though not the starling, sing as late in the evening; and the redbreast, if not the wren and the starling, will sing as soon in the morning as the thrush. So, for early song and late, and for song on many days, the thrush has his compeers. In quantity alone he is not at the top of the tree-at least he only shares it with these others. But when it comes to quantity and quality together, shall we not declare the thrush peerless? Waking early and listening to him at successive dawns, my feeling is that he is the best of singing birds. Granted others-blackbirds and nightingales and blackcaps - are choicer, they hardly vie with the thrush when we consider the year of song as a whole. After all has been said in praise of quality, quantity does count; especially where, as in the song of thrushes, it is not discounted by absence of the other merit.

The pleasure we have in hearing a song thrush 



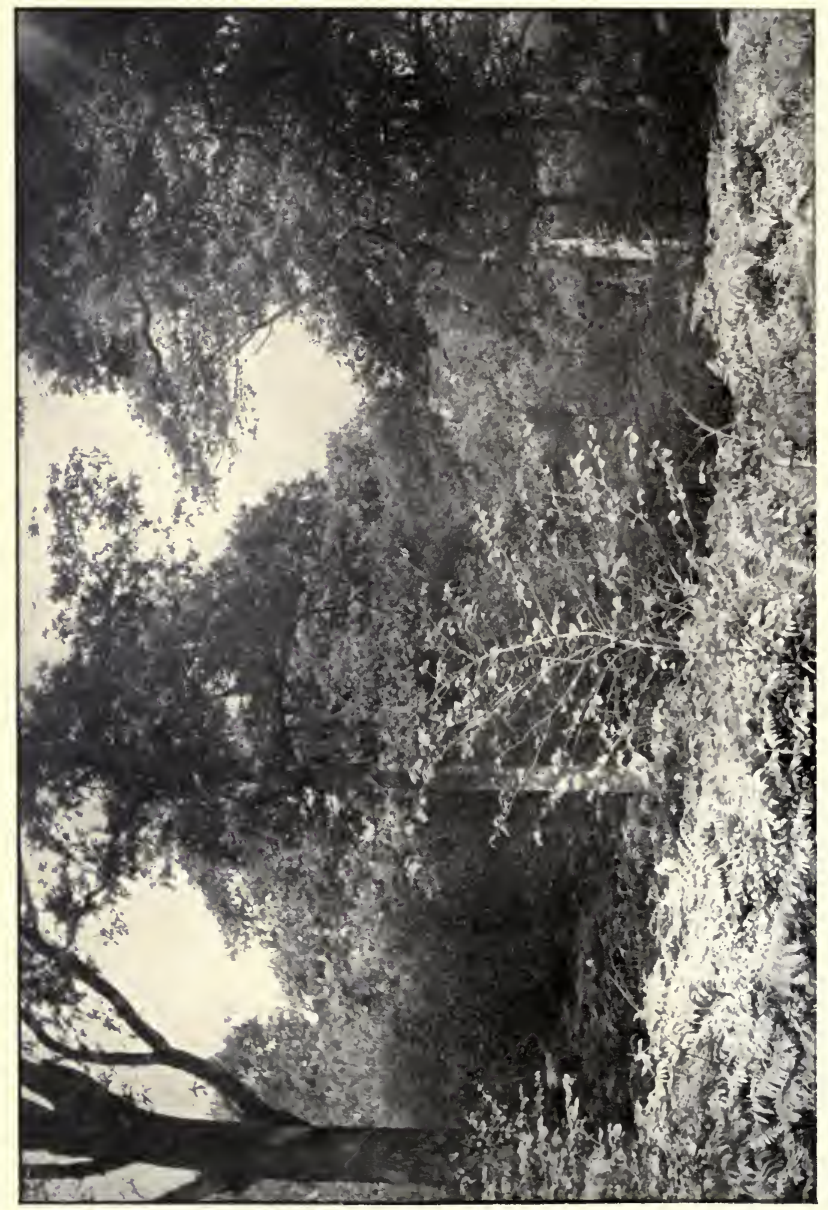

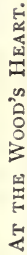


singing from a tree just outside the window in the half-light of a winter morning cannot be told in words. The language of pleasure is never, I think, more inarticulate than when it tries to put into words the impression which these common things of Nature make upon us. We say a pudding is "nice," or a room pretty, or the play good, and there is an end of it; the epithet has served; it leaves no sense of a gap or woeful failure to tell how these things touch us. But a thrush's ringing notes at dawn, or the sappy coppice in April with a blue and green ground of byacinth and dog mercury, or the first sight of the orange-tip butterfly - these pleasures seem to get into the blood and brain. Simple, innocent pleasures we say they are; innocent, yes, but $I$ am not sure of their simplicity: if so simple, why should it be hard to analyse the pleasure they give, and impossible to express that pleasure in words? This points to complexity rather than to simplicity. Perhaps there is a kindred emotion, but rarer and, I think, inferior, about certain things in art-about a picture of Millet or Mason, or about the fine arrangement of a few words in literature. A friend, not at all given to ecstasies, has told me of lines in Shakespeare which almost bring tears to his eyes, though the passages in which they occur are not what we call pathetic. There are lines in Wordsworth which have a similar effect. I cannot read the line or two in Wordsworth's poem on Fox, which describes how the Vale is loud 


\section{LIFE AND SPORT IN HAMPSHIRE}

and the Voice is up, without being stirred. It is as if there were some subtle virtue in these things entering us through hidden doors. We cannot lay hold of them and write them down or say them; they are volatile and elusive. So I doubt whether the charm of this speckly thrush loudly singing in the beech tree at dawn is so simple as at first thought it may seem. But we can note an impression or two the song makes on us. These liquid sounds are perfectly attuned to the unworn day; they put a finishing touch of freshness to the hour which is everything that is fresh. Wintry dawns, when the thrush sings so bold and loud, often break through a very grey sky, whilst at intervals the pane is streaming. Open the window between blustery showers, and there is nothing in the feel of the air or the look of the dun earth to distinguish the winter from some mild March morning.

In February, I think, the thrush begins to get his "peebur" note. Of song thrush phrases, this one of the three peeburs is the most familiar, and, at its perfection in spring and summer, the choicest. After the three peeburs, to me the most familiar thrush phrase is that one which sounds like "pettybird, petty-bird, petty-bird," or "pretty-bird, prettybird, pretty-bird," uttered, I think, quicker, and for sweetness of tone not so remarkable.

The pure and most beautiful peebur passage in the thrush's song is not taken up by the starlings 
in my garden. Starlings do now and then pick a few bars out of the thrush's song and perform these finely; but their usual medley, full of entrancing little clicks and shakes and softest chatterings, does not seem to me to owe much to the song thrush, or to any other constant singing-bird. Notes it contains that closely resemble those of daw and rook-the daw note is particularly common in the starling's song-but I feel that too much is made of the plagiarism of the starling. Even insist that he does absorb the cries and phrases of half-a-dozen or more wild birds: his song as a whole is yet original. The starling's poetry is like Tennyson'sthere is hardly a striking passage in one or the other which, to some critical ear or memory, is not borrowed. Yet, when all has been said about this, the strong feeling is with one that the poetry of both is their own.

What is true of starling is true of sedge-warbler. Mr. Witchell himself did not convince me that the sedge-warbler is the mere mimic it is supposed to be. He made a table of statistios on sedge-warbler song. He listened to fourteen sedge-warblers, which, he believed, imitated, more or less exactly, the striking notes of sparrow, wren, chaffinch, swallow, and other common English birds. He repeatedly heard the sparrows' "chissick" and the sparrows' "tell tell," the chaffinches' "pink" ${ }^{1}$ or "spink." Eleven

1 I have just heard the spring "pink, pink" of the chaffinch in a London street, a delightful experience-March 26, 1908. 


\section{LIFE AND SPORT IN HAMPSHIRE}

of the fourteen sedge-warblers cried "chissick," and almost as many "tell tell": in fact, he heard in all thirty-four "tell tells" and thirty-one "chissicks." This he told us in his "Evolution of Bird-Song."

For my part, I doubt whether I ever heard of sedge-warbler-and I have listened to the bird summer day after summer day whilst angling, and sometimes on a dark June night, too - which did not utter the "pink," the "chissick," the "tell tell." If ever we made the house sparrow rare in England, the sedge-warblers in the river tangle would none the less cry "tell tell," "pink," and "chissick." These sounds, whatever their origin, are as much a part of his song as the passage sounding like "swot, swot, swotty" is of the nightingale's. Let the sparrow become as extinct as the auk-the notes supposed to be his would be safe in the keeping of the sedge-warbler.

The thrush, though singing everywhere in April days, is not yet at his height of song. For the set and finished phrases, perfectly enunciated, we must wait till May, even early June perhaps. The thrush is at the prime with the year at the prime. It is as though the days and long evenings, full of sap and scent, were needed to inspire him to the utmost of his strength as singer. But in April we can realise the range and rank of the song thrush through the missel thrush. On a chilly April evening, a still evening, the missel thrush will settle on the top twig of a high oak for twenty minutes or half-an-hour of earnest song. He 
has not sung many minutes ere the song thrush takes a high twig on a neighbouring oak or fir, and the musical duel begins. Now is the time, without depreciating the missel, to appreciate the song thrush. Say the song thrush is-for a song thrush-an average performer; and the missel thrush at the top of his strength-if missel thrushes vary distinctly in song strength. Listening to these rivals, it seems to me that individual notes of the missel are as pure and good as individual notes of the song thrush. I cannot give the missel thrush notes a name, or syllable them, but all who know the missel thrush can agree that it has some good notes. Also the missel thrush is free from harsh, clattering passages which to our ear are quite without beauty of sound. Such clattering, dinning passages are rarely absent from the song thrush's lay; they seem notes of anger or agitation put to musical purpose. The blackbird-as if more fastidious in song-never, I think, uses any of his chink or cackle for song, nor does the missel thrush bring in his jar or rattle.

Here, then, missel thrush compares well with song thrush; he has individual notes as good, and he has no harsh passages. But all the rest is with the song thrush. The missel thrush's lay is a series of little jumbled passages, each lasting three or four seconds. To my ear, one passage is quite like another. The song cannot be syllabled, and nothing is very definite about it. No distinctive melody or tune runs through 


\section{LIFE AND SPORT IN HAMPSHIRE}

it. There are no striking variations, if now and then there are low undernotes. It is just a wood-wild, bold carol, with associations and surroundings that delight us.

But the song thrush has class. Here is something that reminds us of the high training in science, the painstaking practice of a master. The song thrush is the professional-the missel the amateur. The song thrush has so much more than sweetness. He has brilliant execution. Order, method, variation are in his definite, clear-cut phrases. Even about some of the less melodious expressions there is a suggestion of polish and cultivation that alone would set the song thrush near the top of the tree. Thus through a week I have listened to a thrush pronouncing " chiko, chiko, chiko" quickly, sharply, and so clearly that I can easily syllable the passage. Not a very pretty phrase it looks on paper, and in truth is not very melodious in the singing. Yet there is class in this, as in every other clear, orderly phrase of the song thrush. And presently, when the practised thrush perfects his famous "peebur, peebur, peebur" phrase, we have beautiful melody added to masterly execution.

Song thrush duels in spring, like those of skylarks, are fiery and short; but we may go into the fields and see scores of encounters between skylarks to a single one between song thrushes; a thrush duel is not to be seen every day, even at this season, when 
the birds are full of ardour and jealous anger. When once rival thrushes, male birds probably-though the females can fight too, I doubt not-fall out seriously, they may meet and fight several times a day. The song thrush, though it can be tamed and persuaded to come indoors and take food from the table, is naturally a deeply suspicious bird, like the redwing. It can hardly take two pecks at a worm on a grass plot, or strike its snail twice on the highway, without glancing about warily. Thus, thrushes will often stop their duelling to look around, as if fearful of other and more dangerous foes. We must keep very still when close to thrushes fighting. The duellists stand and face each other, about a yard apart, quite still for a quarter of a minute, or so; then, as if impelled at the same second by the same agency, both spring into the air a foot or two; their heads, or at least their beaks, touch, and there are sharp clicking sounds that can be heard twenty yards away. Each spring and assault is quickly over, and between the rounds the fighters face each other, watchful, vengeful. Nothing seems to come of these duels. After a few rounds, they exchange fight for food; perhaps, at the very moment a spring seems imminent, a morsel of food is seen by one of the birds, and the fight is done.

But in the spring I have seen a curious, cruellooking form of fight between two song thrushes. It was on short grass. The birds, instead of standing 


\section{LIFE AND SPORT IN HAMPSHIRE}

up and facing each other, before the spring and the click of the beaks crouched down and stretched their necks in a wicked way along the grass. The attitude was snake-like; it gave me the idea more of reptiles than of birds at war. The clicking sound is not always the result of a blow; the thrushes in this duel made the sound as they flew down to fight; and then it must have been from the savage snapping of the beaks.

These song thrush duels begin at the time when the fire of life burns at its brightest in our birds. How it burns in the chaffinch! By the opening of May the cock chaffinch has reached, I think, his prime of polish. Bullfinches, plump and boldly coloured, and goldfinches, so delicately built-brought to the fairest finish of shape-are more effective at a glance than the chaffinch. But we do not notice them in their wild state waxing and waxing in colour and shine, as we notice the chaffinch. The winter bullfinch-a warming sight in the bare thorn hedges of the lane at the edge of the wood-is as good to look at as the May bullfinch; we see the same smoke-grey mantle, the splendid contrasts of pure white and blue black, whilst the red of December with the bullinch is very much the red of May. But for two or three months, February, March, and April, there is the roadside chaffinch-the bird of the country roadside in England-growing more and more burnished. Finally, in May, what a burning 
bit of life he is! It is hardly possible to give his colours; they are not contrasted or sharply defined, as those of bullfinch or goldfinch, they blend into each other; but I know that the polished blue and grey about the crown and the back of the neck, and the darker blue of the bill, and the chestnut brown of the under parts, are lovely.

As he drops, perhaps with a careless "pink, pink," from the beech branch, whose fattened buds of oldgold and flesh tints are beginning to unroll their green, into the grass at the roadside, we are surprised by a beauty that surprised us last spring and a dozen springs before.

The chaffinch is as polished and smooth as a diving duck floating at the harbour bar. I know of nothing that is turned out by Nature more spick and span than the cock chaffinch of May. The birth of a new feather in spring may somewhat remind one of the birth of a new leaf. Both have long been in the bud, though the begetting and growth of the bird dress are more cryptic than those of the tree dress. But this glow and colour on the chaffinch is not all born at the birth of the new feather. The fire is gradually laid, then finally kindled in the month of May. Fire is no violent image to use of the lustre of some birds in spring. The sheen on the breast and flanks of the pheasant, seen in the sun at this season, might be likened to a little flame such as we get by setting light to some volatile spirit. 
This colour and this burnish, then, on the feather of the chaffinch are heightened after the birth of the new feather-that is, after the moult. That they are inseparable from the nesting season is not to be doubted, but it is remarkable that they are at their height sometimes not at the time of the mating or pairing season, but weeks, even months, after it. Most of the chaffinches pair in February or March : if the one aim and end of colour and burnish beauty in the male is to win the female, why is not this beauty at its best then? Why does Nature keep for May what was meant for March? Here in the breast of the chaffinch in May is one out of many similar things in Nature to make us think that there is beauty in the world, beauty in various provinces of life, over and above that large amount of it that has been expressly fashioned for utility.

As the all-for-utility theory breaks down, I think, in the case of so much beauty of colour and pattern and glow in wild life-bird, flower, and insect-so it breaks down in these singing performances. Utility is a master key to very much-a key always bright from constant use, made of iron that never rusts. Yet there are locks it cannot turn. There are chambers with doors closed and sealed against it. It cannot show us everything about a bird's song or a butterfly's colours; it cannot tell us why the world began.

A thrush set me thinking that the mere utility theory about all bird songs must be a mistake. Plea- 
sure in the singing, triumph in brilliant execution, this, whatever the origin of the habit, is often the motive for song in birds to-day. I quite see that as the male bird delights in singing well, so his mate or mate-to-be may delight in listening to songs. But I doubt whether the song really has such a great effect in securing a mate as some have believed. If it had, surely we should more often notice the hen birds paying marked attention to their singing suitors, critically listening to the performers. But in Nature the obvious listener is not the courted hen bird, rather some rival and interrupting singer.

From the thrush I turn to the summer warblers, and I begin naturally with the nightingale. Once I thought the nightingale was distinctly more a day than night singer-that often he sang only by spurts after dark. I still think, could we measure the volume of his day song, we might find it exceed his night song; and the same may be true of another musician of the dark, the amazing little sedge-warbler. Both birds must give part of the night to sleep, a part as long at least as that which is given, during daylight, to the pursuit of food. Both seem to sleep and wake fitfully after dark, and I have never understood why the wood should be loud with nightingales one hour or one night, and the next be still. Like the sedge-warblers, the nightingales will sing on the inkiest May nights and on the brightest : the state of the light seems little to affect their singing. Nor am I sure . 


\section{LIFE AND SPORT IN HAMPSHIRE}

that coldness at night lessens much the flow of the nightingale's song, even if it affects the quality. Probably what most affects the quality is practice; hence the nightingale does not reach his zenith till he has been several weeks in full song. If tradition in this, as in other things about the bird, is faulty, and the nightingale is after all chiefly a day singer, none the less the time to hear him is after dark. On stonestill, pitch-dark nights, such as we have in Maynights with what a spell!-the world is a soundingboard for the nightingales.

It is very good to go quietly out of doors late on a May night, when the last light is out and the village sleeps, and to wait in the grave stillness for that first "low piping sound more sweet than all." It begins slow, intense, and wailing; then quickens and enlivens, and leads up to breathless passages, rattling, clamorous, marvellous for power and execution. It is the musketry of music, full of flash and brilliance.

"Brilliant" one feels to be the exact word for the nightingale; and brilliance is peculiar to the nightingale among English singing birds; it should not be said of thrush or blackbird. Nor should one call the sedge bird brilliant in song, though his staying power is so astonishing at night by the river, and some at least of his notes so good.

To stand on the soppy grass one tranced night near moist mid-May, listening in the stillness and dark for the nightingales, and then next night to look down 
from hotel heights at the straining, glaring life of a city-this is a curious experience. Two night worlds so near after all in mere mileage and yet in such utter opposition! It is not quite easy at the time we are experiencing one scene to comprehend how the other, too, is being enacted at the same moment, and is equally real.

The sedge-warbler sings best and longest after dark, when his haunt is close to a sounding stream that keeps him wakeful, for then attention is not diverted, as in daytime, by food or nest work. The sedgewarbler is a regular night singer; I do not know of any other English singing bird so wakeful through the night as the sedge-warbler, except the nightingale. But in June we have day songs from the sedgewarbler lasting several minutes without pause. There is a feature in the sedge-warbler's song that I have noticed in no other; he has many entirely different notes, and they often succeed one another so quickly, and are so mingled, that the effect is that of a duet, or even of three distinct performers.

The sedge-warbler is a little band or orchestra by himself. Several instruments seem sounding all at once: this is the illusion of his song, and it is so remarkable that one looks into the tree or bush to see if there is really a chaffinch or pied wagtail there as well as sedge-warbler! I have looked up, half expecting to see a blackbird flying off from the willow tree, for the loud cackle of protest has suddenly 
occurred in the midst of the sedge-warbler's song; but there was no blackbird to fly off-the cackle was the sedge-warbler's, which almost in the same moment was uttering one of his "pink" or chaffering notes.

Few people give this little bird his large due as singer; perhaps because he is associated with short, jabbering outbursts during the day rather than with the long, strange night songs.

We have many blackcaps and many garden warblers at home, but it was in a Kent garden one June day that $I$ found myself in a very Eden of blackcaps. Blackcaps are always fond of large gardens and shrubberies, but in this garden almost every flower bed, with its bushy centre of shrubs, held one or two; and their song was at its full, pure and fresh to a degree beyond which purity and freshness cannot go; wild and wayward too. The blackcap at his best is a rare musician. His passages are not so long as those hurried, babbling ones of the garden warbler, which near Deane in Hampshire I heard singing for sixteen or twenty seconds without the least pause, and he has not the instrumental power of the nightingale; he has none of the nightingale rush and rattle, trill and shake; and he does not leave with the listener the idea of burning passion. Nor has his voice carrying power to speak of. At one spot among the chalk hills and hollows I have often stood on a calm summer night, and heard snatches of song from a nightingale 


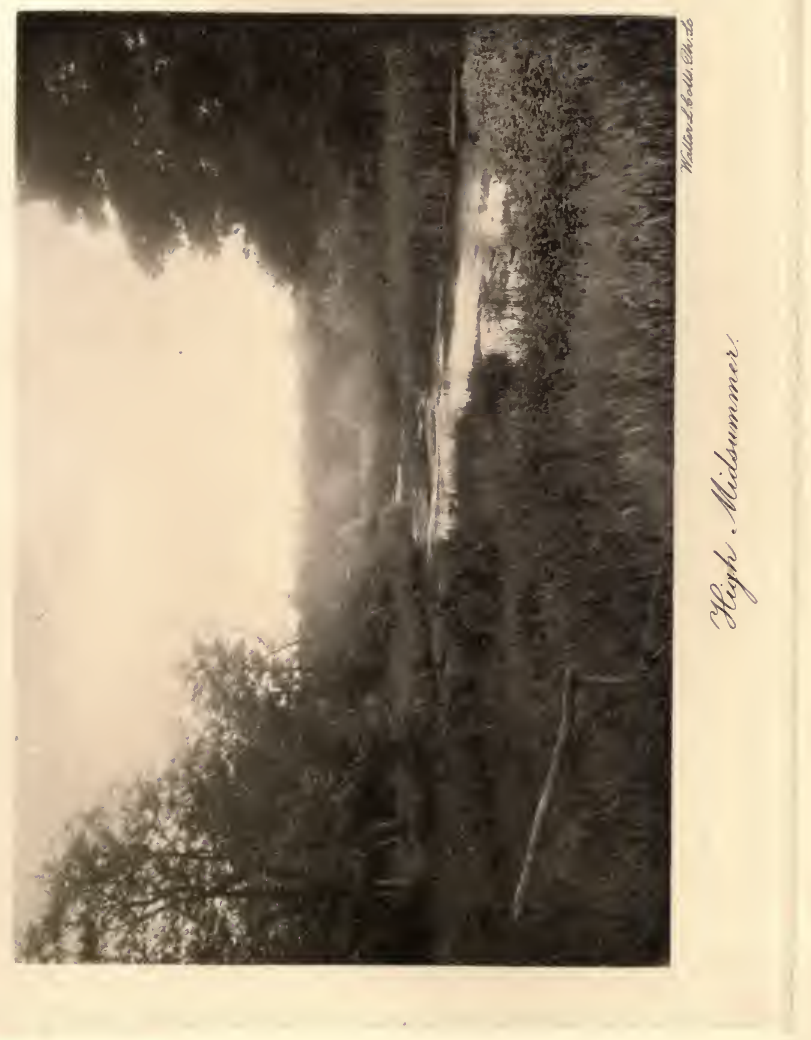




\section{$a$}


three-quarters of a mile away. There is a hill between me and the nightingale; yet it does not quite stop those wonderful sounds. The place must be favourable to the passage of sound; but, even so, think of so small a throat and tongue ruling the night like this, their sounds disturbing a mile of air! No wonder the old writer broke out into that praise"O Lord, if Thou providest bad men on earth such musick as this, what must Thou have provided for Thy saints in heaven!" The blackcap has not this mastery of space, this power of making silence loud. One must be quite close to a blackcap to get the best of its song. Hollow, shady groves in river valleyswhere the water flows quietly-are good places in which to hear the blackcap now and in July; for he sings on for a few weeks after the nightingale has ended. Here the blackcap gives a song that of its kind could hardly be bettered. The distinctive whistling notes of it are so choice. The timbre of the blackcap's voice is exquisite. The blackcap is rather a shy and casual singer, not laying himself out earnestly for song as thrushes or nightingales; so he is unfamiliar to most ears. His songs have often to be sought. They repay the search.

From the blackcap I turn to the little "leaf warblers." It is hard to overrate the meek willow wren. Strange how so many people who know something of birds, and care for their songs, are unconscious of this little sylph! It is the most con- 
stant chorister among our summer birds of passage. The April woods at home would often have been almost silent years ago had it not been for willow wren with cuckoo; blackbirds and thrushes were not so numerous as they are to-day; and after a cruel winter even large woods in some seasons would have only a few nesting pairs. But hundreds of the willow wrens would be in our great wood by the middle of April, and the constancy and abundance of the songs from the oaks and ash trees made up for the weakness of each song separately. Individual singers of the same species often differ much in merit; differ in the timbre as well as in the phrasing of the song. I had some correspondence on this with a writer who was always discriminating in his study of birds, Howard Saunders. We had listened to cirl buntings in different districts. His rendering of the bird's song was "zizi, zizi, zizi"- a triplice of "zizis" like the triplice of thrush "peeburs." I have heard the cirl bunting sing in this yellow-hammer way in late summer; but many cirl buntings I have listened to have a bubbling note, or bold shake, quite above the yellow-hammer level.

Birds may owe something, when their song is at its best, to the state of the air; I have an idea that they are better to hear in wet than in hot weather. After heavy showers the notes of some birds-as the cirl bunting - ring out clear and pure. Perhaps the air, rarified, clear of all floating particles of matter, 
is more sympathetic to their notes. Or, if not, it may be that the birds themselves are stronger then.

The frail little willow wren, however, does not vary so much as the cirl buntings and thrushesat least, the ear does not detect much difference between willow wrens. We cannot be too near the willow wren in song. To have this song at its best we should stand within three or four yards of the sylph, and not only hear but see the singer. The ruffling of the throat feathers and the way in which the sylph clearly puts all its little might into the thing make a dainty sight.

The willow wren's appearance when singing assures us-if we can come close enough-that there is nothing faint or half-hearted about the performer. Meek, gentle, and pathetic seem right terms to apply to the willow wren. Yet I believe it is, like the high burnished chaffinch of May, a bit of burning life.

By mid-August various birds begin to break the silence they have kept for a month. But there is one delightful exception to the bird silence at the end of July and the opening of August, the willow wren's. For about a month after mid-summer it is quiet as a nightingale. The one sound the willow wren makes in the woods and shrubberies is the poignant "wheet" when the nest or flown young are approached; it is a sound that bespeaks uneasiness, alarm; yet, uttering it, the bird is flitting from 


\section{LIFE AND SPORT IN HAMPSHIRE}

twig to twig, gathering grubs for itself or young; so I question whether the willow wren is quite so anxious as the "wheet" would assure me. This note is not peculiar to the willow wren; the chiff-chaff utters almost the same note-I do not know that I can tell the difference-and flits and hunts for food whilst uttering it; the wood wren's "wheet" is still more poignant, and in the same class I put the redstart's and the nightingale's. But the redstart and nightingale display more anxiety in their action than do the three little "leaf warblers." They closely attend to the intruder at their haunts.

The willow wren may be not quite such a sylph, such a fairy birdlet, as the wood wren; in his song he does not shiver wing and tail, nor make those entrancing, tremulous expeditions into the air which mark the wood wren; he is not leaf-tinted, not so fair in figure; but no bird gives me quite so well the idea of amiability, of pathetic innocence, as a willow wren. Wrens-ordinary wrens-are saucepots, tits are urchins, sparrows are street Arabs, lesser whitethroats are fidgets, exquisite little fidgets, but the willow wren stands for all that is gentle and unoffending to the eye and thought. He never gives us a "bit of his tongue" like some of these other lively customers; he has no assurance, no slyness. If only he were not obliged to seek and eat insects, one might say that he could not hurt a fly.

The willow wren will often sing in July and August 
when barely a lark note could be heard save at dawn, and when only the yellow-hammer sings in the heat of the day. Birch woods are more favoured by the singing willow wrens in August than oak woods. Some willow wrens in such places will sing all day. This song differs a little from the spring song, but I agree with a friend that it is fresher than when the bird left off in June. This is not an after-moult song, it is not a pairing, and I cannot think it is a courting song, a song of rivalry. It serves none of the utility purpose usually ascribed to bird music. Why the willow wren left off for a few weeks I cannot say; but I believe he sings now simply for the pleasure of the singing.

Late in September an exquisite little traveller paid a flying visit to my garden at breakfast time, and next morning at the same hour he was there again, for a few swift flits among the roses and the pear tree. He was the wood warbler, about the last of summer birds I should look for near the close of September. Nights when meadow and marsh are shrouded with the cold earth-cloud, and the stars glitter and shine with a brightness rarely seen through an English air, and the grass is white with frost crystals, seem unsuited to such a fairy form as the wood warbler's. Yet when the sun turned the crystals back again to dew, there he was among the blackbirds and thrushes, the liveliest little thing imaginableso slim, so volatile in every movement, that a pied 
wagtail, running and balancing on the grass a few yards off, seemed almost substantial, and leisurely in action.

The wood warbler is the third and last of the little group of English leaf warblers which I have seen and heard in my garden during the autumn migration. In different years I have watched the chiff-chaff and the willow warbler there, and have heard them both in September song. The wood warbler I never hoped to see in the garden at this season. A fourth bird, which does not belong to the group, but, through his size and movements, seems to come near it, is the lesser whitethroat; and I have seen him in the garden for a day or two at the close of summer almost every year. It would be impossible to improve upon the agility and grace combined in the lesser whitethroat as, restless, he slips through the twigs and branches. But I fancy that, on the wing in pursuit of insects, the three leaf warblers are slightly more frequent and deft performers than he or any other summer warbler is. And of this chiff-chaff, willow warbler, and wood warbler group, the last seems to me-if but by a fine shade-the deftest and the most constant in aerial venture.

I saw the wood warbler dart three or four times in quick succession out of a rose bush to snap up a few minute specks of insect life a yard above the lawn. This reminded me somewhat of the grey 
wagtail's spring and dart just over the grass when collecting food for mate or young in May-only the wood warbler is much the quicker in action. The wood warbler, once we really know him, can hardly be mistaken, though he is larger, or longer, than a willow warbler or a chiff-chaff, if only by a matter of lines not by the grosser fractions of an inch. I find it not always easy, save at very close quarters, to be sure whether a bird is willow warbler or chiffchaff; whereas there is something about the wood warbler-perhaps his greeny hues, his slimness, his light aerial feats, all three put together-to mark him out.

The window is shut; he is half across the garden, and, seen one second, is out of sight the next; it does not signify-that fairy figure and flight could only be a wood warbler's. His is a rare distinction. Wood warbler, redstart, blackcap, nightingale-are these not the stylists among our small summer birds ?

A pleasant task it would be to draw up a full list of the birds which in twelve months pass through or stay in a garden. The number of them, even in a garden of an acre or less and without a stream trickling through it, when added up may surprise us. The summer warblers are merely casual passers through the small garden, though often in passing through they will stop two, even three, daysthanks to green-fly. In spring I look for the black- 


\section{LIFE AND SPORT IN HAMPSHIRE}

cap, in the apple blossom very likely-a sight, once seen, not soon forgotten-or the pettychaps in the currant bushes. But $I$ think they are only travellers on their way to their summer nesting spots in copse and clematis lane. Another class of small-garden birds is made up of certain birds that stay all the year in England, but only visit the garden and shrubbery for an hour or so at a stretch from time to time during the season. The bullfinch, three of the titmice, and the missel thrush are in this class. The bullfinches come in pairs; and, though I understand, I cannot share the feeling of the fruit-grower against them ; for it happens that they have come to my garden on a few days in the year to search out, not the buds, but some trifling flower seed, and the sight of the plump, rosy breast and the bold black and white, at the edge of the grass, is very choice. Through much of the year the paired bullfinches are as inseparable as linnets-and it is as if linnets in spring and summer could not live out of each other's company for five minutes. A few days in the year a pair of bullfinches come for small seed, months between each visit; whereas the missel thrush will almost live in the garden, a week or fortnight at a stretch, when yew fruit reddens. Some seasons the goldfinches will nest in the yew; but, when they do not nest there, the visits remind $m e$ of the bullfinches; they come with that refined little "twit" for half-an-hour on a few late summer mornings to 
pick up grit from the gravel paths, and here again is the inseparable pair.

No account of wild birds' music would be complete that failed to note their undersongs. The undersong, faint and sweet, may be uncommon, but it occurs with several kinds of English birds. I heard the lesser whitethroat's whispered undersong in a Hampshire lane in 1905 , and two or three times I have heard the blackcap's. The lesser whitethroat sang in a deep, high hedge festooned with great masses of traveller's joy; it was the male of a pair that had their young round them. There could be no mistake, as the singer was quite close to me, and I watched and heard it for some time. This lesser whitethroat's song was pitched in a very faint key; a little warble composed of many indescribable notes, minute and packed. It was repeated several times, the singer, as it softly crooned to itself, searching busily for food in the lower part of the hedge. Years ago, at the edge of the woods at home, I heard a song pitched in a very low key by a blackcap, and could distinctly see the singer only four or five yards away. One evening in 1907, so late as seven o'clock, I heard a delicate warbling song given by a bird hidden in a maple bush. The notes were minute and crowded, and I thought at first the singer might be a lesser whitethroat, though the usual song of the lesser whitethroat has no likeness to this performance. I waited and watched, 


\section{LIFE AND SPORT IN HAMPSHIRE}

till a glimpse through the maple leaves showed a bird larger in build than the lesser whitethroat, and then a blackcap came into view.

He raised his crest-blackcap is hardly blackcap till that bonny crest is raised-but, reassured by my stillness, laid it flat again in a second, and continued his snatches of song; and then I wondered how, before I caught sight of him, I had not recognised the true blackcap quality of the song. As if to give just a taste of that quality at its best, he thereupon ceased his undersong for a few moments and broke into the wild, sweet whistle that we know so well; a blackbird had just struck up in a tree across the lane-this, perhaps, was the incentive.

The sudden change from the undersong to a snatch of the loud, full note was one of the most charming incidents that I have noticed in bird life for a long while, and the clear view I had of the singer added much - as, indeed, it nearly always does - to the pleasure. When the shy bird is screened from view, and we know that it is good to see as well as hear, there may be a sort of rivalry between eye and ear, and the pleasure is imperfect. How good some birds in song are to watch everybody must agree who knows the carriage and sprightliness of the singing blackcap, blackbird, nightingale, and wren. The first will raise and depress his crest, the second flirt his tail, the third-which also has a lively play of a 
red tail-pulsate with the exertion or ecstasy of song, and the fourth duck and thrill.

A charming sight in the Hampshire woods and thick lanes in July is the family of warblers, young and old birds keeping close company. I have a fancy that the lesser whitethroat family makes the prettiest of these groups. A feature of several of the warblers is a choiceness and grace impossible to convey in terms. "Delicacy" is a word one feels to fit exactly for a blackcap, a garden warbler, a lesser whitethroat. "Exquisite" is another word which one cannot do without when touching on the qualities of the refinest summer birds. These are words we ought to use sparingly. There is such a thing as a word-conscience; and to make stale by everyday use the fow choice, subtle, and curiously expressive words which language affords offends this conscience. But it is hard to be sparing of the use of them if we speak of many birds, flowers, insects. They will come to the tongue, are always in the thought when a blackcap or wood warbler is concerned.

The lesser whitethroats will take their young to a high coppice, and it is not hard to get close to the family whilst it is busy feeding on caterpillars among the maple or oak underwood. The old birds utter a low warning note to the young, which will suffer one to approach within two or three yards. Whilst the search for grubs goes on, and the young 


\section{LIFE AND SPORT IN HAMPSHIRE}

are being fed, and learning to feed themselves, an odd, small babble in low tones can be heard; it is made up of a great number of notes, creaky, gurgling, peevish-sounding, and bird-babyish. These mostly are demands made by the young for the attention of their parents, but mingled with them are the anxious and the warning notes of the parents. The whole thing is on such a midget scale of sound that we miss it altogether unless we $\operatorname{come}$ within very close quarters of this lovely little warbler family.

I have often described the lesser whitethroats, but I think it is only by repetition one can hope to give a notion of their neatness, their completeness. To the restlessness and spright of a titmouse they add the grace and choiceness of the warbler. I cannot see the larger whitethroat in quite the same light, though it has distinctive and pretty habits which the other wants-the habit of raising its crest excitedly when its haunts are invaded, and the habit of tossing itself into the air over the hedge and chattering its song on the wing.

I have seen, too, the garden warblers attending their flown young. They seem to me fussier than the lesser whitethroats, and keep up an incessant "chat" or "chack" at the intruder. One thing is often to be noticed about these family gatherings of birds in July - the number of the young is small in each party. Sometimes the old birds are waiting on a single chick, 
sometimes on two, three, or four, but the number of chicks rarely answers for long to the number of eggs which the warbler's nest held. A vast number of young birds come to a violent end between hatching and fledging time. The bill of bird mortality is very high. Nature scatters her young birds abroad with the squandering hand. She is a life spendthrift. The single bird is no more to her than the single seed. The individual failure or success is of no moment.

I end these thoughts on warblers of spring and summer with the rook, for the rook is a singing bird: listening to him in spring I could not doubt it. It is his, not the missel thrush's, distinction to be giant singing bird in Europe, as the golden-crowned wren is midget. Anybody who has been under a rookery at dusk, and listened to the turmoil and jabber of the birds preparing for sleep, knows their vocabulary is quite considerable. A plain "caw" and no more is commonly ascribed to the rook; but he has a dozen, a score of notes besides, which can be heard at any season. The most that people have allowed is that the rook's voice in spring slightly alters, becomes less harsh-a droll attempt at a love note. But in truth the rook has a song in March and April. An isolated rook came to the top of the great beech tree in my garden, and sang for ten minutes. I do not believe this was unusual; rooks throughout England must be singing whilst their mates are laying eggs or sitting. My rook began by calling loudly to any other rooks 


\section{LIFE AND SPORT IN HAMPSHIRE}

that might be near, in the common "caw, caw" or "quarr, quarr"; this he repeated at intervals, glancing round inquiringly the while as if for companions. Between the calls, he gently warbled. More than a century ago one of White's brothers kept a diary of domestic events and weather and wild life at his village, Fifield; the diary has not been published, and is now out of the country, but I recall a few passages in it, one describing the ravens in the great wood at Abbots Ann as "a-warbling" in spring. This word would well suit the rook in the beech tree. His was a song full of the low, complacent sounds which one associates with the word warble.

It was as if he sang just to please himself. It reminded one, in its lowness, though in nought else, of the choice undersong of some acknowledged warbler, blackcap, or lesser whitethroat. The rook sang scarcely louder than they. You would not call his notes melodious; some were quite like the little clucks of a farmyard hen when she is scratching the ground for food; others sounded as if he were clearing his throat, and were rather hoarse. He quorked; he quarred in undertones; gurgled softly; and all the while his body was gently moving, somewhat as a starling's does in song. But his tail moved more; now and then it would be pushed upwards, as high as it would go without disturbing his equilibrium, and slightly opened out, fan-like.

The carrion crow, like the rook, cuts a strange 
figure as lover. If his song is not quite so monstrous as the screeching, snoring barn owls, it is, to our ears, ludicrously unsuited to courtship and gallantries. The crow's voice is like the voice of something that has never known youth-dismal, harsh, croaking. There are times when the voice is not without a certain fascination. It well suits the great blackening woods on a winter evening, when crow is calling to crow; then it has a warning note, grave and aloof, that goes well with the scene. But the carrion crow in the bright sunshine of a March morning indulging in a musical solo-a carrion crow in the melting mood is wholly grotesque. The thing is not unusual. I have watched these crow idylls in London in March. ${ }^{1}$ The bird will perch on a tree all by itself, and for ten minutes or more call to a mate that does not necessarily appear. Apparently it little affects the performer whether the hen bird comes on the scene or not. He carrs his harshest, several "carrs" in quick succession- " carr, carr, carr, carr" ; only in each note the letter " $r$ " is dwelt on more than here represented-it is vibrated. Then a pause of half a minute, then four more "carrs." Each "carr" is accompanied by body action; he thrusts forward his body; he draws out his neck to its utmost length; he solemnly bows. This bowing in season of courtship and passion is not peculiar to crows. It is very common among

1 The carrion crow is a London bird, but I have only once seen a hooded crow there. 


\section{LIFE AND SPORT IN HAMPSHIRE}

pigeons. In spring we can hardly watch for five minutes a few pigeons on a roof without seeing the strut and bow. Wild pigeons bow, too. The tame pigeon keeps his bows till the hen is at hand, and can be walked or run round and round. But the carrion crow bows-as the rook in March sings-whether the hen is present or not.

As for the voice of a crow during these monstrous idylls, I can detect no softening of it; the rook's voice distinctly softens, grows more melodious in early spring, but the crow's seems "past improvement"-a voice for some cave kitchen where a witch stirs in the cauldron her soup of newt and adder. 


\section{CHAPTER IV}

\section{BIRDS AND THEIR VOYAGES}

The song thrush, as we have seen, belongs to our whole woodland year. Save for those birdless weeks of late summer-which seem to end a natural year more than December ever ends it, to be a kind of dead point between seasons-the song thrush is connected in our thoughts hardly more with one month than another. The thrush is perennial in England. Many other birds we connect with certain seasons or phases of the English year. The redbreast by all tradition is a true autumn bird, but I recognise that in many places the starling and its babble are a more distinctive feature of delicate September mornings with their mild sunshine than the redbreast. The redbreast seems most in its element a little later when leaves are falling fast. I often think of starlings singing for the pleasure of song without other motive. Surely they do. Listen now to the starlings on the roof, or in the shrubbery, when you wake or are up and preparing for the day's profit and pleasure - you can scarcely doubt it. These homestead birds will often sing on through much of the day, certainly far into the September 


\section{LIFE AND SPORT IN HAMPSHIRE}

afternoon; but the time to hear them at their cheeriest is between seven and ten o'clock, when the sun is bright, after a night of heavy dew and a slight hoar frost. I am an optimist when at such an hour I hear the starlings. A good morning for starlings is promised when by ten o'clock on a September night the bow of the Milky Way is seen with the utmost distinctness bent across the zenith from horizon to horizon, and even Saturn shines almost bright, and the turf is already sopping wet with the dew. Next morning, an hour or so after sunrise, in the freshness of the mild day, the starlings strike up. I think they must sing before they eat in the morning - certainly before they attend seriously to food. If by its utterance and behaviour any bird can tell of pleasure and ease felt in good weather, and in nice surroundings, the starling does. In the starling choir in my beech and sycamore there seem to be no eager competitors who wish to raise their voices to drown the voices of their fellows. Here is room for as many starlings as wish to come, peace and ease for all in singing. Each sings unvexed by others around him. The more the cheerier. How good it is to wake in the morning and hear this charming, most friendly bird babble, and to see through the open window the grass flashing with the colours of Capella!

After these mild starling mornings come crisp, clean days, before the general turn of the leaf. 
They belong to a stage in the season slightly more advanced than the first charming days of delicate but undoubted autumn. I should not call them exactly delicate days, nor soft; there is relish about the morning air-a little shock in it. It is air charged with exhilaration; and when we go out. into it after breakfast, to find the mist lifting off the near range of hills, and the redbreasts all singing and sparring, the effect is electric. A curing property lives in such mornings. There is no mistaking the effect which this autumn air has on us; body and mind are set up by it. Life is so sensitive to weather. There are days all through the year which dull the surface of life: these days, sharp and bright, put a burnish on it.

The days I mean come during the seeding time of autumn, and this is when we see lively titmice at their liveliest. Years ago, a friend who knows well the marsh titmouse, told me it preferred the seeds of the giant sunflower to all others. I know now he was right: it is essentially the sunflower titmouse. The marsh titmouse is commoner than some people suppose. I find it almost everywhere I go. It is not well named, being at least as fond of woods and large hedgerows as of marshes and river banks. As the blue-tit knows exactly when to come for poppy seed, and the cole-tit for beech mast, so the marsh-tit appears on the scene just when the sunflower nuts are ready. Blue-tits and 
great-tits will come to share the feast with himthe great-tit rather aggressively-but neither strikes me as quite so much at ease on the disc of the sunflower as he.

At a little distance the disc, when it begins to lose its shape and to curl at the edges, looks like a piece of honeycomb; and the likeness grows when patches of white dots are seen amid the brown. These are the ripening nuts, or seeds, packed with perfect neatness, the shell of each smooth as ivory, and, in touch and look, rather reminding one of ivory. The package being so tight and firm, it is not quite easy to pick out with the fingers a seed, or, rather, the shell that holds the seed. The marsh-tit does not always force it out of the disc at the first attempt, whilst blue-tits are less expert than he is and are often defeated. Lying on the grass by a bed of giant sunflowers beginning to ripen their seed-a perfect way to spend an hour of autumn sunshine-I have found the place a flitter of titmice. The marsh-tits, so spick and span, with their comely black bonnets, and the rest of them a good grey, are winning little things to watch. If plainly, they are boldly dressed; besides, have they not a series of notes that sound full of spirit and character? Perhaps, at the sunflower feast, we do not hear many of these notes, but we see the marsh-tit at delightfully close quarters. He will come with his quick, decisive flits straight to the disc of ripening nuts, and, clinging to the face of it, shake or force a nut from the 
package. Sometimes he will drop off the disc to a stem of one of the coarse, fading leaves, and draw out the kernel there, to flit up at the disc again a minute later for another nut. Two, even three, titmice-blue and black bonnets mixed-may cling at the same time to a disc; it is worth growing such a coarse thing as a giant sunflower to see this mixture. Every movement is natty, every note quick and sharp. I have watched a pair of chiff-chaffs in a tree by the sunflower bed hunting for food, and the contrast between titmouse and warbler has been very striking. The chiff-chaff can be fleet, fleet as a thought, when it will. See the pair chasing or toying with each other for a few seconds-they will whip round the tree, or in and out among the branches, fast as titmouse ever travelled. They can take an insect in the air, above their tree, deftly and sure as the wagtail takes insects just above the grass; or several insects at each flight, turning from side to side in short and swift jerks, like the wagtail. For all this, the restlessness of the chiff-chaff is almost restful compared with the marsh titmouse. The chiff-chaff has elegance: a titmouse was never elegant. The chiff-chaff, warblerlike, gives the idea of frailty: a titmouse looks a tough, tight birdlet, not to be buffeted much by wind or weather.

To realise what an essential feature of autumn is the redbreast one should go among the high moorland farms in a more northern county, such as Derbyshire. 
Here, on a still and misty autumn day, the redbreast's song is one of the three or four chief, simple things that make up the scene. It insists on notice, as do the stone walls, the groups of red-brown cattle, the mists, and here and there the lonely stone-built cottages and byres. Life in these places in autumn seems restricted to elemental simplicity, life both human and wild. There is no sign in such high, intensely quiet spots, when the whole earth and air is steeped in the feeling of autumn, of the crammed detail, of the incessant energy, that characterise life in many phases in the plains and valleys below, especially of summer life. A very few things seem to make up the sum total of Nature, and the impression is strong with us, as we pass the remote farmhouses and tiny hamlets, that human life itself can hardly be more complex here than in its environment. Stone walls-never plastered or concreted, but loosely piled up everywhere-little pastures everywhere, with their browsing kine; the redbreast singing by each far-scattered cot and byre: these, with the grey veil of autumn and the quietness which the redbreast's song deeply emphasises, are the sole things that meet eye and ear. I have driven miles among the moorland homesteads and pastures, along sharpbending by-roads, and noticed nothing else-not a flower, an insect, not even starling or rook; hardly a tree to an acre, and never the sign of a hedgerow. The redbreast plays a part in this act of the year, at 
least as marked as the part he plays in our southcountry woods and shrubberies when the leaf is falling thickly and the air smells of the must of autumn.

The darker the day, with the greater spirit, so it seems to one on the moors as in our home woods, he sings. This may be fancy. The mists and melancholy of autumn seem so unstimulating for song that the redbreast's lay comes to us as something of a surprise, season after season, and we may tend to exaggerate its vigour in such discouraging conditions for music. Yet if the redbreast be not really livelier, higher spirited, in the drizzle and darkening afternoons of October, he is not less a singer then than in clear, sunny weather.

There is always a tendency to find virtues in rarity that we miss in abundance in the common-known things of each day. This is so in our view of Nature as in our view of other things. The redstart, which flashes among the stone walls of these moorland byres in summer, is rare compared with the redbreast. So he has more beauty and interest for many bird admirers. But what living thing is such a noteworthy feature of a natural season as the redbreast? Shelley wrote of the "swallow-summer" and of the "owletnight"; the redbreast is more in the very tissue of the fall of the year, in its woof and weft, than the swallow is in that of summer or the owl in that of night. $\mathrm{He}$ is spread everywhere-high and low; is in wood, hedgerow, farmyard, orchard, in lonely places 


\section{LIFE AND SPORT IN HAMPSHIRE}

and frequented places alike. The best scenes of autumn in England cannot be thought of without a redbreast.

I feel sure the autumn song of the redbreast has nothing to do with the evolution motive of music. The evolution motive-put baldly-amounts to this : brave song, with gay colour, is the means by which the male birds attract the notice of the female birds, and are chosen as mates; the bravest singers and the gayest males are preferred by the female over her other less accomplished suitors; and hence there has been, from the vague beginning of birds, and still is in force, a habit which is ever choosing the most accomplished, spirited, and fine birds, and, doing so, is striking out the less accomplished. This is the survival of the most accomplished, the survival of the efficient. The most efficient being selected as mates, there is, through heredity, a constant tendency for the brave songs and the colours and spirit to pass down from generation to generation; and the race cannot degenerate whilst this law is in force.

I believe in evolution, and feel that preference of the most accomplished, working through heredity, is the main way in which birds, beasts, insects, plants have reached their present state. A great French observer, M. Fabre, does not, I believe, trust in this history of living creatures, though how he can doubt that, say, pearl skipper and larger skipper butterflies, or that ringdove and stockdove, come from a 
common stock, I cannot imagine. But, believing in this path of preference, I can yet believe in something of song, colour, and habit outside it. The autumn song of the redbreast must be outside it. The autumn redbreast is not singing during grey misty hours and bright hours, alike, that it may be preferred as a suitor or mate. The redbreast is not merely practising; Nature through her scheme of preference is not making its bird sing against next spring's nesting season. My strong feeling is that it is now singing for the earnest pleasure of song. Unprovable, of course, this is; only a strong impression. But such feelings, borne in on one with the weight of an instinct, after years of watching, listening, and after one has often turned the matter over in the mind, are not without worth. I dare say that rivalry is a passion that stirs the singing redbreast in autumn. But it is easy to think of rivalry in song as a thing quite apart from this preference of sexual choice in spring.

What dry drab things words can be, one realises in trying to describe a scene or two in a grand voyage of birds. Language lends itself with little sympathy to such drama as this, crowded with life and all so astir. One cannot get into words any complete idea of such a great bird stream as flowed for hours into the western corner of England at the end of 1906. It is only possible to record a few scattered facts and impressions: I feel this, though I happened to be right 


\section{LIFE AND SPORT IN HAMPSHIRE}

under the sky route and saw the last stage of the rush westward, and the return east next day. Certain glimpses of bird travel we can often get inland, in and about the wood, the redstarts singly or in pairs working their way south at the end of summer, swallows gathering in thick, twittering swarms in September, turtle-doves in parties of half-a-dozen coming quick and decisive from the sea in May; these are familiar inland scenes in the travels of birds. At the coast we see much more than this in spring and autumn. But unless we live under one of the chief highways of the air, as at Heligoland, or spend time in lighthouses at night during the migration, there is little chance to see twice in a life such a movement of birds as that of December 27 and 28, 1906. The migration was then at its height. The second day saw the beginning of the return journey, and the movement was on the wane before sunset; not that it was actually done by the end of the second day; the last loiterers who dropped out of the ranks on the way back may not have all regained their fixed winter quarters a week later.

On the first day, when I looked out of the window, I saw birds in flocks and small parties flying due west into the small strip of hilly country which makes the extreme western corner of England. The strip would be scarcely more than sixteen miles long by half as many broad, yet, on the day and night of December 27, it held millions of birds. I believe they roosted that 
night so thick that, if a gun had been discharged on chance in many places, birds not aimed at might have been killed in numbers; for I doubt whether the distribution over this bit of country was general and even, the travellers preferring to settle and spend the night in great concourses at certain sheltered spots. I first noticed this marvellous bird stream at about halfpast nine. It was flowing due west across St. Ives Bay and the strip of coast just south of the bay. Two hours later it was still flowing, though in lessening strength, and I think that, save for a few stragglers, it was over by about midday. But how long had it been flowing when I first noticed it? A man at Lelant told me he saw the birds coming across the water and land at dawn. The stream was a full mile broad, and, looking constantly across the water, I do not think $I$ once saw the sky clear of birds for a full half minute. There came parties, more or less compact, with hundreds of birds; other parties seemed to have thousands; and the gaps between the larger flocks were filled by little bands of half-a-dozen, a dozen, a score, by birds flying in couples, by birds flying singly. All travelled across the wind, which was blowing hard on the coast.

At times the air seemed full of birds. First I saw starlings. Their straight line style of flight and the neat, triangular appearance of their wings in action always make starlings conspicuous in a great caravan of birds. But I soon found that this was not parti- 


\section{LIFE AND SPORT IN HAMPSHIRE}

cularly a starling occasion. Fieldfare tail was as marked a feature as starling wing. Fieldfares were in every large flock. As for redwings, I had not thought all England held as many as crowded over St. Ives Bay in this wondrous stream of life.

That day and next, grassy spots near the sea were thick with redwings which suffered me to come near enough to admire their rose-tinted flanks. There were skylarks, too, and linnets and song thrushes, and doubtless other kinds of birds, though I did not see a blackbird. Thousands of birds dropped weary on the blown sand dunes just east of the estuary, where I found song thrushes and redwings so weak that they dodged among the grass tufts rather than take flight.

I saw four or five song thrushes clinging to a berberis against the south wall of a cottage and eating the fruit; and the effect of the bright berries and the fluttering, speckled breasts was charming.

Peewits, golden plovers, and ringed plovers were swept by the storm into the stream of migration, though I think they were no regular part of it. Whole fields were thickly sprinkled with the tired, hungry travellers. A party of circling curlew swung by accident into a rising cloud of redwings, thrushes, and starlings, and got mixed up with them, barely escaping collision.

The night of December 27 was wild and roaring, but the lull came before dawn, and for hours next 
day I saw the birds returning east along the sky highway they had travelled west. This return had the same appearance as the journey out. It was as if the travellers clearly saw their goal, with such fixity of purpose, straightness, and sureness of aim did they move through the sky. An express engine does not move over the rails with more fixity and decision than these bird hosts moved. It struck me they must be dead-sure of their route, that they could not miss the way or deviate a yard from it. Consummate ease and sureness were here, and a set purpose in every one of the travellers which only death could interfere with. This was the impression the whole migration made on me. How different this concentration, this absence of indecision, from the wavering of wood pigeons at roost time or lapwings in choosing a fallow to alight and feed in! True, many redwings, fieldfares, and starlings would, on their way back, drop out of their flocks or scattered parties to alight on fields and sand dunes. But presently they would rise to rejoin the continuous stream overhead, flowing always due west. Water that has found its level would as soon deviate from this level as the birds from their highway. I never before got such a notion of the majesty, the will of migration, of its rein and spur.

No summoner, no avant-courier, no leader (in the sense of authority), no follower (in the sense of submission to authority), no marshal, yet a marshalled 


\section{LIFE AND SPORT IN HAMPSHIRE}

host: these are thoughts suggested by this immense train of bird travellers. The train could not have been less than a hundred miles long. From one point on the cliff I saw it for two hours driving on through half a mile of space, and was told it had been passing over that half-mile nearly two hours before I noticed it. Thus, to put it at a hundred miles may well be to underrate that line of voyagers; for, despite the rough north wind, they moved west at a good pace, I should say from twenty to thirty miles an hour.

As to the strength of the wind, I noticed a curious effect it had on some of the fieldfares and redwings nearing the end of their journey; they appeared to flinch from the force of the wind above the cliff, wind perhaps at this point thrown up vertically, making a maelstrom in the air above; they drifted for a little distance sideways, heads turned from the wind, in some cases almost at right angles to it. But these may have been tired birds, which had dropped beaten among the sand dunes and after a while risen to their journey again. On the whole, the travellers flew clean and straight, their heads pointing due west, as if the hard side-wind little tried them.

The rush west before the snow and storm raises questions of deep interest. First, as to organisation. Here my belief is that there was nothing in the movement like human organisation. This is what 
I mean by saying no summoner, no avant-courier, no leader or follower had a place in the great train. True, this was not one of the set migrations which are features in the lives of birds of passage. It was due to a change of weather, a sudden pressure of snow and frost-scarcity of food set this train moving. But no doubt what applies to the irregular applies to the regular migration of birds: in neither case is there anything like human order and method. Migration is a sort of anarchy. No bird rules bird. Each goes as it pleases.

Nor do I believe that the route is first picked out by certain older birds, wise above their fellows. To assume this is to humanise birds. It is a tempting light in which to look at migration. It helps one over that problem, "How do the birds know their way?" But there are only a very few of the great questions of life the answers to which it is worth while to take for granted. And in any case it is idle to evade a hard question, such as migration, by enduing the bird with the method and mind of a man. Wild creatures have minds and methods, beautiful often, wondrously efficient, complex, refined; but, in these matters of flocks and societies and voyages, the machinery of their mind and method does not resemble the human machinery.

No division of labours, no allotment of duties, have given to the starling flock its marvellous mathematical precision in aerial exercises. No authority in 


\section{LIFE AND SPORT IN HAMPSHIRE}

individual birds of the flock in the mass, no discipline -as we use this word of human relations-bring together, start, and keep on the same sky-route the birds of passage. As there is no rule, no submission to rule, it must be anarchy. Yet in this state of unrule, this anarchy, there is something like symmetry and perfect accord.

Unanimity and simultaneity live in these great acts of birds.

I have not seen the lemmings of Norway in migration, but I imagine the same features are there; and in migrations of moths and butterflies. and locusts. Who would suggest locust leader or moth marshal ? Yet if there were such authority of the human sort among birds, why not among insects and mammals, which also set out on great journeys in hosts? Leadership, it seems to me, is out of the question. Every bird, locust, moth, lemming is his own leader. There are two barbarous terms in use to-day of human polity, individualism and collectivism. Well, Nature, for these great gatherings and adventures, suffers, and joins the two. The success of the union is obvious. Many birds, of course, must die on the journey or lose their way; but, compared with the host that drives on straight and sure to its goal, they are only the trifling few. It seems that, for the great journeys of birds and other wild creatures, safety and success depend on numbers. Travel, I suppose, is simplified through a host. Clearly the bird travellers feel they must keep 
together, for both by light and night they utter, as they move, an almost unceasing call. The fieldfare's coarse "chack" and the small, piercing note of redwing or thrush in the flock were constantly uttered during the voyage I watched, though it was broad day.

These things throw no light on the question, "How do the travellers know their way through the trackless air across land and water?" Indeed, denying that leadership or the experience of individual birds is a factor in migration, only makes the problem seem the deeper. It may be said: "They find their way by some sense-call it the sense of direction-distinct from and additional to those we are familiar with." But I would rather lean to the view that the secret sign-posts, the guides through space, which direct the birds, are due to the subtilisation of ordinary senses. Physical senses, which in us, through comparative disuse, have stood stock-still for ages, have in wild life been refined till they hardly resemble our crude ones. We cannot forget this in considering the skill and feats of animals. The manner in which wild creatures - mates or companions-keep in touch with one another, without being at the least pains to do so, is often a little wonder to the watcher. Here is good sign of that subtle refinement and that working together of the ordinary senses which exists in birds, mammals, insects. It is this refining of the senses and this working of them that avail so greatly in the long travels of wild creatures as in the short ones. I 


\section{LIFE AND SPORT IN HAMPSHIRE}

tend to believe less and less in a sixth sense or in a seventh. When we have really explored all the highways and by-paths of the five senses, and have learnt where they can lead to, it will be time to think about a sixth and seventh sense.

The impulse of migration being so strong, drawing the birds into its current as by a magnetic power, one can hardly doubt the wisdom and the need of it. To look at, it is more like the working of a law than a habit; the line of travellers as a whole might seem to move responsive to law as stone dropping to earth or stream running to sea. It would not be a great stretch of imagination to see the redwing and fieldfare rush in this light; it would not conflict with the knowledge that migration is anarchy, for it is anarchy only in the sense that there is no ruler and no authority in the flock. This is an idea that may have passed through the minds of other people who have watched a moving host of wild creatures. If migration began as habit, perhaps it has grown to lawsuch is the idea which a skein of migrating eels in the water or the line of birds in the air may give to the watcher. But, suppose we accept the law, it is still not clear in each case where the benefit lies. The passage of the redwings and fieldfares is a case in point. The journey out had hardly ended ere the journey back began. The storm abated the evening after the birds, jaded and famished, had dropped among the sand dunes, and the hills and 
woods across the water; and, next morning being bright and calm, the travellers returned eastward.

How was it worth their while to travel hundreds of miles to spend less than a full day in a spot which offered them no rich banquet? For, had it held abundance of food, surely they need not have hastened away next morning. Even about the hillsides, where they were forced to halt-the sea being in frontsnow lightly covered the ground on the morning they started back; and as they approached their winter homes that day farther east and north, they must have found deeper snow, and harder soil. One day they fled before snow and threatened famine; next day they returned to a country still white and frosted. It does seem as if this expedition had been in vain. The law of migration must be urgent, forced, and to good purpose; but it may show, exceptionally, a flaw; and I cannot help thinking that this bird host might have fared as well had it not journeyed into the extreme south-west.

Unfortunately, I have no exact itinerary of this movement. The birds came west, and next day disappeared east; returning, at the start, by the same sky-route-this is all I know of the itinerary. Where the movement began I cannot tell. But I am sure, through the vastness of the host, that it included birds which started far to the east in England, if not in the Midlands and even the north. Doubtless, as it moved on, it gathered recruits from many snow and 


\section{LIFE AND SPORT IN HAMPSHIRE}

frost bound places; the line-so orderly in aim and animus, though with no word of command to dress and drive it-growing longer and denser in each mile of progress.

So much for the journey out. The return, though marked from the start by the same straight aim and contidence, was more leisurely; for, as we saw, many of the travellers would drop at promising points among the sand dunes and feed there, to join the line again a little later in the day. I imagine that the return may have been as follows: The line, as it progressed east_and, later, perhaps north-gradually thinned, dropping a party here, a party there, many of the travellers settling down once more in the winter quarters they chose when they reached England in the autumn. Only in this way, it seems, can there be that nice distribution which is a feature of bird life between the migrations. The winter bird traveller, like the spring one, commonly, I believe, returns to its known and chosen place. So the redwings and fieldfares, that come hundreds of miles west, would go back hundreds of miles east; and those that only joined the line as it passed over, say, Dorset or Wiltshire, would, on the return journey, drop out as they saw their winter home lying beneath.

It is a flaw in migration that the travellers have little weather wisdom. Many wild creatures may be more sensitive than we to changes immediately impending. Electricity in the air may sometimes flash 
to them the news that a storm is being born. But it is a very little way into the future that the wild creature can feel or see-a few hours at most. The winter birds do not migrate till the frost and snow are on them, threatening famine; and flying one day before bad weather, they have no knowledge that next day the wind will drop or change and the snow begin to melt. There is no meteorology for wild life. It cannot weigh the air or read the skies. The feat of migration is marvellous. Its ease, concentration, unanimity are far above us. But has not its foresight been overpraised? Has it foresight to speak of? If man is very dim about to-morrow, surely the bird and beast are blind. 


\section{CHAPTER V}

\section{THE GUN}

IT is a happy saying that, among English field sports, angling is our friend. The meaning of this appeals at once to the angler who is also a gunner, a hunter or both. It was not spoken in a narrow spirit, or by an angler who could see no good in the other field sports; but, I take it, simply meant that with angling we can enjoy a quiet intimacy which does not live in the scenes of stir and many figures inseparable from a shooting or hunting party. To angle is to withdraw from society-to hunt or to shoot is to take part in it. Both have their advantages - there is a time for both. One can enjoy the quiet companionship that is in fly-fishing or float-fishing; yet at another time be exhilarated by the life and colour and gaiety that are in the shooting or hunting party. So that one can easily agree about the value of angling as "our friend" without making this an invidious comparison against the other sports. But I fancy that in some cases shooting can be almost our friend as angling is. It will not be so in shooting where a party gathers for the sport, and there is the crowd of beaters and camp-followers of the shooting 



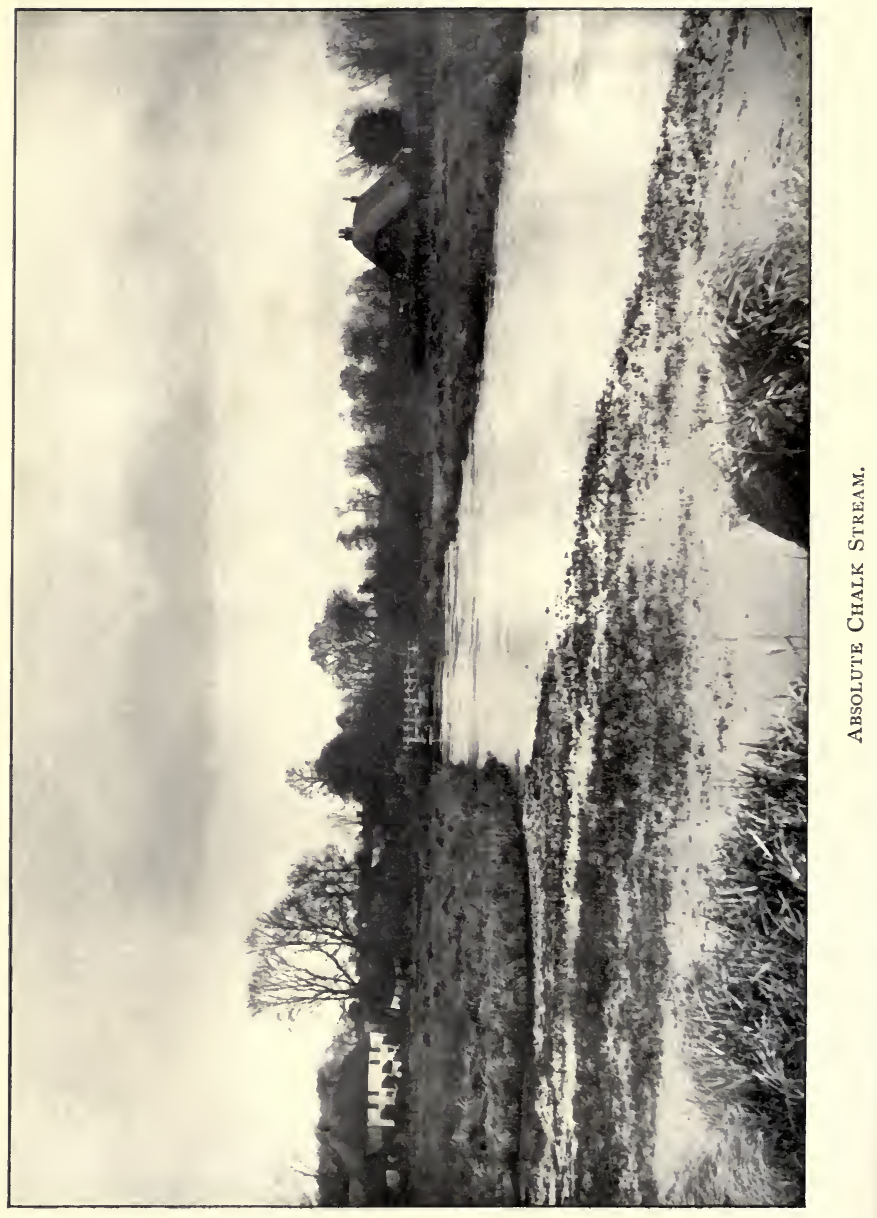


party and the arrival of the guns at the meeting place in field or wood, and the keenness to know of the plans and prospects for the day: these are features stimulating and delightful when we are in the mood for marksmanship and frankly wish for plenty of action. The hot corner, the big drive or beat of the day-one does often live intensely, if not always with equanimity, in such an environment. Shooting at these times is a fine excitement, a telling test of nerve and skill and temper. The talk about driven pheasants or partridges not really proving the sportsmanship of the shooter is mostly careless talk. When all has been said, it remains true that a man who can with clean skill and quickness stop his game is probably good enough anywhere as a shot. I should be the last to question the skill in this branch of shooting. But it is not the shooting that can be likened to angling as our friend. The shooting I have in thought is on the very small scale-taking up the gun on a winter day and with a dog or two going out into the large quiet woods by oneself, or with the keeper to beat and carry game and advise about the best strips of coppice or the best bushes on the common for rabbits and an odd bird or so. This is a style of shooting which I have constantly-with hardly a missed winter-enjoyed for many years past. It is this I mean in saying that shooting may sometimes be almost the intimate and quiet and sympathetic friend that angling always is. 


\section{LIFE AND SPORT IN HAMPSHIRE}

It is well to write from fresh experience in such a thing, and just before writing this I was shooting once more in the woods and on the high, breezy common of blackthorn and bracken for several days running in the old familiar way; the same keeper, the same kind of terrier and spaniel; the underwood coverts and the bunches of furze and blackthorn to all appearance just as they were when I first began to shoot among them in boyhood. Finally, the same kind of bag. Here are the results in game of three successive days' shooting; first day - seventeen rabbits, one hare, one pheasant; secondeleven rabbits, one woodcock, one pheasant; third -nine rabbits. On each of these days I was shooting by myself, with two beaters (one the keeper) and a spaniel and two terriers. The third day I was shooting for about two hours in the morning only: on the other days two hours in the morning, then a break for lunch and then about two hours again in the afternoon, turning home in the dusk of an ice-bound December. That walk home in the dusk of midwinter after the day's sport, what a feature it often is of rough shooting! Lights, the chink of tea-things -I think there is a kind of poetry of refreshment about tea-things after a day's sport, though the fine old copper urn has so long left the board-the blue flame and red glow and grey ash of wood logs; these at the end of the short day's sport are always part of the pleasure. But the walk itself-when a molten 
sun is sinking among the trees in a sky of those cold, chaste washes peculiar to freezing winter weather -is full of the wood charm. Nature has a way in these hours of laying such an impressive accent on her language. Each little sound is announced as a notable sound. We need not go to "faery lands forlorn" for faery sound and spectacle. The English wood has them in the winter dusk. A sigh in the spruce-the best evergreen a wood can have among its bare oaks - a clap of a pigeon's wing, a crow of a roosting pheasant, above all that fine hallo of tawny owl: here are words on the tongue of evening we often stop to listen to. If a man lived a thousand years, they could not grow so familiar as to be slighted.

As Nature at these times speaks with emphasis, setting a value on each word, so too she shows clear-cut, strong pictures; her touch is so incisive; to eye she appeals much as she appeals to ear. All day the bare underwoods may have been indeterminate in colour. They have not worn that blue which sometimes steeps them on mild winter days, nor the wine colour which the edge of some of our coppices shows in favouring lights where the birch stems prevail. North wind and an overcast sky, with a thought of snow or sleet in it, have blotted out any colour that can be described. But near sundown the clouds open a little in the west, and whole solid acres of young hazel coppice are painted 


\section{LIFE AND SPORT IN HAMPSHIRE}

warm brown. The only brown I know in English wood-scape that reminds me quite of this for soberness and warmth and evenness of tinge is the brown of great masses of dead brake-fern in full daylight. But the shades are different. I never quite realised the colour called hazel till one December afternoon I saw the hazel coppices in this most beautiful, quiet dress. The hazel-brown comes in the half-hour before dusk. Then through the dusk the monochrome grows, and when one reaches home at five o'clock or so in midwinter it is complete. Everything is clear-cut against the light quarter of the sky for a little time, and next the drape of night, and everything vague and mingled.

The best winter evenings are, I think, these hard and frosty ones, for they have the clearer skies. The wood pictures are drawn and etched on the sky with a firmer touch than on most evenings. The blacks are stronger. I am fond of the walk home across the common among the woods on a hard frosty evening, if only for the spiral flights of the linnet flock. This is one of the most beautiful sights in a year of small English birds. As the sun is dipping behind the pencilled, waved line of hills from the river Test into Wiltshire-Quarley Clumps and Danebury among them-the linnet flock will sweep and wind high above the rough blackthorns and scrub of the "rows" on this high common. Winding threads and ribbons of linnets for ten minutes or a 
quarter of an hour appear in the sky, till presently the flock drops among the bushes, and with an intense small chatter, like the hiss of the seething starling swarm at roost time, settles for the night.

Now and then on these evenings, returning across the common, or along the road between common and part of the wood, I have met with the woodcock, which perhaps I have sought all day in vain on the noble brows of Blagdon. Coming home one afternoon in November, when the light had just begun to thicken, I looked up and saw two woodcocks close together fly across the road within twenty yards of me. My gun was "at safety." The chance of getting woodcocks right and left was lost, and I left the gun at safety. I had not walked ten yards farther when the third woodcock flew over, well within range. Had my gun been ready, I believe I could have got three woodcock within a minute. The birds were making towards a blind track through the high underwood, where the keeper had noticed the mark of woodcock feet and the holes where they plunge their feeling bills into the soil. These lost chances in rough shooting, prizes that seem dangled before us by some Puck of the woodlands, add to the zest of sport: they are like the missed trout in fly-fishingthat great trout of a season that might so easily have been ours! A wild goose came slowly out of the Cornish estuary close by my boat. I was loading at the moment, the cartridge stuck, the gun would 


\section{LIFE AND SPORT IN HAMPSHIRE}

not close-and the wild goose was the one bird during that fowling week I wanted to get.

I have never seen the woodcock feeding, but one winter evening in black frost we stood in the west park for a few minutes by some spruce firs growing at the side of a chalk pit. Suddenly a bird wheeled down swiftly from the hazel coppice just behind us -its wings fully extended and clipt out clearly even in the dusk-and settled a few yards off among the mole-hills. Its back was turned to us, and in the few seconds it squatted there we wondered what it could be. It rose, and then I caught sight of a long bill. No doubt it had come down to try the open mossy park, and finding the soil iron-bound even among the lately-thrown mole-hills, sped to other foodground. We can see so little of even the habits of these feathered and furred people of the blind half of time that any glimpse of them awake and at home is something to value. The woodcock in the winter day gives me the idea of an owlish bird, dazed and random in its flight. But in the dusk it rouses to quick life. There was an alertness, a keenness, about this bird that wheeled down in front of us which $I$ cannot associate with the woodcock of day. I shall not forget the look of those full stretched-out wings, strong and noiseless, as the bird pitched. Even in that vague light it was a delightful spectacle of the feat of flight. This bird, not being scared, was noiseless both in pitching and rising. A woodcock that 
we flush in the day always, I think, makes one or two wing sounds at the start. I trod one out of the brake-fern on the common which rose within a yard of my gun. This bird swerved round a blackthorn before travelling four yards, for a beater stood in the line it first took; it rose clear of a strip of high underwood within the next few yards, and was over the road and lost to view in the "shoots" of Pound Copse ere I could run round the blackthorn. Random as the woodcock is in its day flights, only half alive, it yet has this power to dodge and swerve and mount the air suddenly, which is such a wonderful feature of strong flight. The body of a bird has through the gift of wings something that answers to our presence of mind. The woodcock's is a physical presence of mind.

The bags which I gave for example of a few hours' quiet work in the wood and common, may seem to some a mere playing with sport. But when I write them down I know they stand for days with no dull minute. This game has to be walked and sought for hard at times. For one rabbit bagged, two or three are shot at, either among the bunches or hassocks on the common, or the shoots and high coppices in the wood. Something, I admit, is wanting when the bag is rabbits only. A brace of pheasants -real wild pheasants, some of them having the old "black neck"-or a woodcock, or hare, puts the finishing touch; and then I admit nothing against 


\section{LIFE AND SPORT IN HAMPSHIRE}

the day's sport-unless it be faults of marksmanship; and these at times are galling. In the shoots or among the thick rows of scrub on the common, especially on the gently-sloping brows between common and wood where the undergrowth is thick dead bracken, rabbit after rabbit one day is missed. The day before, or next day, perhaps, every other rabbit shot at will be bagged, but I should say that this is above the average. Where there is but one gun, he will naturally try for game, furred and feathered, which, with two or more guns out, would fall more easily to a neighbour. Besides, these rabbits, hunted by terrier and spaniel, go very quick at times through the thick undergrowth and across the narrow rides and tracks. Even on the open common between the furze clumps and the blackthorn rows a rabbit is easy to miss when it is moving at its best pace. But in the open there are, say, forty yards of space in any yard of which to shoot him-that is, if he comes out of a furze clump within ten yards or so of me. It is different in coppice and thicket. Here often I have only a clear or partly clear space of a yard or so to shoot the rabbit whilst he is in the zone of fire. So that to get half-a-dozen rabbits without a miss among the blackthorns on the common or in the thick coppice wood-rabbits, I mean, that are full-stretched with the dogs after them-is a little feat in its way. To do this two or three times in the season is to do well with the gun. 
One rabbit to three or four shots is perhaps about my average on the common.

You cannot have harder rabbit shooting than this. Driven rabbits are not harder; often indeed they will cross the open spaces in a half-hearted way. It is another thing with pheasants. The pheasant put up by the dogs or the gun is not so hard as the high bird moving at full strength over the gunner in position. Yet these wild birds of the wood are not the tame sport and easy victims that some people think. Say they rise forty yards or more from you among the trees and underwoods. It often needs a quick, sure management of a gun to bag your bird. But I would not strain this point. Let us say frankly that those pheasants put up by gun or dog, and shot then and there, are as a rule easy compared with the driven bird-when the driven bird is skilfully "shown" by the keeper. True, one has found more pleasure in the shooting of a brace of birds walked up in the wood or common than in many brace of driven birds; but this is partly because they are so few and need such a search, and partly because of the charm of these familiar scenes.

The woodcock has always been the prize of the day. I doubt whether one's keenness to get a woodcock or two in the day's rabbiting loses any of its edge as time goes on. The whole scene of my first woodcock in boyhood is fresh in the mind to-day. 


\section{LIFE AND SPORT IN HAMPSHIRE}

It was sprung by the dogs from the dead bracken on the common. I see the dogs working, have in mind the angle at which I took the bird, and how I put it in my pocket and held it there, half afraid that it might disappear ere I reached home. But I can recall woodcock scenes of late years almost as clearly. Nor is a woodcock badly missed soon forgot.

The woodcock never stays over the winter and early spring to nest with us, though many years ago a pair bred in a large wood on the other side of the valley, a wood that was largely grubbed and turned into farm land in the 'seventies. ${ }^{1}$ Large and very lonely, our wood seems well suited to the nesting woodcocks, but other likely woods I know are also without woodcocks in the breeding season, though they have a fair number in autumn. There is a wood near Bletchley which I have often visited, where the bird is common in winter. With its undergrowth of grass and fern and bramble, it looks the very spot for woodcocks in the nesting time. In the dell a stream trickles all the year through the edge of the wood. Here they might bring their fresh-hatched young. But though a dozen woodcock may be in this wood in November, they will be gone ere May. In a long period of years only one woodcock's nest has been found. The man who came upon it was searching for pheasants' eggs. 1 "Wild Life in Hampshire Highlands," p. 272. 
The young woodcock were just out, the neatest little things. We know with what sober but perfect finish the bars and trifling figures, brown and black, are wormed and worked together on the full-grown woodcock; in the toy bird fresh from its shell this process is beginning. The egg-searcher at Woburn had scarcely seen anything prettier than these chicks. He told me they looked like "striped velvet." By velvet he meant to express an idea of their softness. For simile and image you would not go to an eggsearcher or game-watcher. Yet this man's few and slow words, with homeliest phrasing eked out by hand show, bring before one the nesting-place amid the dead oak leaves and the tufts of grass, and the chicks. His words make pictures. What is the secret of this eloquence in many a field or down worker, who has no book-learning nor taste in words? Probably it lies in sincerity; in this and the sense of intimacy with wild life which such men convey to us in their homespun speech. The egg-seeker unconsciously paints

"The thing as he sees it,

For the God of things as they are."

No sooner does art come in, and the jugglery of words and phrases, than sincerity is in danger. Something of it may go even in the conscientious pursuit of "the right word." The least suspicion of artistry in these intimates of Nature and the charm would be lost. 


\section{LIFE AND SPORT IN HAMPSHIRE}

Few things about wild creatures are more puzzling -unless we credit them with special senses-than the way in which they can keep in touch with each other. The woodcocks in midwinter are a good instance. I am sure that, in large and thick coverts, woodcocks at a regular hour each evening, will often fly together to their feeding grounds. Woodcocks will sometimes rouse themselves, when the air begins to thicken and their day doze is over, and fly singly to the scene of their supper, or rather their breakfast. But it is not unusual to see them at this hour flying straight and quick in couples.

Whether such companions are actually paired or mated I cannot say, though it is not hard to believe that some woodcocks, like other birds, do live in pairs through autumn and winter, even in a country where they will not breed in the coming spring. I have long thought it possible that mateship can exist between birds not only out of the nesting season, even between the autumn and the spring journeys, if not during migration. The way in which birds often feed, play, fly, and roost in couples during late summer, autumn, and winter points to this. I am not sure that mateship or the pair state must always be lost even in the flock. At any rate, when the flock breaks up at the close of winter a large part of it may well dissolve into pairs. I hardly suppose that when the pigeons and the peewits break up, in March or February, the members of the flock 
will all drop away singly to spring quarters; in the act of scattering they may often pair off. Is it not likely that there are some paired rooks in the winter flock? Seeing how easily unflocked birds can get in touch with each other, or, having lost, can regain touch, it is not hard to imagine that mateship may exist in the crowd.

How do the woodcocks, say a few birds, at most a dozen, scattered by day through a large thick covert such as ours, find companions just before dark and fly together to the feeding ground? True, they sometimes lie close to each other in the dead fern and undergrowth of the wood. Then it is easy to understand how, rousing at the same minute in the thickening light, they will fly off in company. But isolated and scattered birds, far apart in high wood or coppice, are differently placed; and yet I think they can, by some refinements of sense, remote and obscure to us, easily get in touch. The solitary woodcock, which you flush, and which flies wildly in and out among the oaks till it alights haphazard among the fern and dead leaves, there to squat till nightfall, is not long lost to its companion. Nor has it lost its bearings; or, if it has lost them after that startled flight to a part of the wood perhaps never visited before, it will recover them when it awakes fully and rises on the wing a few hours later at food time.

As the bee has a flower chart in her brain, so 


\section{LIFE AND SPORT IN HAMPSHIRE}

the woodcock must have the plan of the covert. A woodcock cannot be lost in a wood, however big and thick. It has some unerring system of sign-posts that point the way to its mate and to its feeding ground.

Through this wonder-in-little, the wonder-in-greatthe immense journey across sea and land, often made in the dark-becomes a little more intelligible to us. We sometimes think and speak of migration as if the birds were equipped for this journey with some unknown sense of direction and with some gift of special flight. But, seeing how quickly the woodcock becomes familiar with its autumn haunt, threading its way through thicket and dingle to feeding grounds, and silently and surely finding mate or companion, we may doubt whether there is need even in migration for special sense equipment. It would seem as if the fullgrown woodeock's science of direction and knowledge of its whereabouts were always as perfect as need be. Of course there are many wild creatures, furred, feathered, and scaled, which find each other and keep in touch by obvious methods. There is nothing subtle about the way in which the foxes find one another in the wood at night; or the crows or owls. Here the guide is one of penetrating scent or sound. Eagles and falcons and high soaring birds of prey need never be out of touch for long; sight is a true and easy guide for them.

Where the clue is neither through the ear nor eye, 
we know it is often through scent. Scent that clings for hours and carries for miles is the resource of so many of the unwinged and mute wild creatures of wood and open ground. Nor is it confined to the wingless. The sly collector has learnt how to lure his emperor moths simply by imprisoning the fascinating lady moth in a cardboard box and setting this down on the heath. Here I think the clue may be through refinements of refinement in scent. If not, the emperor moths can only gather round the charming box through a sense the nature of which is unknown to us-some mystic telepathy in moths.

Touch, taste, sound, sight, scent-to these we are sometimes tempted to add a sixth for wild life, a sense of direction; but direction would scarcely explain the gathering of the moth suitors. We must either imagine even a seventh sense or fall back on the sense of scent. My feeling is that all these problems as to the way in which wild creatures, without guide, compass, or obvious clue, find each other and their path through pathless space, may one day be traced to the subtilising of the five known senses.

Whilst shooting in the woods or on the common to-day I rarely see the carrion crows as I did in boyhood. For years one lonely carrion crow in the great oak wood defied every effort of the gamekeeper to trap or shoot it. This bird was last of 


\section{LIFE AND SPORT IN HAMPSHIRE}

the gang of black robbers that once haunted the place. I have counted dozens gathering and calling each other on a winter afternoon, just before the roost hour. In those days I could get as many crows' eggs as I chose, for the birds would line their nests in April, before the leaf was green. These nests, bulky, and set high, were soon found. I have climbed to three or four in a day. All I needed was a short ladder, by which to reach the lowest branch of the crow's oak. After this, it was a safe adventure from branch to branch to the fork where the great mass of sticks and wool was tightly packed and fixed. The inside of the nest was thick and warm, and nicely rounded. The carrion crow is no sloven builder, and in this favourite haunt I never knew the bird patch up an old nest.

Now and then the gang might lose one of its members through shot or snare; but not till a young and keen man came on the scene was war really waged against them. This man, truly an intimate of the dawn, would be up and out on his rounds by five in the morning. I met him lately in one of the rides at eleven on a wet autumn morning; he had then been out for a good six hours, and was beginning to think with a relish of his midday meal. He policed the wood. $\mathrm{He}$ did not trouble to rifle the crows' nests or lie ambushed with his gun. His cure for crows was quick and terrible-something from a phial. Then 
the robbers ended all at once. Of that sable band perhaps this bird alone escaped. Season after season it could be heard calling for a mate.

The carrion crow is a hardy villain. That hammer head and coarse, wicked bill tell their own tale. Robbery, often with violence, must be his frequent trade. $\mathrm{He}$ is black as he is painted. $\mathrm{He}$ strikes down the wounded thing-a mercy; but he hunts and strikes down the young and weakling too. How can a gamekeeper's hand not be against the crow? Yet the escape of this one out of the doomed band rather appealed to me. I often asked about him, and felt a secret small pleasure in the news that he still lurked in the wood deeps, refusing any bait. And, after all, the harm a single crow can do in a great wood is limited. Last autumn, however, the place had three or four crows once more, and the keeper thought there must have been a nest in the spring. Perhaps the solitary found a mate by March and nested in the hidden heights of the spruce firs. It is about these noble evergreens that one of the buzzards has been sometimes seen, or a passing peregrine that may take toll of the wood pigeons.

The keeper tells me of the wariness of the carrion crow with wonder and amusement. There is little indeed about wild creatures to interest the woodwise worker more than their craft; the restless suspicion the stoat has of steel teeth slily sprinkled 


\section{LIFE AND SPORT IN HAMPSHIRE}

over with fine mould and dead leaves - the way a rabbit will listen to and dodge its pursuers-the running and crouching of French partridges in the copse. As to "Frenchmen," the keeper says they will run like an old cock pheasant, and I think he may be right. I have heard scattered birds calling in the young hazel wood, or marked them down in a certain place, but on going up have failed to flush them. I think the French partridge and the old cock pheasant must prefer flight on foot to flight on wing because in the cover they feel that they will thus expose themselves less to sight and danger. The English partridge may not run so much as the French bird, but it is curious to notice his discrimination between dangerous and harmless figures. Look at the covey in the young corn, or the fallow, close to the highway; you drive by them at a walk after the day's shooting, point them out over the low hedge to your companion; they are not discomfited. Several are watchful, two or three crouch low, it is not worth while to be up and away; and no sooner have you passed than they are feeding again. Yet these birds may have been flushed and shot at repeatedly during the day now closing. They rose wild as hawks when the beaters began to range over the fields, they flinched at the sight of a gunner ere a shot had been fired. Again, partridges will distinguish between dangerous and safe figures on foot in the fields. The farm worker can often get 
much nearer to the wild covey or the pack-though he makes no effort to approach them softly or to hide himself-than can the solitary gunner.

This wariness of the wild creature, at once how great and how little it is! Eye or ear or nose-it is by these that the hunted bird or beast can shun danger. These defences have been wrought to perfection. Ear of a rabbit, nose of a deer, in their instant and exquisite sensitiveness might be likened to the wonderful instruments of the earthquake watcher. They register with its faithfulness and utmost delicacy.

Steal on the nibbling rabbit, and his ear may give him warning, though you are forty yards away, treading tip-toe on a mossy woodland walk, and his back is turned to you. As for the deer, though the air seem still he may get wind of his stalker a mile away. This is the strong part of the wild creature's defensive armour, the equipment of the physical senses-hearing, smelling, seeing. The weak parts, chinks in the armour, are those of the mind. They lack the power to reason out danger, to avoid the enemy by taking elementary thought. The rook, with its untold generations of experience, has learned nothing of the danger and distress in its habit of living in rookeries. Spring after spring its young are shot, it is thrown into fear and confusion. Yet it persists in its rookeries; and will be persisting a thousand years hence. The rook cannot convert crude ore of experience into gold coin of wisdom; and it is, I suppose, much the same with 


\section{LIFE AND SPORT IN HAMPSHIRE}

all forms of life on earth save one. Their sense provision against danger often seems developed to a point past which development need not go; but their mind provision hardly exists. At most, some of them have a memory, short or fairly long. But which one has the gift to think or reason out? If partridges had it, would they not fly back over the heads of the beaters, or tower high out of shot ere flying away over the gunner? Would not pheasants run far more than they do now? Would not rooks give up their rookery habit?

Fear chiefly lends the wild creature flight, not reason. Were it otherwise, the hunter's difficulties would be increased a thousandfold. The chase might become absurd. Give partridge or pheasant the thinking out, the planning power, of the meanest human brain, and the pursuit of the bird for pleasure or for profit is hard to imagine. Addition and subtraction tables of the mind the deer, rabbit, partridge are without; or, if they have such tables, the figures are very vague and incomplete. People forget or disbelieve this when they talk of the birds "setting sentinels" to watch on behalf of the feeding flock. I am not sure whether the bird scarer and the gardener do not fall into the same error when they hang up a dead rook or a dead jay to warn off their unwelcome visitors. A dead "crow" may be a scarecrow, but, if it be, it is not so through the birds' reasoning power. Who can quite imagine a flock of rooks coming to the 
new sown field, seeing a dead rook tied to the top of a stick, and arguing: "That rook has come to a bad end in this field: we had better go away, lest we, too, are killed by that enemy of ours who tills this field?" The dead rook on the stick may warn the rooks and wood pigeons in another way. It is something very visible, something unusual and alien to Nature. This may keep off the rooks and pigeons for a time, though an old boot or bit of fluttering rag would serve as well. So the scarecrow acts, but not in the way the bird scarer often supposes. Reason, save in a most primary form, is not shown by the rook that shuns the scarecrow.

Perhaps the keeper sets the mind of a wild rabbit too high. But others may set it too low. It is some years since I first noticed the wariness of rabbits on the breezy common, where their wits are constantly sharpened in winter by dogs and guns. Across the common stretches a belt of thorn and scrub, where the rabbits lie out in their "forms" among dead ferns and grass tussocks. Sometimes I have shot in this belt with dogs two or three times a week, as the game is plentiful and a woodcock often lies there. Many of the rabbits grow so wary after the belt has been shot a few times in the season that they will rise from their forms as soon as they hear the dogs giving tongue, and will slip off a hundred yards ahead of the guns. But, far more remarkable, they will avoid certain open spots at which a gun is usually stationed. I noticed 


\section{LIFE AND SPORT IN HAMPSHIRE}

this long ago, and I saw exactly the same thing one day a year or two since, and again at Christmas, 1907. The rabbits instead of crossing the open space within range of the gun will make a wide circuit across the open common. On the first shooting day of the season, on the other hand, they usually cross the open space within range. I have often been amused by the way rabbits, when the scent is poor, will behave in covert, with terriers and spaniels giving tongue loudly all around. They will hop gingerly about the thickets, often stopping to listen; they will quietly dodge and double, and having satisfied themselves as to where lies safety and where danger, steal away. A rabbit has crept up to within a few yards of me, and stood still to listen to the dogs yapping and tearing about on the other side of the thicket. Once in December a rabbit came so near I could easily have touched it with my gun, and when I offered to do this it hardly stirred a foot. Whilst it sat up just within the thicket among some dead fern and grass, its sensitive ears kept moving, for the rabbit trusts more to ear than eye.

These are not instances of special intelligence in individual rabbits. They are common to the wild rabbits of our wood; rabbits generally will steal about and listen when they are being hustled hotly by dogs that are confused by a bad scenting day; rabbits generally, I have no doubt, will avoid crossing certain open spots where they know by recent experience, by memory, there is danger. These are habits of 
wariness, shared by the whole species. It is intelligence that runs in grooves, like that of the honeybee. We do not find an individual rabbit striking out a special line of intelligence for itself.

A subject akin to this of the crow and the rabbit shunning danger is that of the partridge "shamming wounded" when her young are threatened. I came upon a troop of partridge chicks in the grass by the road across the downs-just the place where the old birds take their young a day or two after the hatching. Two families seemed to be mingled, for three old birds ran and clamoured in front of me. They spread out and brushed their wings along the road as they scuttled about, but here I could see no sign of "shamming wounded." One observation in Nature is ever contradicting another about the same thing; it is this which makes me shy of taking up finally this engaging theory or that. True, the little black grubs of the peacock butterfly on the nettle, when they are alarmed, always appear to sham death-though, strangely enough, not the full-grown grubs. But if one partridge or wild-duck, when her young are approached, seems "shamming wounded," another only seems trying by wing play to draw attention to herself. There is a great difference between a bird pretending to be wounded and a bird fluttering and dragging her wings to attract notice. To-day I have doubts about the "shamming wounded" by the partridge, though I do not deny 


\section{LIFE AND SPORT IN HAMPSHIRE}

it is possible; in the past I have been struck by it, and may be again.

Some of these partridge chicks were not strong enough to reach the hedge, and crouched in the turf by the road. And here arises another question - that of protection by colour and marking. These natty little brown-barred things bore no real likeness to their grassy surroundings. They had no kind colour and mark protection. All that can be claimed for their colour and pattern is that it is not cruel ; it does not contrast with environment, and so show them up to the enemy. But I must say that I have seen partridges just out of their shells, and they oddly resembled these shells; and also harmonised well enough in colour and marking with the rather bare bit of ground where they were hatched.

One must be very careful to see and record the many cases which tell against the theory of protection by colour and pattern, as well as the cases that tell for it. It may be said that we shall never reach conviction in this manner, that we shall always have chaos instead of cosmos. Then I would rather have chaos. I prefer the half truths of doubt to the whole lies of such conviction-the lies in the soul. In these things, is not the known and felt honesty of doubt a better thing, with all its failings, than the secret dishonesty of conviction which often must lurk at the back of the mind?

The duet of pheasant and blackbird is a feature 
of the quiet autumn rather than winter evenings. How often have I stood and listened to it as I walked home after a day's shooting! It is distinctive of autumn, though not peculiar to the season. The evenings that lend themselves to it are those with stir enough in the air to shake the little shower of leaves from the maple. An evening must be still indeed for this at the close of October, for even on a serene autumn day, when we are not conscious of breeze, the maple suddenly seems to have had a shake that brings straight and flat to the ground a shower of yellow and red. This quick little pitterpatter of maple leaves stops as suddenly as it began. The maple is motionless again. Not a leaf after this does it shed for an hour or more. There appears to have been no more impetus to set loose all these leaves suddenly than such a zephyr as makes the aspen shiver.

But on the evening when the pheasant and blackbird duet is heard at its best the air is not even rude enough for this-it does not loosen one maple leaf. The stillness begins to be appreciated about an hour before dark, and-a thing characteristic of wood silence-perceptibly it deepens, deepens. On the verge of dusk every item of sound falls distinctly on the ear. The silence then may be likened to the flat ground-colour of a picture or painted object, which shows up effectively every mark, however insignificant, that is made upon it. Thus from the 


\section{LIFE AND SPORT IN HAMPSHIRE}

clods of the ploughed field outside the wood the note of the corn bunting, ordinarily a trivial wheezy sound, is quite important, whilst the bubble of the cirl bunting in the hedge comes out strong. As it grows dusk it grows chilly, for there is no St. Martin's summer about the eves of late October. The pheasants are trumpeting to roost, a fresh outcry at each mount upward; every blackbird has set up chink-chink-chinking. The duet of pheasants and blackbirds rises high above all other sounds. Yet, if we stand still at the edge of the wood, we can hear other voices than theirs, small contributions to this evening hymn-its undertones. One of these is the "it-it-it" of the redbreast. The sound is as if you passed your finger, with slight irregular pauses, over the teeth of a comb; not a sound is this redbreast's with beauty apart from association. But association here is everything, so the redbreast is delightful.

A second modest contribution is the wren's ditty. Wrens are always brimming into song. They are at it till the very dark, even in the winter. They will almost sing in their sleep-I have certainly heard one wren sing when I disturbed it roosting, and it was only half awake. It seems as if it were purely automatic, this music of the wren. Anything, everything touches the spring which sets the music moving. During nest-building-for the cock wren builds nests with all his midget might-food- 
hunting, love-making, rivalry, battle, toilet, preparation for roost, this trim, jolly little creature is ever singing. His are the sprightliest lyrics. They are as the little songs in Shakespeare. Two wrens in neighbouring bushes in the autumn dusk will sing a dozen ditties against each other, and an odd feature is that often they will not interrupt each other; one ditty done, another begins after a pause of a second or so.

The blackbird's part in the duet between itself and pheasant seems to strike the note of excited protest against some unseen enemies, now and then turning to absolute terror. The protest is in the chink-chink-chinking note, sharp, metallic; the terror, when suddenly this is changed to cackling. The chinking is made when the blackbird is perched, though restless; the cackle, for which it is often exchanged, is, I think, uttered when the blackbird hustles out of the bush and takes to flight. The stimulus of quick motion seems to be required for the cackle. Chinking is common to song thrushesthough I think they do not often make a notable trio of this evening duet-and blackbirds; the cackle is the blackbird's own.

Just as of old-even more than of old-all my thoughts of shooting in these woods and the common are mingled with thoughts of landscape and wild life. I find there is no separating them. The scene, the home feeling, count so much. A curious union between contemplation and action this seems. It 


\section{LIFE AND SPORT IN HAMPSHIRE}

is perplexing how the two opposites can live with harmony in the same man at the same time. But certainly they do mingle in this kind of sport as in various forms of angling. I incline to think indeed that the harmony between them, or, say, the partnership, may be more unbroken than in the branch of angling on which I shall touch later.

The angling scene by the chalk stream in full summer is richer than the shooting scene in these winter woods. There are hours when it moves me more and sinks deeper into me. But the sport can be intenser in chalk stream angling than in this quiet way of shooting, so that I have sometimes had to recognise with a kind of shame that during the evening rise of heavy trout the wonderful beauty of the river scene, its sounds, scents, and colours, have formed but a dim background. All my full consciousness has been in the act of angling. 


\section{CHAPTER VI}

\section{A T THE ESTUA RY}

THE estuary has a powerful charm for the sportsman on January nights, when the tide is running out, and the moon barely shows through scud or formless cloud. The sands look as if lightly covered with fresh fallen snow. Coming thither with my gun after dark, I have half thought for the moment that snow has actually been falling, the ground all about being so wan. At dusk the curlews and dunlins will come out from the river to spend the night on these sands about the time the ducks are going inland from the sea to spend the night on mudflat and marsh. The hours and habits of waders and water-fowl may vary slightly in different parts of the coast, but I suspect that this move-in of the ducks and move-out of the curlews is general. Then at daybreak the ducks come out to sea and the curlews go in. This is the ordinary roosting and feeding rule of the birds: the ducks roost by day on the sea-well out in the open water if it is calm, near in by the harbour bar if rough-and they feed by night on the marshes and mudflats; whereas the curlews roost by night on the sands when the 
tide is out, and feed by day in the marshes and mudflats. Such is the routine. But wild weather makes many exceptions. Then the ducks will often go in much earlier; and the waders, finding the shore too rough, will return to the mudflats and spend the night there, resting or feeding. I shall never forget one evening in the West which sent the curlews, and with them the gulls and dunlins, back inland a few minutes after they had come out to roost on the sands.

The estuary suddenly grew black as the Styx, though it was scarcely time for the dusk; and back to the mudflats drifted the gulls, and, arrow-quick with the raging wind, the dunlins and sanderlings darted to the spot they had just left. The wind was too mad for any bird to sleep by the open sea that evening, though later at night, when the storm lessened, they may have come out again.

I saw two flocks of dunlin shoot back from the shore up the black river, and they moved like swifts migrating at highest speed. The dunlin flock by the shore and up the estuaries of southern England is a beautiful sight in winter. It flies with all the precision and air-ease of a flock of starlings; and that wild evening in the snow-blast the flock simply flashed by, riding full on the wind.

A few minutes later it grew to a savage storm, and there was a certain threatening personality about it. The snow did not appear to fall, but to drive 
through the air parallel with the earth and water, and it froze to an icy cake as it struck my coat. Ducks no doubt came in on that ravening storm, but I could not see them, could hardly hold the gun, and it took half-an-hour to struggle half a mile against the whizz of snow and sand. The sand was whipped up, and whirled in vicious showers that bit and stung. For the first time in my life I knew of the penetrating power of sand caught and scourged by a gale. My boots were full of it. Sand covered my wet gun, and was mixed in the sheet of snow-ice which fell or peeled off one side of my greatcoat in thin slabs when at last I struggled indoors. I yearned to take shelter by lying down behind a mound covered by marram grass, but was afraid to do so, for the storm seemed as if it might last for hours. The hardiest bird will not set its breast to such a storm as this on the seashore at night.

On ordinary evenings the curlews whistle to each other, and assemble, in little knots and roosting parties. I think they must sleep, yet throughout the night their beautiful note can be heard. I have tried to see the whistling curlews on a fairly quiet evening when the sky is overcast. I seem to come nearer and nearer the whistling, but there is something deceptive about it, for I cannot come near enough to see a curlew, though each step promises the discovery of a dark form on the snowy-looking sand. The curlew is silently up and off just before I am 
within sight of it. Now and then odd little sounds warn the walker that he will be over his ankles in another step or two if not careful. These sounds, sudden, rather startling, and only a few yards ahead, are caused by the smart collapse in the miniature banks of runlets that keep draining seaward as the tide runs out. They exactly remind me of the sudden splash of a large, scared trout that is disturbed whilst shrimping in a shallow ditch by the chalk stream. Sounds and scenes like these never become familiar. There is a touch of the eerie about them. I imagine they affect even the hardened, weatherworn folk who spend their lives about estuaries and great mudflats and grim river bars; the people of the tarred shanties, good judges of such a thing as a cockle, who boil the pot over a fire that spits and crackles with scraps of wreckage.

The wariness of wild life by the estuary and the shore, as in the wood, owes very little to reason. The wild creature soon learns to recognise its enemies, and is alert to escape them; here understanding of a simple kind is at work, but here it almost ends. The precautions taken against the fully recognised and dreaded enemy rarely involve the slightest effort of mind. Take the flocks of mallard and teal that float by the harbour bar from daylight till dusk, or, when the tide is far out, doze on the spits of dry sand. If they turned their experience to account they would be completely safeguarded against the 
gunner. In broad day the ducks at the edge of the sea, or afloat on the estuary, are safe as need be. Practically, they cannot be stalked. After dark they are safe on the tide and mudflats inland. But for an hour each morning and evening they are in peril. The twilight is deadly danger. The gunner lies in wait for them at certain spots between their day and night haunts. True, he often returns without a bird. The ducks, coming out to sea or going inland, passed out of range, to his right or to his left; or, tide and weather unkind to him, the ducks did not leave the sea till dark; or, in the morning, a minute after the disappointed flighter turned home, believing that it was now too light for sport, the flock passed over the very spot where he had crouched before dawn. This has happened to me. But the gunner only needs time and patience to succeed, if he has a good fowling-piece and the skill to shoot. One morning or evening the ducks will fly over him within range.

Again and again the flocks and parties, pairs and single birds, are shot at as they pass at dusk over the mile or so of shore and low-lying land between their day and night haunts. Every day somebody shoots, and often several guns are turned against them. There are ways by which the watchful flocks could easily elude the flighter. Instead of flying straight backwards and forwards between their day and night haunts they could make a wide, circling 


\section{LIFE AND SPORT IN HAMPSHIRE}

detour and so avoid the gunners lying in wait for them day after day; or they might rise to the height of a hundred or a hundred and fifty yards ere making each trip. The flighter, be he never so skilled and watchful, must then be baffled. But the wild-fowl, with all their wariness, their intensely nervous suspicion, are remote from such reasoning. We can hardly imagine a simpler logic than such an act of avoidance would imply-plainer syllogism there never could be for human reason. It would seem as if alarming experience must in the end force the mind of the wild creature to argue out and act on this conclusion. Yet the ducks will continue to go to and fro over the hidden flighter. Shot at and constantly harassed at a certain spot, some wild creatures will leave the district altogether. But this precaution is so crude and elementary, one can hardly think of it as a reasoning process. It seems a mere automatic shrinking from danger, no calculation about it; the slightest calculation would often enable the animal to remain safely in its haunt by some simple, effective device for escaping its foes.

What a desperately hard thing the pursuit of wild life would become if birds and beasts and insects began to argue out the simplest syllogism of danger: The chase might become almost impossible. Against the water-fowl we should want arms of far more precision and longer carrying 
power than we have to-day. A twelve-bore gun, the cartridges loaded with swan-shot, would be useless. Our dominion over wild life would be loosed, if not lost; for the logic of the bird and beast and insect would be backed by an intelligence of sight, smell, and hearing which far excels our own. Fancy if the wild duck's mind had been sharpened with its eye! If the bird were as mentally alert to danger as it is physically alert! How could we hope to match ourselves against it? The very thought of it to the flighter would be a nightmare of evasion. But the wisdom of the wild animal does not reach in this direction. It is wisdom mainly of one or more of the five senses, developed to a degree marvellous and exquisite. The wild duck is an example. So strong is it in this physical wisdom that we can never approach it when it is dozing by day at the sea edge. No matter how softly we creep near, its head will come from its feather bed, and in an instant it is up and away. Pochard, teal, mallard, widgeon-one seems as physically wise as another. Old shore-shooters say curlew are even wiser than duck. At wan dawn I have been within seventy or eighty yards of a roosting party of curlew in the open, but not nearer. The physical wisdom of both the duck and the curlew sometimes appear to fail them once they are a-wing. Curlew become much less wary and suspicious when they are flying in from the shore at dawn or out 


\section{LIFE AND SPORT IN HAMPSHIRE}

from the river at dusk. They will pass right over the head of a man walking or standing upright in an open place, and not swerve unless he wave his arms at them or shoot. Yet a minute or two earlier, in the same state of light, these curlews were allwariness. I think they may not be quite so well placed for seeing enemies and for guarding themselves when a-wing; moreover, they are occupied with the desire to fly to a certain spot, and this may lessen their attention to enemies.

There is a pleasure in watching, with the naked eye, wild life at the estuary and up the sea creeks. Glasses scarcely give such pleasure. The difference between identifying by eyesight and by glass sight is somewhat like the difference between hand-made and machine-made. The pains taken, and through them the triumph achieved, are so much more in the first than the second. In the one you do the whole thing yourself, in the other it is largely done for you.

When the machine comes in, the eye and the hand tend to lose or lessen their skill and independence. They can be trained no longer to their highest powers and finish.

Thus it must be better to distinguish a distant bird or beast, to pick out its colours and markings, and discover what it is doing by the unaided eye. And the eye in good training can do more than at first seems possible. This fact is clear to us after looking into a stream of quick running water, or into a quiet, 
deep pool of water. At first the eye can hardly distinguish anything in the water, and a dark or light form may or may not be a fish. By degrees the water yields to the eye its secrets, and what appeared a fish is seen to be a weed or stick. More often, perhaps, it is patience than power of sight that makes out the inventory of the brook. Even for sky work, with the unaided eye some men have been famous for the worlds they have included. Herschell sighted stars dark to most men searching on a clear night with the naked eye. He had sight, it was thought, of wonderful strength; but may he not have seen his extra worlds largely through patience and practice? The very strong eye often is a highly trained eye.

But to watch the wary water and sea fowl, and the smaller waders, glasses are needed. Half a mile away the flocks of mallard and teal floating by the bar of the estuary are scarcely more to the strongest eye than a sprinkling of black dots. The dots are a little distincter and blacker when the flock dabbles at the foamy edge of the sea; but even then the watcher cannot make out the forms of the birds or recognise the species through colour or mark. He brings a powerful glass to bear upon them, and instantly the flock floats a few yards from his feet. Then if the sun comes out, the green of the mallard shines, and the gloss, the beautiful smoothness, is seen at its fairest. The smoothness of the water-fowl, "diving duck," and others, is one of the most excellent things 


\section{LIFE AND SPORT IN HAMPSHIRE}

of bird creation. In seven wonders of wild life, I think I would give it a place; and a place, too, on the list of seven beauties. Think of the precision with which the millions - for millions there are - of branches and sub-branches of the bird's plumage must fit into place to achieve this surface of smoothness equal to polished ivory! About the neck and throat and part of the head of a scaup duck there is little appearance of feathers-just a surface of shining green and black. Yet the bird is constantly shaking itself with the violent action of a dog, and, doing so, it disturbs and puffs out its whole plumage. And, the shake over, each feather, each particle of each feather, slips back at once into the exact place where it should be. A little of this marvel is done by the preening of the bird's own bill-but a very little. If the mallard or the scaup duck depended on its bill for smoothness, it need be furnished with a bill incomparably finer and more sensitive than that which it has. An occasional detail of this toilet of smoothness is certainly done by the bird's own bill, here and there a plume awry set straight; perhaps-though I am very doubtful-oil may be drawn from the duck's oil-glands, and applied to the feathers where needed; but for the most part it is mechanical; the feathers adjust themselves.

Barbs, barbicelles, all the hair-fine lines and hooklets of that wonderful vane we call a feather, are set with a mathematical accuracy past our understanding. Here are order and regularity on a scale of precision 
and in minutest detail which it seems impossible even for Nature to excel. Death itself does not instantly disarrange this order. I found a guillemot near the cliff edge which had lain stark and stiff for more than a day and night, and exposed to rough weather. Yet the plumage was close, smooth, scarcely ruffled about the back and chest.

The pigeon's feather, which we pick up in the wood and carelessly drop, the single shed feather is a wonder of design; but what, then, of the whole plumage, and its symmetry and softness, its adjustment, its sustaining power in the air, and often its exceeding beauty of colour and chequer?

The extreme suspicions of the mallard flock, which is wallowing at the margin of the shallow lake formed by the incoming tide, are well shown by the telescope. There is a seagull on the spit of sand by the lake. I do not notice anything peculiar about this bird till I get the glass on him. Then I see he is running about close to the ducks with a long ribbon of seaweed in his bill; it trails on the sand as he runs, and a comic figure he cuts. He seems to have found a toy, and to be mightily pleased; there is no other explanation for this caper-it is not the nesting season, and the seaweed is not good to eat. But the ducks are as droll to watch, whilst this is going on, as the gull. They are startled from their dozing; every duck near the gull comes to attention. No doubt at first they are slightly alarmed; this passes, and they show signs 


\section{LIFE AND SPORT IN HAMPSHIRE}

of curiosity. The incident ends within a minute, the gull dropping and forgetting its toy. The ducks nerve themselves to their dangerous day-doze once more; standing on one leg, they fluff out their feathers, and snuggle away their heads into their own eider-down quilts. But the whole flock does not become headless at the same tirne. Some remain awake, preening themselves, or wallowing in the half foam, half water, or floating a yard or two from the edge, or even feeding - for ducks do find a little food on the shore and in the sea shallows, though their chief meat is on the mud flats at night inland.

The whole flock is alert; its sleep is the lightest; if every head were hid, the gunner still could not steal within range. But the ducks wide-awake are the more alert; and, danger threatening, they will scare the dozers as they rise, and the whole flock be up. Hence people persist in believing that there is a system of sentinels among ducks, the birds taking it in turn to doze and to keep watch; whereas there is nothing in the nature of such a very human arrangement among ducks; and there is none among rooks, curlews, rabbits. There does seem to be something of the kind among bees: the fierce guards at the entrance of the hive during the summer-how else can one account for them? But it is a sentinel system differing widely from that of men; it has no drill or discipline enforced by any officers or authorities in the community. There is no system of changing guard 
- this is essentially a human device. Is there challenging? I think not. The bee that does not come to the hive on legitimate business is recognised for a foe at once, and driven off without parley. A guard then there is among bees, and in a strong hive an efficient guard; but its composition is obscure; I do not know whether a bee guard is a honey-gatherer one time, a soldier another, or whether it is born and dies a guard. A delicate experiment might answer this question; if the bee-master could mark a number of guards one day, and watch another day to see if his marked bees mounted guard again, or came to the hive with honey and pollen, our knowledge would be increased. Exceptionally, no doubt, many honeygatherers become soldiers; but this is when the hive is attacked and there is a general resort to arms.

To return to the sea fowl's toilet. Even with the self-acting machinery of feather arrangement by which the plumage adjusts itself, duck or cormorant will spend over an hour a day grooming itself. When not dozing, the wild ducks, indeed, by day have little else to do on sea or sand than preen their feathers, and by toilet, scrupulously nice, keep themselves free from evil parasite. The fishy cormorant does not seem the bird to be fastidious in toilet. Yet we may do the cormorant injustice. When a prisoner, he appears to have little sanitary instinct as the nesting starling and other birds have. But often in a wild state, nearly an hour at a stretch, the cormorant will comb 
140 LIFE AND SPORT IN HAMPSHIRE

himself by the sea edge. Get a glass on him when he sits or stands, the water just curling in, and at each wash covering his large splay feet. "Jacky Cocktail," as fisher people call him, is hard at work on his toilet. He will shake himself like a horse or dog; and, the feathers after each shake falling back into their proper places, he will preen and stroke them. Does he oil as well as smooth them? This is a question which nobody has answered with absolute knowledge. A bird has oil glands, but are they used for dressing the feathers? Wild ducks' feathers, when lying flat and in their right position, are impervious to water. The water slides off as if the plumage were oiled, and perhaps it really may be an oil-skin coat the duck has on.

But many sea and river fowl are naturally oily. May not the oil exude from the whole body of the bird, more or less, and thus grease and waterproof the plumage? The idea of the bird squeezing a little pomade from vessels in its body, and applying this with its bill to the feathers, seems to me rather fantastic.

Sometimes the cormorant will stand for a full five minutes, his wings spread out; now the wings are still, now kept moving gently, as if the bird wished the refreshing, cleansing sea breeze to pass through them. The cormorant's favourite resting spot, however, is not the edge of the open sea: that seems to be his toilet haunt. He prefers those gloomy stakes by 
the harbour bar, covered with back blue mussels and bits of hanging seaweed. I wonder do the stakes ever rot away and need replacing? Who planted them there? And must not they be, through the preservatives of the salt sea, hard and seasoned as bog oak? These forlorn, and in some aspects even terrible, stakes are such things as a cruel dream might offer a shipwrecked man-he must drown unless he can seize and clamber up one of these black, dripping piles, slimy with weed and sharp with edged shell-fish that cut like jagged knives. These stakes are never wholly out of water in any estuary I have seen. Even at lowest tides the water laps round them, when the banks of the estuary at its narrow neck slope down dangerously, and the dry sands are hollowed and hillocked into odd configuration. Here the sands take the form of a raised geological map; there they are scooped into stalactite caves, dripping crystals, or carved as some Gothic decorated architecture. 


\section{CHAPTER VII}

\section{THE ANGLER}

LoNG before I cast my line on Hampshire chalk streams I had practised the art, which belongs to Hampshire before all other places, of taking a trout with a single floating fly. I learnt it largely through watching and fishing with the greatest angler I have ever known, Frederick Pigou. Angling with him on Hertfordshire streams, and often by myself on a Kent stream and the Derbyshire Wye, I came to understand a good deal that is necessary for taking large, shy Hampshire trout. But years before casting an artificial fly, wet or dry, an intense wish to angle for trout in a clear water had hold of me; and that in itself is training, an early education in angling. It is hard for some of us to remember days when we were not stirred by the spirit of angling. I recall a long drive of thirty or forty miles across the Berkshire downs into Hampshire, and how, breaking the drive at Hungerford for food, my two companions, both elderly men, stopped at a bridge on the Kennet and asked of one another whether the trout could not almost be smelt there. I think I might have dreamt trout that night. The sensation of looking over one of these old 
bridges and watching the ribbony wave to and fro of the bright weeds, and admiring the perfect clearness of the water, is one of the most delightful things in the experience of an angler; it appealed strongly to me even when the idea of ever rising from the humble class of baited hook and float to that of fly-fisherand for such splendid trout as these streams heldeould hardly have flitted across my mind. One of my companions then was going to fish in the Anton a day or two later; and I chanced to be on the lawn at Enham House where he was staying when with complete happiness he brought out after his sport two trout on a dish to show his host and friends. I had never seen trout so close before. They seemed immense fish-though probably not more than a pound and a half each-after the half-pound dace and perch I had been catching in a Berkshire stream, the Cole, with a worm and a bamboo rod-fitted with hairpins for rings. If they were taken from the head waters of the Anton a mile or two distant, Shepherd's Spring, he must have been a very good angler. Shepherd's Spring trout, I should say, are as hard as any trout to take. Small streams are sometimes easier to take trout from than large ones; but $I$ think it is not so with those mere ditches through the pastures: to cast a line on such tiny waters is to scare the trout unless the day is full of wind and rain. He really is the master who can so manage his tackle and so understand and study the trout as to succeed in 


\section{LIFE AND SPORT IN HAMPSHIRE}

spots where the fish hardly rise at a floating dun for days together, feeding instead on the water shrimp. I think I did once try to angle in this water some years afterwards-using a casting of three or four Norwegian lake flies! but the trout would not suffer my strange lure to come near them. I thought then, and I may have been right, that they were not trout that had thought of flies

Wherein is the thrall of angling with a single fly for trout in these clear brooks? Of course the summer scene by the chalk stream counts high. It is a scene good to eye and nerve and brain, every mile from source to sea; and the beauty of the whole, as the summer day draws to a close, has enchantments subtle, supreme. Bransbury Common near nine o'clock on a midsummer eve, with not a human figure in sight, and the mists, winding-sheets for the dead day, beginning to lie over the marsh-what a scene to rule us as we turn homeward! But apart from the scene, this fishing has a hold over me, powerful and persistent. I have found nothing quite so absorbing throughout an entire and a long day in other field pursuits, nothing that has so masterful a thrall. Hunting must be full of stimulation through the splendid exercise and high spirit of the chase. Angling for a rising trout with a floating fly has not this quality. Is the charm of it kindred with that of shooting driven partridges? To shoot these birds means many minutes of strong interest and excitement 


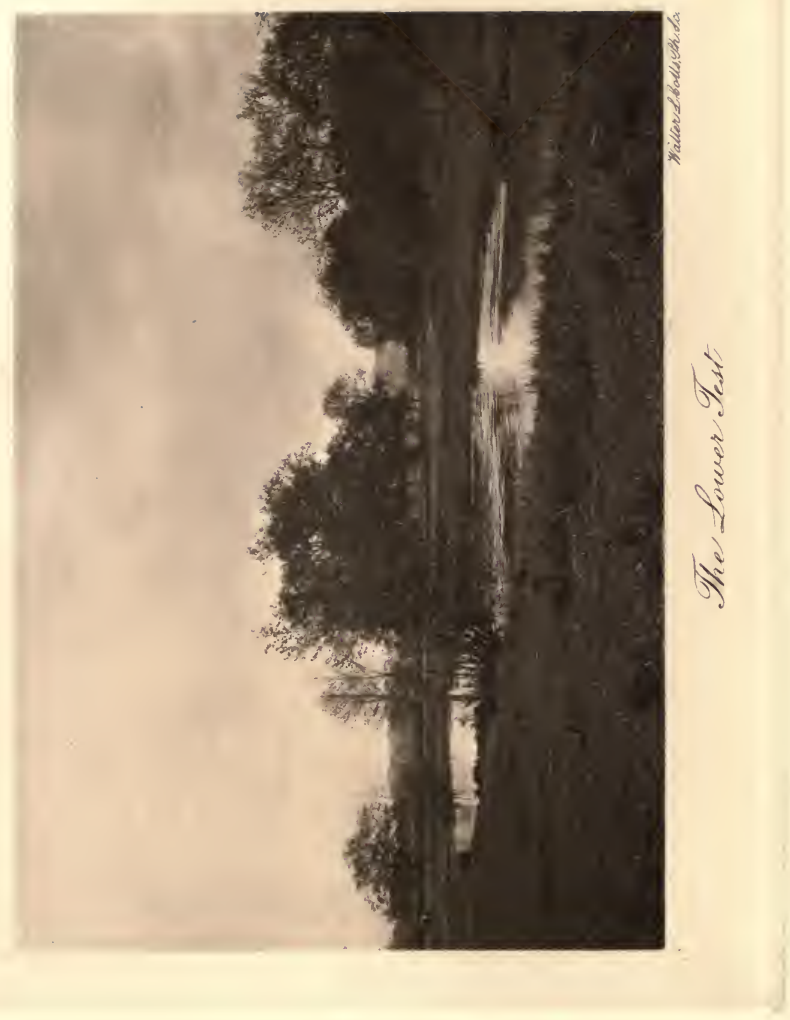



in the day. Minutes of packed expectation those are when the whistle sounds a field or two off, and you come to attention! The partridges are up-perhaps coming bolt for the bit of hedge allotted to you.

They must be gathering pace at every yard between the line of beaters and that hedge which cuts the world in two and hides all on earth you care for at this instant.

They ride perhaps on a ravening wind that adds speed to speed. At what point of the hedge twenty yards in front of you will they appear? The eye, in exquisite suspense, may rove along the hedge top looking for the compact, rushing covey that will sweep by with the force and decision of a powerful machine, or for the single bird that may be on the skylinelooking so embarrassingly small! That single bird topping the high hedge in the gale; how unsuited for your gun he often seems, if things have been going awry! There is a little world of space to miss into, and only this small, uncertain body-here one second, out of range two seconds later-to hit. Fear, hope, triumph, humiliation jostle each other in these tense moments. So that the most living moments in shooting are equal to those in fly-fishing. But in shooting the thrall is more intermittent. In shooting, no one lives in the gun the entire day: whereas in fly-fishing on the chalk streams the angler does often seem to "live along the line" from start till close. Certainly one has felt this to be so on the Derbyshire 


\section{LIFE AND SPORT IN HAMPSHIRE}

Wye where the hatch of fly and rise of trout are somewhat more scattered through the whole day than on many waters. On our Hampshire chalk streams the hatch and rise are sharply defined, but even here one often hugs hope all day to find a good trout moving, even though only an odd fly here and there sails the stream. The beauty of the river scene touches us throughout our angling day; but during the active hour of that day--perhaps five or six hours out of a total of nine-we cannot be more than underconscious of environment. It is steeped into us without our being fully awake to the process. I do not think any earnest dry fly fisherman of the chalk streams would deny that, however great his love of Nature, the watching, stalking, casting efforts of angling must command nearly all the fully conscious part of the man. There are intervals, I grant, when the trout is at the back of the thoughts, and the scene and delicious influences of Nature by the river come to the front; and I will touch presently on these. But far longer in each angling day they must be in the background. We might not, I feel sure we should not, take so kindly to this angling were the scene less beautiful. Moreover the influence of the scene is so strong in all our recollection of angling episodes; it is felt years afterwards. Recalling our adventures with large and difficult trout, we always paint the scene in, and it gives pleasure. Yet the truth remains that during these adventures, and in 
the passages leading up to them-the preliminaries of the contest with this trout and that-we cannot directly feel, think of, watch Nature outside the foot of space where the trout lies. The actual angling absorbs the active and contemplative parts of us. What is its secret power? It is pleasant to take home or to the angling inn good trout. There is a little pride in the exploit sometimes, the pride of successful competition where there are friendly but rival anglers. But it is not this that makes the sport such a thrall. Nor is it that we greatly want the trout to eat or give away. Nor is it that dry flyfishing yields large bags. The bags are small. A brace of good trout from the Test is a day's sport enough for the keenest of us. After getting two brace I begin to feel I have had enough. A day that yields a very heavy bag of trout is apt to pall. The fish have been too eager, too easy. I suggest four reasons why the art of dry fly-fishing for trout in a clear chalk stream should be so curiously attractive. First, the angler is quite free of outside distraction. $\mathrm{He}$ is alone with his sport-to be in these rich water meadows in the deepest, fullest green of the summer is to be intensely alone, sometimes for many hours at a stretch. $\mathrm{He}$ can and does concentrate on the sport.

Second, he so often strives definitely and solely, for perhaps half an hour or an hour, to take a trout which he sees, owing to the clearness of the chalk 


\section{LIFE AND SPORT IN HAMPSHIRE}

stream: I have always thought this to be one of the chief attractions, if not the chief attraction, of dry fly-fishing. To me it means so much actually to see the trout, and I think it must be the same with most anglers. It is a contest, an uncertain duel, between a man's skill and a trout's suspicion or intelligence. To see the trout come at the fly, follow and examine it closely; to see the trout half inclined to take the fly, but not more than half inclined; to see him retire and presently perhaps come on again-this is a very sauce of angling. Of course we cannot always see so clear as this, but if we fish with a short line or one of moderate length, we may often see much of the game where the stream runs smooth.

Third, there is the difficulty of the sport. The more difficult it is, the keener the angler will be. This is why heavy bags of trout, unless the weight of each trout be very heavy, soon pall on us. The hard work which the taking of a single shy trout often means, the dashed hopes, the trout gone perhaps as we laid the landing-net in the water-these increase the charm.

Last, I think the delicacy of the tackle, and its cleanness and the little compass into which it can be packed, are to be reckoned. There is a refinement about this angling tackle to delight us.

Whilst trout are moving, or even whilst dun and 
Mayfly are appearing at the surface, and a rise of trout is hoped for, we can give little attention to wild life. Our feeling for these things then must be indirect or subconscious. But in the waiting hours of the dry fly angler's day, we can be very sensitive to the beauty and interest of the riverside. In the meadows and marshes of the chalk stream there are birds we grow familiar with in spring and summer. I have written of the bleating snipe and the wayward, wild-flighted "martin-snipe" in other books, but not of the redshank and sandpiper. The redshank is one of the most volatile of river birds. Every spring a few of these smart little birds appear in the lower Test meadows, and I have seen sandpipers there in later summer; but that they nest in the place has not been proved. If we come within a hundred yards of the spot which it frequents, the redshank rises on the wing, and for a quarter of an hour or more will go through its singular play of wing and voice. It wheels round in irregular circles, ten yards or so from the ground, with a plaintive, piping note rather sweet and pleasing, though after a time this may grow a little wearisome. Its wings are cleanly, sharply clipped out for strong flight, like those of the dunlin. All these waders with narrow, pointed and clipt-looking wings must be powerful in flight, fit for long journeys quickly accomplished; but in the meadows, when it is disturbed, the redshank does not greatly exert itself. 


\section{LIFE AND SPORT IN HAMPSHIRE}

It wheels round the intruder by quick, slight strokes, or half strokes, of the wing, which look little more than quivers; and, between these, the redshank, with wing outstretched or partly flexed, sails and glides.

A few minutes of this motion and it drops to the ground, and, standing on a hummock, watches the intruder closely, and, still piping, cranes its head and neck and bows or nods. When this redshank play is first seen in the water meadows, one feels almost sure it must have a nest near by and is alarmed and vexed by the intruder. I know nothing of the redshank at other seasons, but I suppose this wheeling exercise and these bows and nods and pipings are peculiar to the nesting time. Yet, I doubt whether the redshank play proves that the bird really has a nest in these meadows or has a mate here. Without a nest, without a mate even, the redshank may wheel and pipe and bow when disturbed. The passion of the season may be strong in him. Nightingales sing intensely, lapwings twirl and tumble, even if they have found no mates. They are in high excitement at this season, and anything sets them into music or motion: this might explain the play of the redshank in meadows where it is not nesting.

The sandpiper is one of the balancing birds-restless as any wagtail. Head and neck and tail are all going hard, almost at the same time; it is as if 
the bird were set up on finest wire springs. Without this action, the sandpiper would be distinguished, its lines are shapely, and the whole form comely and choice. But the lively movements enhance its beauty. To have a glimpse from a railway carriage window of one of these little white-bellied things, bobbing and flirting at the brink of a stream or lakelet, is to long to get out of the train at the next station, and walk back along the line to the spot.

Of all the problems in Nature that we turn over in thought, this one of beauty sometimes seems the chief. Beauty of form, sound, colour, and device in every direction; beauty soaring on every wind, beauty running in every water, beauty covering almost every scrap of earth in Nature-and in most cases not the semblance of a theory to explain it. I doubt whether there is any good explanation why some of our birds are so distinguished by these exquisite actions of body, tail, wings. If they were only or chiefly used for courtship, we might account for them so. But the blackbird, when he pitches after a short flight, does not make those entrancing up and down movements of his tail for courtship, nor have I reason to think the redstart quivers his tail to get a mate or please a mate. The sandpiper and the wagtail movements belong to the same class of unexplained beauty. After all, though we smile at their simplicity, it was natural enough our fathers should conclude 


\section{LIFE AND SPORT IN HAMPSHIRE}

the stars were made to light our night, the flowers to minister to our sense of beauty, the fruits and springs to refresh us. We have given up that idea, but hare nothing that quite fills the gap.

The peewit is our constant uneasy companion in these water meadows. But the great peewit scene is at dusk or dark. In March and April the peewits that are nesting about the drier patches and hummocks of the marsh will have a wild assembly, not only on bright days, but through moon or star-lit nights. It seems so natural that such scenes of night beauty should appeal to creatures inspired with the romance and rapture of the season of courtship and show. Thus at midsummer we think the dancing place and hour of the ghost moths perfectly in keeping with the occasion-the sensuous June evening, in the scented dusk, when the evening star was waxing as the afterglow faded slowly out, the beginning of a Midsummer Night's Dream.

Peewits often assemble, then, for their revel at the marsh on just the lovely night we might choose for an open-air play. Yet what are to us beauty of time and place considerations do not influence the peewit. He may be a little livelier on a brilliant moonlight night, because the light keeps him wakeful, but there is little to show that he enjoys such conditions of light and weather more than he enjoys the gloomiest-gloomiest, that is, to us-evening in February. Such a gloom settled on the fields and 
hills one evening in February, by the river Test. The vespers of the song thrush suddenly ceased when the church bells ceased, and by six o'clock the effervescence of the chink-chink-chinking blackbirds was over. To human eyes it was not darker than it had been five or ten minutes earlier, when hundreds of thousands of blackbirds must have been chinking and thrushes singing all over England; yet now the whole small-bird world was locked in sleep.

I recall that evening so well, and my walk up Bransbury lane by the stream. A change in the growing night, too subtle for my sense, or some unknown habit in the bird's life as to the duration of the evening music and preparation for rest, had brought a lull after almost an uproar.

And now the peewits were gathering fast for their night revel. I noticed them first, before the light had quite gone, pirouetting over ploughed field and fallow above the water meadows. They were still there, later, when I could only catch a glimpse of a bird where now and then a wing flung above the skyline. Soon after, these peewits were drawn to a large meadow on the other side of the valley, a meadow-with all the hatches in the stream down -brimming and soaking with clear water from the chalk fountains of the glorious Test. Here, perhaps from presence of food or promise of nesting quarters, the peewits gather at night. Here, with voices of plaint and pathos, they toss and fling, and wildly 


\section{LIFE AND SPORT IN HAMPSHIRE}

scud along close to the earth, at a great pace when they choose-which is often-and the whole river valley, though the river itself scarcely ever grows in sound from lisp to ripple, is vocal. The mallard rides the water in this meadow, quacking hoarsely; the loud, sudden cry of the moorhen breaks out. It only needs cronk of heron and whinney of grebe to complete the familiar yet never familiar concert in the river valley. The snipe is a-wing. His startled "chuck, chuck" comes from the gloom above, and once even his distant bleat. This is the most alluring and mysterious of all bird sounds which these water meadows have; but the other sound, too, is full of charm, though, when syllabled, it sounds tame. This is the one occasion when $I$ have heard the snipe bleat during the first passage or grey of night; with full night, though I have often listened for his bleat in spring-time on the marsh, I have never heard it; but the startled cry, and, no doubt - though one cannot see it then-the erratic flight, are constant.

By seven o'clock all the peewits of the neighbourhood seem to have been drawn from their daily haunts to the large water meadow, and their cries, as they toss and whirl, are as thick as those of a gathering of gulls. The hills above the valley, the whole landscape, indeed, have been blotted out by mists, and the air and earth are reeking with damp. A gloomier scene one could not imagine, or one 


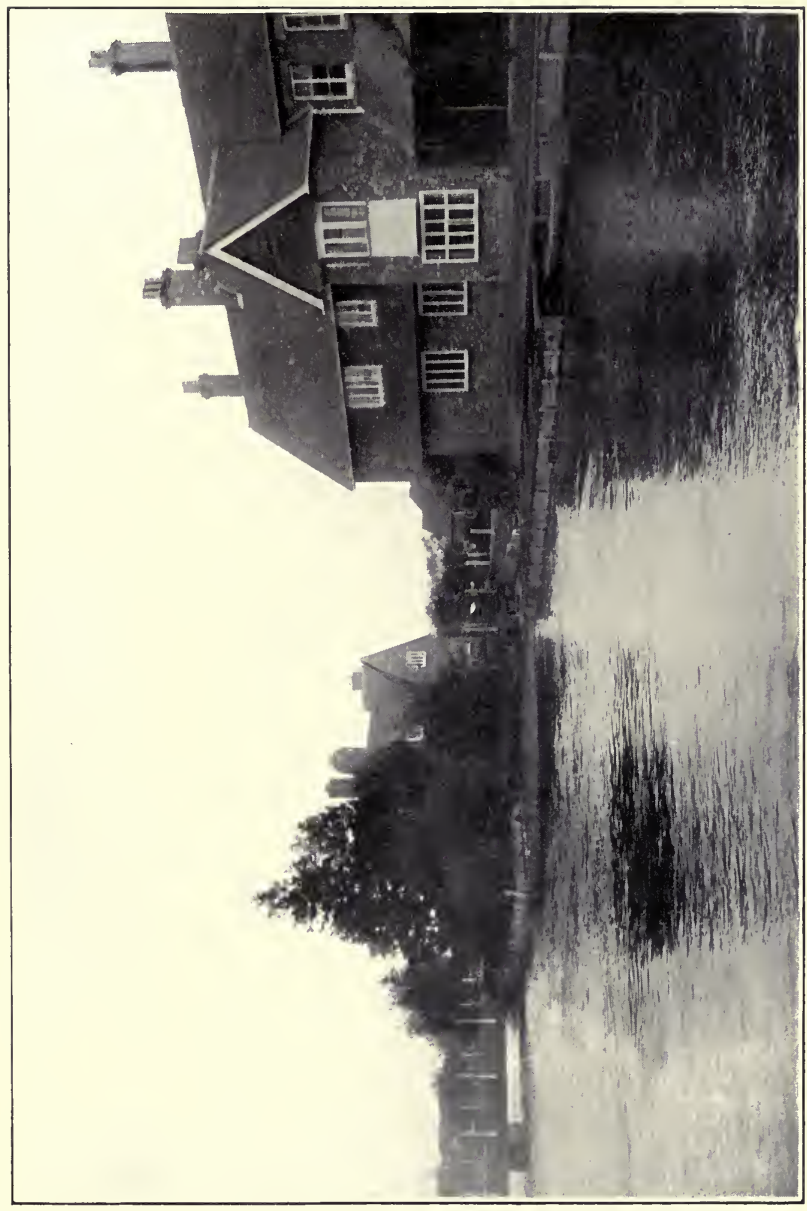

佽 

that seems less fitted to the rapture of any living thing. The sad, waste spot, which the song of the dying swan woke to joy, could not have been sadder than this. Yet, turning home with the longing for light and warmth, I thought I had never before heard the pæan more joyous.

An astonishing thing about the lapwing flock in winter is that without organisation it should yet move with the order, punctuality, simultaneity, which in human societies can only be achieved by perfect organisation. Rooks display the same qualities as the lapwings, but as rooks spend their lives in flocks, it does not strike us as so astonishing in them. Rooks are always in practice, working together. The lapwings live out of the flock half, or more than half, the year; yet young and old alike-young that have never lived the flock life before-no sooner collect in the autumn than they are drill perfect. Their movements have not the variety of the starling flock; they do not cut that wonderful series of figures in the air; but for bird simultaneity I think they are surpassed not even by the starling. It is good to be a hundred yards from a great flock of lapwings in December, five hundred strong, perhaps, when it comes down into the ploughed field to feed.

Acres of ground, where the lapwings settle, begin to dance and quiver with black and white!

Even on a dull morning this is a very pretty thing to see; if the sun came out the white would 


\section{LIFE AND SPORT IN HAMPSHIRE}

shine like satin, and one might get shot hues of green and blue beside, for the gloss and the "interference colours" are a feature of the lapwing even in winter dress. Suddenly the five hundred is off the ground; but is suddenly down again-a false alarm. A little later they are really up and away, for somebody is coming across the footpath at the side of the field by Oakley Station. One lapwing did not rise first, or two or three at the outside nearest the intruding figure; the whole five hundred rose as soldiers-regulars-at the word of command. I do not say that the five hundred showed quite the simultaneity in coming down on to this field that they did leaving it; sheets of twenty or fifty birds at most, perhaps, came down at the same moment, and even a few stragglers which had failed to swing round in time when the flock made up its mind to alight in the field, were nearly half a minute late: one of these, as it came sweeping round, gathered pace, and made as though to buffet an unoffending rook feeding in the next field, but swerved aside, and passed on, thinking better of its first wanton impulse-so like a bird's hostility! But though all did not settle in the same second, none fell out of the flock in the course of the wavering, fluctuating movements that led to a general settling on this ploughed field.

I have shot with my old friend, the master angler, 
Frederick Pigou, in these Hampshire fields, but never angled with him there, though once he knew them well. All my fishing expeditions with him were farther north or west. May was his chief month for the trout, though April brought him many a heavy basket from chalk streams, where he would often fish with one large fly, the alder. There are anglers who think this style of fly-fishing for trout not feeding at the surface poor, even doubtful sport; but no one who watched our friend working his favourite alder fly across and down stream could hold that view long. He far excelled any angler I have seen at work in this way of fishing, and I have known him take large shy trout in finest water, its surface smooth almost as a mirror. Casting a long, clean line, he would, by gentle, even movements of the wrist, make the fly zigzag across the stream in a way that tempted the fish greatly.

After all, though, we shall remember him most for the ease and grace and the success with which he drove the single floating fly, tiny dun, or large May fly, to the rising trout. It seemed to me as if the wind had little power to crumple up his line or turn it from its mission; and yet all was done so easily, not a fraction of effort misspent or misapplied. Another thing about the angler was the way he would walk by the river or stand to cast without alarming the trout. It was as if he and his rod were invisible to fish: the wave along the 


\section{LIFE AND SPORT IN HAMPSHIRE}

glassy stream that marks a large trout in flight before an angler's shadow or figure or rod would be rarely seen when he was standing or kneeling by the stream and aiming his line. One might have fancied him part of the natural scene, at which wild creatures would no more take alarm than at straying cattle in the water meadows, or birds flying across the stream. He seemed to fit naturally into the landscape.

His favourite trout were the very large, solitary ones which live in sullen little backwaters, or weedy ditches that fed the river. He believed that the heaviest of these back-stream trout which he had hooked was one he tried for a few minutes after I had landed for him the five-pounder. We could see the fish roaming about the shallows; its back and bulky shoulders, and now and then its tail. He hooked this great trout, throwing the fly with his left hand right under his own bank. There was a plunge and splash, the hook came away, the trout of a lifetime was gone. But another time, with the usual gossamer cast, he took a trout of six and a quarter pounds weight in broad daylight by the railway bridge. $\mathrm{He}$ told me it was rising close to a hawthorn that overhung the water, and he had to send a long line down stream, and let the current "drift" the fly over the trout. This, perhaps, was his masterpiece. He remembered it with more interest, I think, than many a basket of trout weighing 
over twenty pounds at the height of May fly season. But as for baskets, sometimes he would neglect to carry them. One day in spring we set out together with rods and flies, but without basket or bag, and between us we got over twenty pounds' weight of trout, the largest fish scaling two pounds and a quarter. We had to carry them home strung on a twine. To go out with the master angler often led to some incident like this. As to provender, our friend was rather careless, being content if he could buy a loaf and a bit of cheese at the village shop on his way to the stream; but nothing would induce him to start unless his tobacco-pouch was well packed. It was the largest pouch, surely, a man ever carried in the pocket, almost big enough to hold a pound trout.

In half a century he had angled in nearly all the best trout streams in England. There was one very small, clear Hertfordshire brook, a glittering thread through the pastures, whose headwaters you might say he discovered. I fished this water with him, and he would point out the spots where he hooked the heaviest trout during the first season he angled in it. It was then a wilderness, overgrown, overlooked. Nobody thought of angling in it, though at hay harvest the field-workers might spear a fish or two. $\mathrm{He}$ found very few trout in the brook when first he angled there-but these few very heavy; they fought desperately hard in the weedy water, overhung in places by trees and bushes; he remembered there 


\section{LIFE AND SPORT IN HAMPSHIRE}

were about twenty trout to capture during his first year there, and they averaged four pounds each in weight! One of the largest leapt clean out of the water when it was hooked; the old angler's companion coming up, found him plunging about in the rushes and swampy grass by the edge of the brook, grabbing at a great trout which seemed likely to leap back into the water. It was the wildest sport the master had ever known, though he fished for salmon July after July in a remote part of Lapland. Sometimes he had to start for Lapland at the height of the May fly season; and once, at the end of May, he had to take to pieces his rod in haste-having fished to the last possible moment-and haste away to catch his train; a few more casts, and he would have lost the train and the boat to the far north. The trout at the moment were rising well at May fly, and his creel was weighty.

Some anglers are not quite happy with the May fly. They find that it often fails them. In a fair season I never knew it fail the master angler. In one water, where the trout ran very heavy, he would return any fish under two pounds if there were a heavy rise at May fly: he was the least greedy or anxious angler.

We hear or read of a few people who step quite naturally into a career of statesmanship, clearly are born to the purple of it. I imagine my friend began naturally a great angler. His exploits, about which 
he was so modest and unknowing, might go down as classic. He was the most natural stalker and hunter of wild things one could imagine. Caring nothing for personal ornament, he was never dressed out for sport. Clothes, he held, were to keep us warm in winter, cool in summer; the cut of them should be for comfort, solid use. This principle he applied to boots, hats, everything. He would have thought it infamous to put polish or blacking on a good pair of boots. His boots, carefully greased, never let in water; his clothes were proof against the roughest places in wood or by river. For changes in fashion he cared nothing; he did not scoff at such thingswho of his friends ever knew him scoff at anything?he was serenely unconscious of them. He was one of Nature's sportsmen; and his was one of those human figures that may add something to the charm of scenery. Where shall we find another angler quite to equal him in skill and modesty and memories of great trout and salmon days? 


\section{CHAPTER VIII}

\section{INSECT LIFE}

How delightful in a winter evening's reverie over the wood fire to think back the butterfly days of a great summer! I feel now, as I felt long ago, that the freshest of these butterfly days in the wood, days with none of the exquisite bloom of the new summer lost, are when the pearl-bordered fritillaries first appear. The two little fritillary butterflies are on the wing in such scented, sappy hours, when the cool of the rain, and the heat of the sun, in perfect unison, do make days of a wonderful refreshment. Though the orange tip butterfly in some years is not a-wing before the copse fritillaries, it is on the whole a little earlier than they. I look for the orange tip just after the azure-blue butterfly and just before the fritillary. In $1906 \mathrm{I}$ found it out in numbers as early as the 6th of May; and in that year I actually saw an orange tip flying on the 24th of April -in London!

Hot sun alone does not, I think, ripen and release from its wrap the orange tip butterfly. It needs hot sun shining after or between the showers-that 
delicious blend of moist and dry which in May we talk of as growing weather. Year after year I have noticed that the orange tip butterflies appear on the wing at such a time.

The orange tip seems a pretty illustration of that flight by the "waved track" I have spoken of. It makes, for its feeble-looking flight equipment-limp and thin body and wings without stiffness or cutting power-rather quick headway, driving itself forward on to the crest of its wave of motion, and at the end of each stroke, or, rather, at the end of each journey -a foot, perhaps, in length-which the stroke results in, there appears to be what I suppose might be called a dead point; the crest of the wave, that is, ends in a point, and then a fresh stroke of the wings (all four wings act together, of course) is delivered, which jerks the little butterfly forward till it reaches the pointed crest of the next wave.

Jerk is rather a distinct feature of the flight of the orange tip; the strokes do not appear-though our slow sight may well be tricked here-to glide so smoothly, imperceptibly into each other as we know they do in other forms of flight; for example, in the figure-of-eight hover of the kestrel or the sphinx moth. But, though the orange tip looks so ill equipped to face aerial difficulties, he must fly many miles on a hot and fairly still May day. He is up and down the sunny field side or the turf by the road scores, probably hundreds, of times between ten in 


\section{LIFE AND SPORT IN HAMPSHIRE}

the morning and three or four in the afternoon. $\mathrm{He}$ must cover, surely, fifteen or twenty miles a day, and the slight breeze-against hard wind he is helplessis not always with him.

The orange tip often is no seeker of the sweets that Nature packs the flowers with in May and June. On the opening day of its season I may not see it once alight on.a blossom and probe for nectar. The seeming object of this lovely butterfly's parade is to find a mate or a rival, or to fly for pleasure of flight in the sun. No orange tip bears another orange tip or a sulphur butterfly to pass within a few yards without flying up to examine the stranger. An orange tip flies to a sulphur, all but touches it, but in less than an instant knows the stranger is not of the orange tip species; so the two part without showing the faintest interest in each other. That odd teetotum twirl, the butterflies revolving round each other several times, only occurs when orange tip meets orange tip, or sulphur meets sulphur. If the search for a mate is the sole incentive that drives the orange tip many miles a day up and down the field and roadside-he loves a long strip of rough grass between the road and the old high hedge-if nothing else in the insect world of feeling and motive enters, then Nature is rather leisurely in accomplishing her work here. Why days and days of flight in search of a mate, why all this exercise up and down the field and roadside, a hundred journeys and more made 
without result? But I am not persuaded that other incentive, other motive, may not be working with the orange tip; and that a sheer ecstasy of exercise on these delicious days, as well as the passion for a mate, may not move the butterfly.

In June, when the pearl-bordered fritillaries are out in numbers, it is a pretty thing to see their frequent courtships in the coppices among bugle flowers and speedwell. Watching orange tip butterflies and the common blues, one sees courtship almost exactly similar. An orange tip male will pursue the plain white lady of his possible choice-possible only, for quite likely he will jilt her after all. Perhaps the lady will have nothing to do with him, dodges, shakes him off. But more often I have noticed her satisfied with him as her suitor. First she may appear coy, but soon she ceases to fly; she settles on the ground; he settles near her. So, in the sun-for there must be sun, I think, for orange tip courtship-they sit. One feels sure it is a match. But no! Two minutes or less, and he suddenly rises, forgets all about her, is off seeking a new lady, or new honey blossoms, or whatever it is he does seek on these errands up and down the fields and hedge sides. She discovers in a fow seconds that she has been deserted, and is up and away too. Often I have seen this curious little play among orange tips, and once or twice (at Brockenhurst in the New Forest) among common blue butterflies. I an quite sure that it is the 
orange tip that has refused and left the lady, not the lady her uncertain suitor.

Midsummer!-and with it once more the ecstatic spin of the ghost moths! Three years I have watched the moths in the meadow, and the charm of the mystic thing seems more and more. The same scene each June-yet a scene that, for any sense of familiarity there is about it, might be wholly new. But even looking at the thing quite objectively, some incidents or details not noticed before will present themselves each season one watches the ghost moths a-wing. The first evening I watched them last June a strange figure was on the scene. At nine the barn owl came stealing out of the wood-dark to hawk the field like a great spectral swallow. I have seen the nightjar doing this once, but the effect produced by the owl was stranger and more beautiful. Often twisting slightly on the wing, he would flash white as the sea-fowl in the sun; and, with the moon high and nearly full-between egg-shape and perfect round-I could watch him from one end of the field to the other, and even see him as a white spot on the fence at the far end, three hundred yards away, when he settled to rest a few minutes.

It was not a June air or sky, and not June's breath and colour, with the moon gleaming through a rusty zone, and with a hard wind having something of the east; yet there was a wanness of light and a movement that went well enough with the ghost moths' 
dance. Watching the white owl hawk the heavy grass field in three evenings, I doubt not he came for the ghost moths. The owl, then, is insect-eater at seasons. I was never near enough to see him seize a moth, but, his movements left me in no doubt the second evening. He would sweep just above the flowering grass heads, stopping dead here and there, hovering for a second or two, dipping slightly, then, mounting again, sweep onward. His flight, every twist, every stroke of it gave me the idea of downy softness and downy silence; and of smoothness and ease too, though not of a great power of speed. Twice or thrice I saw him swoop upwards a fow feet above the grass heads, and then he must have been taking a moth that had mounted high and was zigzagging away to another sphere of action, as the ghost moths will.

I went out to look for the white owl among the white ghost moths on the fourth evening, but he did not appear on the wing whilst I watched. A fine rain fell, little bursts and whiffs of wind from the southwest urging it almost horizontally. Even during the whiffs the ghost moths were up, dancing above the grass heads. I thought at first they danced with a little less spirit than on dry evenings, but this may have been fancy. Wind and wet must be furious, I suspect, to keep down the ghost moths the whole of one evening. The first evening I saw them they were moving with their wonted energy, though the heavy crop of grass rustled and bent low before the constant 


\section{LIFE AND SPORT IN HAMPSHIRE}

bursts of a strong wind. They kept up by dancing with their heads pointing always straight into the wind-just as the hawk hovers. Mr. W. H. Hudson once remarked to me that the whole outlines of the ghost moth's wings are clearly seen as it swings or hovers, and I thought this might be because the wings did not move so quickly as those of other hovering moths-whose wings appear to the eye only a misty semicircle as they spin. But, watching again, I incline to think that the action of the wings, after all, is intensely quick, and that the reason why the whole outline of them is seen clearly during the spin and swing is that the white of the wings is so strong. So lustrous white is the male ghost moth that several times I have mistaken for him one of the ox-eye daisies bobbing in the wind among the grass heads; and likewise have mistaken a dancing ghost moth for a bobbing ox-eye daisy. This is an amusing little deception. It might strike the imagination as a whimsical bit of mimicry prepared at dusk by midsummer fairies, just to tease a gross, clumsy man; an illustration of "What fools these mortals be!"

Now when the female ghost moth spins and swings. the outline of the wings and their disposition are not so clearly seen, nor cleanly clipt out in the air, as with the male; the misty semicircle of wings, which we notice in the common $\mathrm{Y}$ moth hovering, is to be seen when the female ghost moth is spinning and swinging. The difference between the male and the 
female in this is due, I think, simply to the fact that he is so satiny white, whereas she is somewhat sombre in dress and presents no striking contrast with her surroundings.

Watching individual ghost moths of both sexes closely, I find they will often dance over the same yard of ground, meet and pass each other without act of courtship. A male moth is spinning and a female comes spinning past him; or the male spins past the female; and yet, again and again, I have noticed, these ecstatic dancers take virtually no note of each other. There may be a trifling sign that they see each other, nothing more; and they go on with their weird exercise, quite unconcerned by each other. I do not say this is always so; but very often; and it is conduct such as this which feeds the doubt in my mind whether the general and accepted theory is enough that says: "The only aim and end of an insect performance like this is sexual; the moths dance to attract each other's notice." May there not be an ecstasy in it over and above motives of attraction-over and above Nature's plan of Utility?

I find myself almost alone in questioning whether Utility accounts for all these mystic and charming scenes in the drama of wild life. I alone seem to doubt whether Utility is the Be-All as well as the End-All of an insect's dance, a bird's song, a flower's colour or pattern. Everybody seems ready to set it all to the giant credit of Utility. I recognise the huge 
compelling power of Utility. But I cannot see its rule clearly in all these matters. May not pleasure for pleasure's sake exist in the insect world? May not play for play's sake exist there? The sports or relaxations of insects-at first thought this may seem a fantastic idea, a humanising of creatures whose sphere is utterly alien to human. But is it so fantastic? I am not quite sure. The conduct of the winter gnats and their summer relatives is very hard to account for if wo rule amusement, pleasure for pleasure's sake, out of the insect's world. These are the gleaming-winged, almost diaphanous, little things which, at varying heights from the ground, keep rising and falling, hour after hour, in sunshine and sometimes in shade-and even in rain. They are said to dance in the form of a column, but, if so, it is a leaning column, for the rise of the gnat is nearly always at an angle-it does not mount straight up, though it sometimes may drop straight down.

Often in summer immense parties of these gnats are seen rising and dropping in a mazy confusion over the top of a fair-sized tree. But the gnats that dance in winter and spring are more often seen at about our own height from the ground. These little dancers dance, I imagine, very near the place of their birth. They are hatched in the ditch or turf by the side of the hedge, and here they live, dance, lay their eggs, and die. This is my notion; but I have never followed the career of a gnat in its metamorphoses. 
The gnats do not always dance in parties large or small. A single gnat will rise and drop within a foot or so of one's face for several minutes at a stretch; then perhaps sink to the ground, take a short rest, and spring up to dance again. Though we can interrupt, or even disperse, a party of winter gnats by walking through them and waving them aside with the arms they seem to have little fear or consciousness of our existence. Soon they will reassemble at the spot where we disturbed them. They are not on the alert like a house fly or a butterfly. At most, perhaps, they are a little more conscious of our presence than would be the water flies or ephemeridce, such as "duns" and "March browns" of the angler. Our forefathers, watching the dance of gnat and of spinner or full May-fly, by the river, would say without hesitation that these insects were simply enjoying an ethereal exercise in the sun and air. "Mark," they would argue, " the goodness and kindness displayed in all created things, and how even a gnat can enjoy to the full its little span of life!" But a generation ago we changed our views about these matters. We come to see in such a dance only a display, a device to preserve and increase life; the dance would be then merely utilitarian courtship, a practical search for mates.

Is it, however, only this practical search for mates, an advertisement of gnat to admiring gnat? This is what we have never proved. Kirby and Spence long ago pointed out that the great majority of these gnats 


\section{LIFE AND SPORT IN HAMPSHIRE}

were males; and certainly courtship between the sexes may often be looked for in vain, though we pass from party to party of gnats along the side of a sunny hedge. Dancers are constantly falling out of the dance and sitting on the grasses or the ground, to resume after a few minutes' rest. So it goes on for hours; as late as six on a February evening I have seen gnats dancing. Might not utility's end be served easily and surely enough without all these hours of mazy motion? This is a doubt which will present itself whenever I watch the gnat parties. It persists, too, in presenting itself when I watch the toss and swing of ghost moths, though there courtship is oftener noted than among the gnats. And when a gnat keeps up his dance till near twilight, with no companions, can we believe that mateship is the only motive?

After all, love of amusement, pleasure for pleasure's sake, exists among various mammals, and-so I strongly incline to believe now-among birds; why not among insects? Utility is dominant, no doubt, with all life, the master magnet by which men, in the lump, are only a little less powerfully drawn than the rest of creation. But we need not in thought imprison the insects or birds still closer in a Coke-town of utility than Nature herself keeps them. The honey-bee may never indulge in "idle pleasure," but I am not sure of the dancing gnat, the butterfly in its ecstasy of sun, the moth in the 
charmed twilight. Granting that the butterfly opens and shuts its proud wings to draw attention of possible mates-utility-and that these winter gnats dance in male parties to commend themselves to the other sex-utility-it is still possible to think that other motive comes in, and that amusement or pleasure for its own sake is this motive. Birds sing to draw mates-utility-but often there are other motives in singing, and one of these surely is pleasure for pleasure's sake.

I leave utility, and turn back to these summer sylphs, whose every movement seems to argue that beauty and pleasure are paramount. Save for their impulses of migration, most butterflies are essentially home-stayers. An acre of ground is enough and to spare for a butterfly, enough for a moth. The sallow on which the purple emperor fed in its grub stage of life may serve as its throne when the chrysalid grows into the perfect insect. A few yards of ground are enough for the small heath or the large heath butterfly, if it has a few flowers to draw nectar from, a bent or a grass-head for a night couch, and the plant-food at hand for its caterpillar descendants. The marbled-white is another home-stayer. But this beautiful butterfly is curiously local, not only as individual, but as species. I forget what the caterpillar of the marbled-white feeds on, but it is a plant that grows in abundance in thousands of places where never a marbled-white is seen. With a fastidiousness 


\section{LIFE AND SPORT IN HAMPSHIRE}

marked even among fastidious butterflies, the marbledwhite inhabits certain strips and patches of ground, appearing here in the winged state summer after summer, and not spreading through the country around, though the food of its caterpillar grows in plenty. Through old experience-for the marbledwhite was one of the first butterflies I watched in our Hampshire highlands-I have come to know a likely bit of ground for this insect, and to predict with some confidence whether it will be found there. A fairly long strip of turf by a branch road through the chalk downs and valleys, alongside it a tangle of yellow bedstraw, rough, tall grasses, knapweed, and scabious, then the hedge with the cornfield beyond-this is the place for the marbled-white. There is a strip of this character in North Hampshire which for several years I associated with the marbled-white, but, not visiting the place at the right season, I only saw the butterfly there for the first time in 1907. It came on the wing late in July, though often I have seen it early in the month in our woods and common. The marbled-white flies up and down this strip of grassy waste by the road about four yards broad, and a hundred or so long, and rarely roams from it.

I put butterflies roughly into three classes of flight; those that cut through the air with clean strokes, soaring and sweeping along gracefully or powerfully; those that dart swiftly and zigzag-the skippers, for instance; and those that bob and toss themselves in a style that 
looks impotent. The cabbage-white and the greenveined white butterflies belong to the third class, like the meadow-brown and ringlet; and with them I must put the marbled-white butterfly, though it is patrician to look at, whilst they are plebeian. The marbledwhite with all its beauty, bold black and white wing pattern, so effective in motion and in rest, is a humble flier. Yet there are fine distinctions even among these humble fliers of the third class of motion that are worth noticing. Thus the marbled-white has a pretty if a small soaring action which I have not noticed in our common white butterflies. Sometimes, between the ordinary tossing, bobbing strokes, and when it is hesitating whether to settle or not for a few moments on knapweed or scabious, or when it is examining closely the ground among the grasses, the marbledwhite soars with wings not lying flat on the air, but about half flexed. The action is over in a few seconds, a trifling variation from the flight of my third-class fliers; but, whilst it lasts, it is a dainty little thing to see. Every minute detail and difference in wing work is worth watching.

The pearl skipper was a stranger to me when I first wrote of the wild life of Hampshire woods and hills. I have discovered him and the tiny Bedford blue as Hampshire butterflies within the last few years. The pearl skipper flies in the fizzing heat of the summer. In three Augusts I have watched him by the Kingsclere road as I have watched in three Junes the ghost moth's 


\section{LIFE AND SPORT IN HAMPSHIRE}

dance in the grass field. Each season there is something fresh to notice about pearl skippers, as about the ghost moths. The ghost moth seems to live without food. I have not seen a sign of its refreshing itself, though it belongs to the somewhat fat-bodied, substantial class of insects, and one thinks of these commonly as being feeders. Whether the ghost moth would " come to sugar" - the syrup of strong drink and treacle mixed by which the collector traps many moths-I do not know. But in nature there seems to be no sugar for a ghost moth save the sugar of love. In that extraordinary life, of which only about one twentyfourth (sometimes perhaps no more than one fortyeighth) is given to wakefulness and action, there seems to be no time or inclination for anything but dancing.

How different is it with the pearl skipper! When last I visited his patch of ground on the hillside-he seems as wedded to one little place as the marbledwhite-the sun was behind clouds, and only the common white butterflies, which are less dependent on sunshine than most others, were a-wing. But ere long the pearl skippers appeared, and this is how they spent their afternoon: they drew sweet-meats from the dwarf thistles and the lesser scabious, or sunned and showed off on the ground or on a blossom when the sun was out, and, when it was in, they closed tight their nattilycut and stiff little wings and dozed on the ground or on a low-growing flower in the turf. The process of sunning and showing off was always exactly the same. 


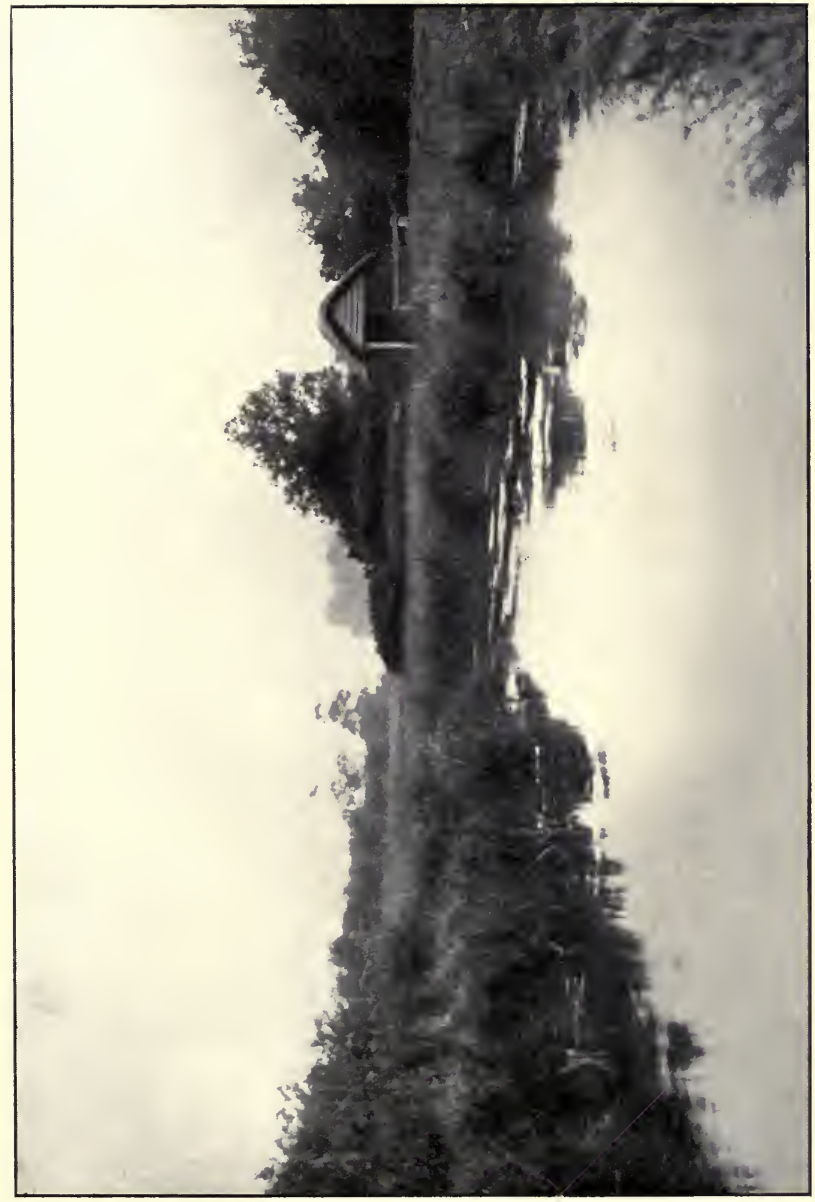

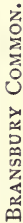



Each time a pearl skipper did this, it turned its back to the sun. It sat as a rule on the close, short turf, its tail always lower than its head, the upper part of the butterfly being raised clear of the ground by means of the legs. I suppose the pearl skipper was at an angle of thirty degrees from the ground, only the tip of the tail and the legs actually touching the ground. If it sat on a leaf or a flower the position was identical. The hind wings were separated from the front onesnot lying flat on them, as they do with many butterflies-and the four wings were slightly turned upward, about three-fourths open and one-fourth closed. This is the skipper carriage of wings. The small skipper, which I saw on the narrower belt of turf and juniper across the road, when sunning arranged wings and tilted up head and upper part of body in the same style.

A pearl skipper suns for a minute or two, then is up and off in a flash to a thistle or a scabious for a wee bit more refreshment; or it is off to sun on a fresh spot; or to dodge and twirl for a moment round another pearl skipper; and, as it whisks from sunning spot to thistle, it is often hard for the eye to follow it for more than half a dozen yards; suddenly it is lost to sight, being so quick and erratic on the wing.

It was only last year that I noticed the pearl skippers turning their backs to the sun when they settle and show off. The sun shines on the greeny fluff which covers the back and all the upper part of the body of the pearl skipper, and surely the effect 


\section{LIFE AND SPORT IN HAMPSHIRE}

on the little butterfly must be one of keen delight. The back turning to the sun was so invariable when they showed off-not when they took refreshment on thistle or scabious-that I can hardly think it unessential.

It is not, however, all beauty on the grassy Ox-drove where the butterflies play and sun themselves. They have sometimes a grim insect companion. Which is the most evil-looking of all winged creatures in England? I believe I have discovered him in one of the asiliform insects. I am not sure of the exact Latin name; there are several British members of his wicked group, one Asilus crabriformis, another Leptogaster cylindricus (names for a cork-lined box), but I will give him the shorter name Satan. People who have watched hairy asilus gripping his prey with the hold of a forceps and have looked at him closely in all his aspect of evil, will not quarrel with the name. Asilus is insect Satan, and should have for attendants the scorpion flies which visit us in late summer through the open window, drawn to light like a moth.

I first saw the insect Satan on the grassy Oxdrove, among butterflies and grasshoppers. Later we discovered another hunting-ground of his, a very rough farm road or track in the hills above the river, about half a mile from Ox-drove. This part of Hampshire is a land of thick, unshorn hedges, of little copses or spinnies by lonely branch roads. It teems with insect life through August. I have 
never known a land so favoured by grayling butterflies; on one bit of thin grass I have found the grayling almost as abundant as the meadow-brown. Asilus flew over the hedge and settled on the flinty road a few yards from us. It is possible, with cautious movements, to approach him closely. At a yard's distance we could distinctly see that he held, as in a vice, some small shining black insect from which he sucked the life juice. Flying off a yard or two, he carried with him his meat; and his partner, who soon came on the scene, had the same grip on her prey. In a few minutes both were gone, with a loud, sullen hum, but I had seen enough of them to revise a former impression. Satan does not, as I thought, sit with the powerful, hairy legs raised well above the ground; but squats almost flat, legs stretched on either side. Both sexes have the same rounded, humpy back and shoulders, but they differ in colour. That one $\mathbf{I}$ take to be the male is brighter yellow about the body, and I think he is slightly the larger. Both have long, thin bodies like those of attenuated dragon flies. My companion made from memory a little sketch of Satan, and could hardly exaggerate the look of ugliness and evil. Only the size of the creature prevents him being worldfamous; cast him on the scale of a bird, even a small bird, give him a sting able to wound a manwe should all be up in arms against him, and put a price upon his head. 


\section{LIFE AND SPORT IN HAMPSHIRE}

Save the lingering sulphur, the wall argus is about the last of the butterflies of waning summer. It is one of the insects that in flight I class between the mere bobbers-as meadow-brown, large heath, and ringlet-and the floaters and air-cutters, as white admiral and silver-washed fritillaries. It has very much the gait of the grayling butterfly, the halfopen, half-shut appearance of the wings in flight being notable with both. Often the wall argus has the appearance of the letter "V," a broad "V." A few arguses appear in our wood in August, but it is not their favourite haunt. The argus rather affects worn and dusty footpaths through the environs of townsa brick and mortar butterfly. It is content with the poor flowers which town fields and their rubbishheaps yield, and will sun itself there as in the flowery woods and fields we associate with bee and butterfly. Like the skipper, the argus must get its back to the sun whilst sunning. I notice that if it perches face to sun it will crawl round and get its back to sun ere it softly raises and lowers its "eyed" and speckled brown wings or takes on that tranced look peculiar to the sunning butterfly. The butterflies which I have seen turning carefully their backs to the sun are pearl and small skippers, common blue, ringlet, large heath, silver-washed fritillary, white admiral, and wall argus. Perhaps the habit is common to all English butterflies that sun themselves. 
The wall argus is a constant sunner; and it suns more often on the bare ground or short turf than on a seat aloft. But, though it is so fond of burnt, flowerless, and trodden spots, I find it on the heights by the sea near Alum Bay, where the air is steeped in scent, and the ground one grand purple with the heather; and it is a nectar-drinker. On these glorious heights I have seen the two or three common white butterflies flying in quite a fresh breeze, and am impressed by the progress they can make against the wind. They appear to do it by tacking across the wind, but even this is no mean success, considering the flimsy paper look of their wings. The whites, like the meadow-brown class of fliers, have wings that look as if they must be controlled by the air; whereas many insects-some hawk moths, for example-have wings cut and strongly nerved to control the air. Midway between those that look air-controlled and those that look air-controlling comes this wall argus, with the grayling and the marbled-white. But there are a number of smaller butterflies, the fast little blues and brown arguses and coppers, that it is not easy to fit into either class. A common blue's wing in cut and texture looks somewhat as if it would have no driving power-as if it would only be of use for bobbing and fluttering after the style of a meadow-brown butterfly. Yet the common blue is a quick and nimble little flier. It seems to progress by tack and zigzag; has 


\section{LIFE AND SPORT IN HAMPSHIRE}

no darting strength as have the skippers, its companions, and no floating or gliding movements on the wing. It moves quickly by a larger number of smaller tacks and zigzags than the slow, prosaic, meadowbrown makes.

Few things about butterflies and moths interest me more than the why and whence of their colours and patterns. To-day most naturalists believe that those colours and patterns not given them for sexual ends must be given for protection-a dress that brings them into harmony with, even mimicry of, their environment, and so hides them from their enemies. It is an attractive theory. It answers ten thousand riddles of colour and pattern that otherwise baffle us. I believe there must be in Nature some such design, but I find myself doubting its application in many cases where others seem to have never a doubt. Is not the theory in danger of being done to death?

In autumn a little grey-brown moth called the mottled-umber appears, and can often be seen far into the winter. Mr. Porritt, who has studied many Eng= lish moths, puts mottled-umber (Hybernia defoliaria) on a list of Yorkshire insects tending to become darker in their wing markings. His notes on what is known as melanism show a zeal for truth in little through which we may, in the far-off end, discover truth in great. He too has his doubts about mark and colour protection in insects. But whereas mine relate chiefly to butterflies, his relate to moths. 
Who are the enemies against which Nature is always protecting these moths and butterflies in their winged state $^{1}$ with the shield of colour invisibility? When we look closely we may see the armour, but not the enemy. The pepper and salt moth in the north of England has darkened and darkened within the memory of man, till now the dark form prevails; whereas in the south it has still as much salt as pepper on the wings. The idea is that this moth has blackened, in a country of black tree trunks and palings, to match its environment, and cheat its foes. But there are like cases of melanism in the Shetland Islands and in the extreme south of England. Besides, who are the deadly enemies of the moths in their winged state? Mr. Porritt cannot discover them, and I have been in the same difficulty for years. The protection idea is beautiful. I wish I could accept it wholly. It is order. Doubt it, and we seem to invite back disorder. But unless we doubt in these things, I think we cannot reach the truth.

I must be assured, first, that a creature which puts on the ingenious armour of colour mimicry needs it; second, that the armour tends to save that creature from its foes. Mere matching of bird, beast, or insect to its environment leaves me a doubter. Even when the creature appears to alter to suit altered environment, as with this pepper and salt moth, I doubt.

1 Caterpillars, I think, must often have protection through colour and form; but here I am speaking only of the winged insect. 


\section{LIFE AND SPORT IN HAMPSHIRE}

Years ago I caught butterflies and moths instead of watching them, and glancing through an old collection I find three specimens of a fixed variety of the beautiful silver-washed fritillary butterfly. Here is a case of melanism or melachroism, though no one could see mimicry in it or natural selection. The femalenever the male-has darkened into a permanent form. She has completely cast off the brown dress on the upper sides of the wings. Her spots and the edgings of her wings are darker, more emphasised than in the ordinary female silver-washed fritillary, and over the upper sides of her wings is a blue tinge or bloom which I can see distinctly when I look at her at certain angles in a good light. This boldly marked, beautiful insect, who now seems to have set aside for ever the ordinary dress of her sex, is named Valezina. I should add that, though on the whole she has darkened, she has lightened distinctly in the ground colour of her upper wings, which is creamy-cream just beginning to turn-or even white, and that the bluish tinge has taken the place of olive. So Valezina is blonde and brunette. It is melanism and albinism both with her.

I have not seen Valezina for years, but probably she still appears in great silver-washed fritillary seasons, no rarer, no commoner than she was. Fresh from chrysalid, opening and closing her wings on the bramble blossoms, she is one of the loveliest of butterflies. Losing her, the butterflies would lose a variation 
of curious interest and beauty. But how was Valezina born, and how does she survive lean butterfly years?

The case of the wren's nest is one I have often touched on. Many wrens' nests do assimilate to a fine shade, to a nicety in material, with their surroundings; but to what extent (if any) the matching of nest and site is essential to the well-being of wrens, whether or not it is the result of the law in Nature that cherishes the fittest, this is another matter. We need be shown that it is essential to the welfare of wrens that their nests should exactly match the matter that surrounds them, before we can feel sure that the wren's nest illustrates the working of the law. It is the same, I think, with the painted lady, a swift and wary butterfly that flies along many English roads and fields in late summer. In September, a few years ago, we had many in the wood. Now the painted lady is a suddenly disappearing butterfly. She settles on the road or path, shuts her pale orange-red and black mottled wings, and turns to an invisible painted lady. A friend told me that during a walk on the downs, a summer or two since, he had seen butterflies, which from his description I knew must be painted ladies, disappear thus. The instant the painted lady is settled on the ground and has shut her wings she is often quite obscure; one moment a gay, swift, alert butterfly-the next nothing.

She becomes invisible- save to the trained and knowing eye-not because her markings on the under 


\section{LIFE AND SPORT IN HAMPSHIRE}

sides of the wings are in detail like, the ground she has settled on: these under sides are marked and veined with grey and yellowish-brown, and there are tiny "eyes" at the edges of the hind wings made up of concentric rings of black, yellow, red, and bluewhich I cannot think were developed for protection; they mimic nothing on the ground where the butterfly sits. Nevertheless, the effect of the whole is invisibility ; there is a sudden, baffling change from lively flight to perfect stillness, from rather gay upper sides of wings to the chastened tinting of the under sides of hind wings-for the rosy stain on the under side of the front wings is not seen, as the painted lady draws these back. It is the same with grayling butterfly in the fir woods-another disappearing butterfly.

These things point, I may be told, to a plan of protection; I rather feel they do, though, if so, it is achieved with painted lady and grayling, not by mimicry, but by unexpected swift exchange of gay dress for grave, and, at the same moment, of flight for stillness. But here is a difficulty: why is it essential that the painted lady should suddenly become invisible? Where is the foe against whom Nature need arm her in complete mail of invisibility? I have never caught sight of him: but assume his existence and a fresh difficulty seems to arise-would he be cheated as easily as our great, slow selves?

A grassy, heathery clearing in the birch woods is a playground of butterflies in August. A few battered 
meadow-brown butterflies, their poor wings worn as jagged as those of the comma, linger on, but their junketings are nearly over. The ringlet and the large heath butterflies succeeded them before the end of the month, and occupy the bramble bushes by day and night. One year, though I watched closely in their woodland haunts in another district, among hazel, oak, and brake fern, I could find very few large heath butterflies settled for the night. But I found many on the bramble bushes in the birch wood. Like meadow-brown, grayling, and other butterflies, the large heath, settling for the evening and night, always draws down its folded upper wings, so that the conspicuous spot or "eye" on the back of them is hid. One effect of this is to make the large heath a trifle obscurer at rest on the bramble leaf than it would be with the wing up. But somehow I cannot believe the real explanation of this withdrawal of the "eye" from view is protection of the butterfly from enemies of prey by inconspicuity, or by assimilation to surroundings (gross words to use of a sylph like this butterfly! but I know not how to avoid them). My notion is that there is no night enemy that need be cheated-if it could be cheated-thus. Protection of butterfly beauty against weather is, I think, the meaning of the withdrawn "eye." If you set out to look for butterflies at rest matching their environment, no doubt you shall find them. The small skipper butterfly sleeping on the spear thistle looked greeny-grey, I noticed, 


\section{LIFE AND SPORT IN HAMPSHIRE}

matching his perch. We watched a meadow-brown, disturbed by large rain-drops, perch on a birch twig, and put away his "eye," and we agreed he might pass for a dead leaf. But other small skippers, small and large kinds, slept on seeding grass heads, and the matching was not close; and, after all, is the meadowbrown so very like a dead birch leaf when you come to think of it?

More striking was the case of the golden Y moth, the pretty insect which I have found in moist places in the Surrey birch woods, and which flies often by day. I watched one settle on the trunk of a birch tree. It has some dark fluff or fur, standing out like a hump on the back, which reminds me of the dark, rough cork of the birch trunk near the ground. If this were the usual resting-place of golden $Y$, it would seem very like a matching precaution; but I have no proof that golden $\mathrm{Y}$ moths prefer for sleeping quarters the rough, corky trunk of the birches; I think my moth settled thereon by chance. I found him first amid the copse grasses and cross-leaved heather, and I found another golden $\mathrm{Y}$ moth next day resting off the birch trunk in the under cover of the wood.

In the lane end of the birch wood I have seen the silver studded blue butterflies sucking the bird's-foot trefoil and the bramble blossoms. The silver studded, with lilac-blue wings and their clear fringe of white, is quite as lovely as the common blue butterfly; indeed, in minutiæ (and perhaps because he is not so common) 
I think him the choicer of the two. Of the sleeping quarters and habits of this gay beauty I know little; one or two I found at rest slept head upward, not like the common blue, their near relative, head downward; but perhaps this was exceptional, due to some chance disturbance: I can hardly imagine the sleeping habits of the common blue differ from those of his first cousin.

Nobody could doubt that to watch butterflies and moths is to train the eye to beauty on a scale of exquisite, if tiny, perfection; this is absolutely plain to every seeing, thinking man. But a study of the habits, minutiæ of minutiæ, of such little thingshow, it may be asked, can this avail human beings? Is not the man who does it rather like Browning's grammarian? Would it not be wiser to aim at the million and chance missing the unit? Yes, but in these units secrets of life, secrets of Whence, Whither, Why, are concentrated. In the end we may know ourselves through a blue butterfly as through any of the more "majestic pieces" of Nature. Only we must watch and record, independent of any theory, seeking only truth. 


\section{CHAPTER IX}

\section{INSECT LIFE (Continued)}

THERE is a spot on the railway bank facing south-east which I cannot pass on hard winter days without recalling the rich June scene of butterflies and moths. I think of its little Bedford blue butterflies, and swiftflitting skippers, and the wood tiger moth, that seems to fly at random among the grasses and flowers, yet will return day after day to the same patch of ground. The difference between this place in June and in January is incalculable. In January, its thin cover searched through and through by the east wind, it is exposed, colourless, uninviting; by June a garden of honey.

But June sleeps in January. The whole wealth of the summer, when this bank will be a paradise, is actually stored here now. The place need not draw its flower, grass, and insect population from fields and woods around. It is self-contained. The flowers and butterflies and day-flying moths-heath moth, orange underwing (brephos), wood tiger, six spot burnet-are scattered over this bit of chilly ground, which, like the marsh in mid-winter, looks as if it could never live again. They sleep obscure, epitomised in tiny 


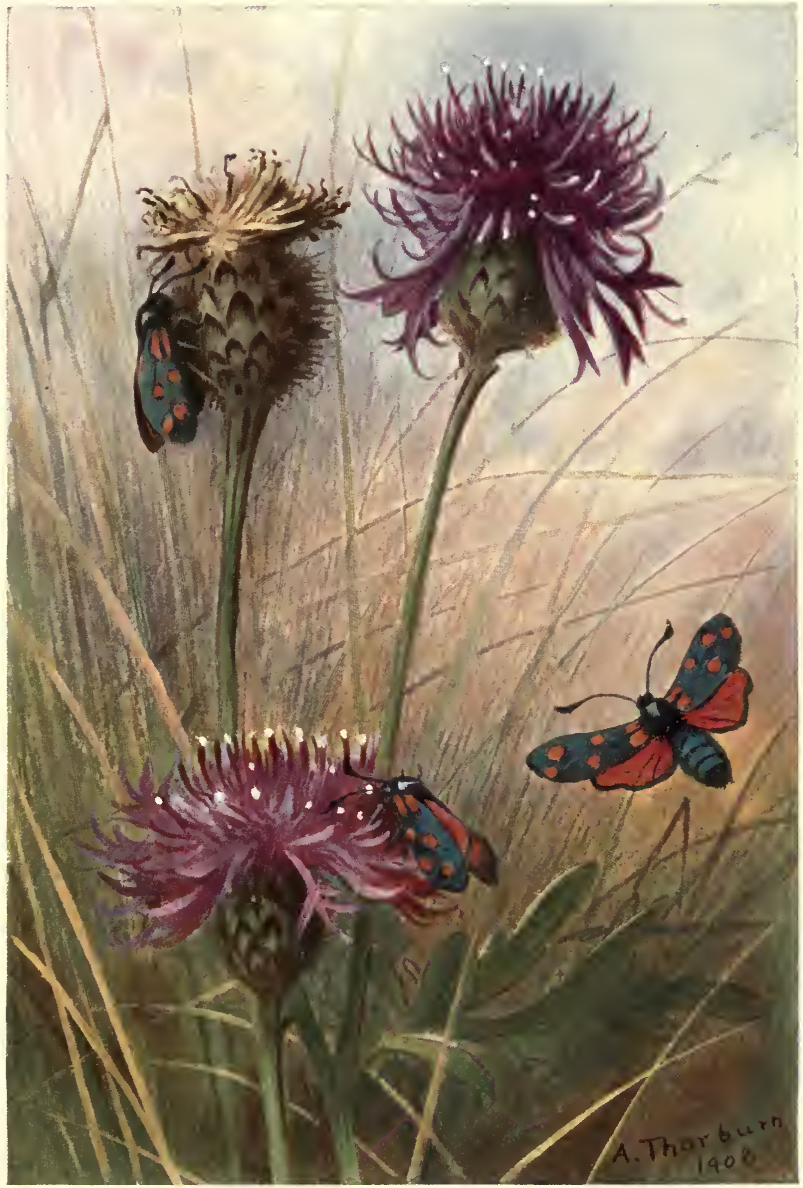

SIX-SPOT BURNET AND GREATER KNAPWEED.

From a Water Colour Drawing by Archibald Thorburn. 

egg, seed, or chrysalid. This compression of life is as curious to consider as the sleep of life in winter. Such a trifle of matter serves as a receptacle for the divine spark.

There is one spot, about midway up the slope, where the larger knapweed grows, and here in later summer I have seerr the six spot burnet moths settling for rest as the afternoon begins to grow cool, for the burnet is a moth of the day. The burnet moths are here in January obscure in the frozen slope, the bronze and red and the high polish of their wings and bodies, for they belong to a great branch of Nature which is ever being shrivelled up into all but nothing, and ever re-created into fresh and brilliant life; is not a moth egg or a moth chrysalid, or the seed of an annual wild flower next to nothing in our eyes? It is the same with knapweed, which is also scattered obscurely over this bare slope, waiting for the full, hot breath of summer. The burnet moths spend summer nights on knapweed. On this slope I have noticed that the knapweed is reserved for the burnet. This highcoloured insect sleeps on the high-coloured flower. Is this a bit of evidence for the theory of colour protection-the moth matching the flower, so that keen-eyed enemies may not find and snatch it? Finding two or three burnets clinging to the green prickly knob under the blossom, I thought it might be a little evidence. There is green about the burnet moth's dress that might be said to match the knob of 


\section{LIFE AND SPORT IN HAMPSHIRE}

the knapweed. But when we come to examine many knapweed blossoms, the theory for colour protection vanishes from thought, for, mostly, the moth fastens itself for the evening and night not on the green knob, but on the purple blossom above; and there is no matching of colours here. The high colour of the flower does in some degree kill the high colour of the moth; the burnet is not so noticeable on the knapweed as it would be on the ox-eye daisy near by; but there is nothing like mimicry or assimilation. What makes the burnet, then, on this slope fasten itself always to the knapweed, sometimes to the knob, but more often to the blossom itself? I fancy the cause may be comfort. The burnet is a heavy insect, which, sleeping on such a perch as a blue butterfly chooses, might be swung and battered to the ground by a breeze. The ground must mean death to insects, for it is here that night foes lurk and crawl-the mouse and the toad, and many another. Besides, on the ground, with the weather wet, they will be drenched and perhaps overcome. I say this mindful that some moths rest on the ground, low down among grasses and leaves-yellow underwing moths, for instance. But these exceptions do not persuade me that the safe seat for a moth or butterfly at night is not aloft.

Another instance of the natural selection which has preserved the wild creature is seen clearly by some eyes and minds in the seeming pretence of 
death by insects-and even some birds-in danger. It is illustrated in a droll way by caterpillars. In a field at the back of my garden are some beds of nettles which have rooted themselves very firmly. Now and then a man is sent to attack them. He digs at their roots for an hour or two and seems to have made a good job of it. Only seems, for really the wicked nettle-what a coarse, spiteful thing it looks, leaves, stem, and all!-thrives through the very hand that would kill it. The digging only divides roots and stirs the soil to feed the nettle better. Hence the beds of nettles grow larger. On one bed a large community of peacock butterfly caterpillars were settled in July. Proof against stings, they spin ragged webs round flowers and leaf, and feed up. Tap the nettle head smartly with a stick and a little shower of caterpillars pelt on the leaves beneath. They relax hold of the leaf or flower, and let themselves fall. Some reach the ground, but a large platform leaf will catch and hold a couple of dozen. There is a little stir and writhing, and then dead stillness.

Two dozen tiny black caterpillars, from a quarter to half an inch long, seem to lie stark dead on the nettle leaf. An odd thing is the variety of attitude in which they die. There is no sudden death on the stage done so well as this. One little black caterpillar lies stretched flat at full length, a second is curled up, a third's on its back, a fourth's on its feet; 


\section{LIFE AND SPORT IN HAMPSHIRE}

fifth, sixth, seventh, eighth, ninth, and tenth are twisted and writhed in comic fashion, heads or their tail ends stuck into the air; whilst at one spot on the nettle leaf is a little jumble of black caterpillars, a dozen or so lying anyhow. They one and all look exactly like dried-up, jejune caterpillars, mere shucks or skins, not worth a bird's notice.

I watched the two dozen dead caterpillars for a minute or two. Not one stirred. Their positions looked so uncomfortable that, humanising them in thought, I half expected to see one or two of them stealthily move; as if a man shamming death, and finding his arm or leg getting the cramp or his neck or back beginning to ache intolerably, would try quietly to slide into a kinder position. But no such weakness affects the peacock caterpillars. It is as though they knew-or Nature knew for them-that their life depended on dead stillness. Probably there is not the slightest discomfort for a caterpillar in these awkward, uncouth attitudes. Anyhow, there they remained; and not till I returned several minutes later, were the ugly little black things straightening themselves out and examining new leaf quarters. Tap the nettle again, instantly every caterpillar drops dead again, and is dead for several minutes. That this sudden fall and the stillness which follows are useful I quite think, though once an enemy visits the nettle bed, it will on doubt seize a certain number of caterpillars. 
When you see this droll thing, and look down on the caterpillar corpses, it is hard not to believe that, one and all, they are shamming death, so that an enemy may not eat them up; for, you may argue, a dead caterpillar is not likely to suit the nice taste of a bird. The caterpillar corpses out of sight, and only thought about, you are more likely to conclude that the thing is out of the question-that a creature intellectually so mean as a baby caterpillar cannot sham anything. What brain could there imaginably be for craft in that ugly black-pin head of the peacock butterfly grub in its babyhood? Death is a thing of whose nature human beings, probably alone among living creatures, have the smallest inkling. The most, then, we can imagine the baby caterpillars doing is keeping quite still to escape the attention of some enemy which might seize and eat them. Even this act of shamming, we argue, further, is not their own. It is Nature's deception, not theirs. No glimmering of intelligence taught them to strike these queer dead-and-dry attitudes. Rather, we think, it has come about thus: those baby caterpillars that originally tended to fall off a leaf at the least disturbance, and remain still the longest, tended to outlive their less fortunate-not less intelligent-fellows; and so the tendency became set and hereditary. Those baby caterpillars that did not fall off at the least shock and shrivel up into stillness-they or their descendants, were gradu- 


\section{LIFE AND SPORT IN HAMPSHIRE}

ally eaten up till in the end, only the dead-and-dry variation survived.

Assume, then, that this habit in the baby caterpillars of the peacock butterfly of dropping off their leaf, and of lying stock still in seeming death, is a protection to them in danger; that it has become a fixed habit, and is perfectly automatic-no more an effort of reason than is the eating of a nettle leaf and seed or the transformation of caterpillar to chrysalid, chrysalid to butterfly. Here arises another question; why, as the baby caterpillar of the peacock butterfly falls off its leaf and lies stock-still for whole minutes in odd attitudes, does not the grown-up caterpillar do likewise? The full-grown caterpillar of this butterfly does not fall down and sham dead when the nettle is tapped, or itself touched with twig or finger. Several times I have assaulted the large, full-grown caterpillars of the peacock butterfly-but they will not perform as they did in their babyhood. They do not tumble down, unless quite rudely shaken; and they do not, when down, twist or double up and strike fantastic attitudes, suggesting deadness and dryness. Indeed, though they may cringe or writhe a little when touched, they are not much concerned, and will go on nibbling at the edge of their nettle-leaf. This is a little embarrassing, if we have been hugging fondly the belief that the habit of falling and of shamming dead was protective in the baby caterpillars. If the baby protects itself-or natural law 
protects it-thus, why not the adult? I am not much embarrassed myself, because I have not hugged the protective theory in all these matters very fondly. Say, however, one does believe absolutely in the protective theory here; then I suggest this as a possible way round the difficulty raised by the stolid behaviour of the full-grown caterpillar. 'The caterpillar is now almost two inches in length, and armed all over with black spines or bristles. It is said the cuckoo is one of the few English insect-eating birds that will tackle large bristly caterpillars. So, perhaps, the peacock caterpillar, when full grown, is no longer in danger of being eaten by enemies; and, therefore, it need not hastily tumble off its leaf and die. No doubt it needs a somewhat lively imagination to agree to this change in caterpillar habit; but how otherwise may one account for the fact that the baby shams death for protective purposes, whilst the adult does not?

The peacock butterfly caterpillar at this spiney state of life is much better-looking than it promised to be in babyhood. Besides its bristles, it has neat, regular lines of white spots, somewhat like tiny silver sequins sewn on some velvet material of a lady's evening dress, and its legs are reddish. The decoration of a caterpillar - and the way in which with some kinds of caterpillars this decoration varies according to the age of the grub-is a most recondite matter. There is no courtship or rivalry for a caterpillar. The sexual motive does not come in. Yet it is impossible 
to suppose that all the finery of caterpillars means and leads to absolutely nothing. Hence, some minds have concluded that all the fine colour and patterns on a caterpillar's skin are nothing more or less than warnings to its enemy that it is not fit for food. If this were so, the peacock butterfly caterpillar, full grown, would be armed indeed against the foe; the silvery sequins on black velvet would warn the foe; and, if these were not enough, the spines might well repel it.

Often intelligence in the insect world seems but automatic intelligence, working in machine-like fashion, so that seeming exceptions may be almost startling. I recall one which I noticed whilst angling. There is a grasshopper, whose name I am not sure of, very lively in a reed bed by the lower Test, where I have seen the lovely scarlet tiger moth flying, like a butterfly, in full daylight. A patch of reeds will be loud with these insects on a July day; they jerk about amongst the undergrowth, preferring spots for song and exercise where the reeds are thin, and louse-wort and other marsh-loving plants thrive. Alarmed, they take a flying leap or two, but will soon give up this plan or instinct of escape. Instead, the grasshopper will jerk itself on to the stem of reed or river grass, and, in this position, clearly keep an eye on you, if you go near and attend to it. Here is nothing out of the common insect run. The automaton is working in the familiar way; no sign here of insect thinker or scheme. 
I might have left my grasshopper on the reed stem, expecting nothing new from it; but, wishing to note its colour and markings, and get an accurate notion of its size-it is short-horned, about an inch or rather more in length, and brighter than the commonest of our grasshoppers, Gomphocerus maculatus - I walked round the stem to observe from all points. Now happened a thing, to me, extraordinary and ludicrous: as I moved round the stem the grasshopper slid round too. So round and round we slowly went. The grasshopper would not have its back to me. It moved slower than I did, but, if I stopped moving, when I was looking at the back of the grasshopper it always would work round till it faced me. The tortoise would, in the end, be equal with the hare. Possibly I might have over-walked, tired out, the grasshopper, had I kept encircling it; but, feeling sure the movements hung on my movements, that it was intent to face me, I came to a standstill, and plucked the reed; a moment or two later the grasshopper jerked itself away into the undergrowth. I do not imagine this odd performance was peculiar to my grasshopper. Here was no genius or insect thinker, one grasshopper in a myriad. It must be a habit of this species, perhaps of various species, of grasshopper and locust, though I have never noticed it in one or two other kinds I have watched in fields and hedge-banks.

But even so the thing is very curious. What 


\section{LIFE AND SPORT IN HAMPSHIRE}

draws the grasshopper round and round the reed stem, and brings it to a full stop only when it faces the intruder on its haunts? Can it be anything but a precaution, a wish to face the possible enemy, and so be readier to fly, should danger threaten? I can think of no other motive; and whilst actually watching the action of the creature, I cannot doubt that this is the explanation. Many insects can see behind as well as in front, but I suppose my grasshopper's vision backwards is not so strong as forwards. It may be argued that even this habit is automatic, quite unconscious, no sign of understanding in the grasshopper; that those grasshoppers which tended to move round their stems, and so to face possible foes, tended to survive in the fight of life; and thus the habit, highly useful to them, though it sprang from "chance," became fixed. An ingenious solution, but such solutions sometimes leave one cold and doubting. The pity is-or is it the mercy?-that the real origins of all such insect habits and intelligences are utterly prehistoric. The Old Stone Man, whose flaked flints we find deep in the gravel drift, close to these grasshoppers, belongs to a past not more difficult. We may rebuild the plesiosaurus in outline, but not the stages by which the honey-bee came to be air-fanner and cell-sealer, or by which my grasshopper learnt the value of facing its foe.

There is no familiarising of the honey-bee. I 
never take the quilt off those glistening combs without a slight feeling of awe: it is as if one were opening the door of a chamber of mystery, stepping across the threshold into a place unknown, darkly wonderful. But the mysteries of the bee do not blind us to the plain fact that her intelligence runs in grooves; is of a strictly limited character. By the side of the overcrowded hive, out of which the old queen emerges, with her great following, is often an empty hive, admirably suited to the new monarchy -or republic, for, despite tradition, it more nearly resembles the latter. Often, before the swarm comes forth, this vacant hive has been critically examined by many bees, apparently explorers. Yet how seldom is it chosen and occupied without the guidance of the bee-master! Instead of going into this hive, ranged and ready for them, the swarm will gather in a cluster on a tree or bush, finally to settle, if they are not taken charge of, in the roof of a house or the hollow of a tree. But only introduce them to the beehive which, in vain, their explorers have examined, and which they themselves have passed a hundred times a day, and they will joyously run up the alighting board, jostle in at the entrance, and take possession of the very spot that they need for founding their State in.

If their intelligence has anything like affinity with human reasoning power, surely the swarm, on emerging with their queen, would go straight into that empty 
hive with its hanging row of bar-frames, each supporting a sheet of wax, ready to work out into cells. Instead, the bees will waste a precious day or more at the height of the honey flow, examining, reexamining, some crevices about a wall or roof, which are not the least good to them. It is mentioned as a sign of the bee's wisdom that the swarm coming forth will often fly several miles away from their old home-as proof that the bee does not wish to overcrowd his neighbour. But if so, why, when the swarm is shaken down in the cool of the evening on a white sheet outside the empty hive, do the bees promptly crowd up, with all the music of satisfaction, carrying their queen with them, and take possession?

No, the bee intelligence is strictly limited. What we term reasoning power does not seem to exist among bees. The arrangement, the order of their State, is beautiful. T'he spirit of the hive is beyond praise in its devotion, endurance, fiery patriotism. But here end the virtues of the bee. Compared with those qualities her intellect is beneath contempt. Her machinery of mind cannot move outside the deep worn grooves of habit, which I suppose were slowly made, geologically slow, in the unreckoned thousands of years of her unknown history-for this must be one of the most ancient civilisations in the world.

Watching beasts, birds, and insects, one is struck by the dead level of their intelligence, by its diffusion 
among the entire species, by the grooves in which it runs. Once take the wild creature out of one of these deep grooves, face it with novel conditions or difficulties, and its understanding and resources seem to fail.

Bees set in a country unknown to them will soon find their way to the best honey fields miles around. All bees, in health and strength, seem to be equally good in this; leaving the hive on the very morning it is set in a land new to them, they will range far and wide at once, and yet find their way home. But move the hive a dozen yards, or less, whilst the workers are foraging, and when they return they will be utterly confused-they are out of the groove. There is the hive a few paces off, clear as can be; yet with all the thousand facets of her wondrous eye, the poor bee is lost and confounded. She will settle on the spot where the hive was, and crawl about there; it may be she will never enter the hive again.

All the wisdom and patriotism of the hive runs in grooves; all the precautions against weather, disease, enemies. As to the last, Huber did make an astonishing statement. He described the death's-head moth as a new enemy of honey-bees in his part of France, an insect which terrified them and entered their hives after dusk. He said that he took measures to prevent the great moth entering the hives, but found that many of the bee communities had taken their own precautions, building a waxen wall to keep out the 


\section{LIFE AND SPORT IN HAMPSHIRE}

intruder. One or two writers after Huber described quite a complicated plan of fortifications made by the bees against the moth, and commended this ingenuity to the Vaubans of the age! Huber surely was misled by some wrong observations by his assistants. Nothing in the wonderful life of the honeybee promises sudden originality like this. Put the bees in difficulties they have not almost daily to overcome, they are helpless.

What is it determines the rôle of the working bee - whether it shall be gatherer of pollen, gatherer of honey, garnisher of the hive, constable at the entrance, air-fanner? It is when we ask ourselves a question like this that we must feel we are yet scarcely on the threshold of knowledge as to the life of the honey-bee. There is nothing to show that guards are stationed at the entrance; that fanners are told off to agitate the air within the hive. This would imply a superior officer, a monitor, or ruler, and there is no semblance of such authority in the hive. There is what we call a bee-queen. But she attends to no such matters: she issues no orders. Really, she is not a queen despotic or constitutional. She is the great mother bee.

So far as we can peer into the life of the hive, we find not the least sign of orders given; nor have we evidence that one bee is born a collector of honey or pollen, another a guard, a third an air-fanner. The bee that guards to-day may gather to-morrow; 
she may be attending to the atmosphere of the hive one hour, sealing and securing the hive with propolis - bee cement-next day.

Yet apparently there is always something that in practice is as effective as a regular division and distribution of labour. With a strong and healthy hive, there is no danger of any of the various bee duties and necessities being neglected. No orders are giventhere is no ruler to give them; and yet, unless some disaster through sickness or deadly enemy comes upon the hive, here we see efficiency in every department of the State.

I have denied the queenship or supreme authority of the queen bee. There is, however, one way in which she does exercise something in the nature of leadership, acting perhaps on her own initiative. This is when the moment comes for her to leave the hive peopled by her own daughter-workers and son-drones in thousands, and establish a new colony. Here, it seems, the profoundly important decision as to day and hour of going rest with her. There is tumult, seething excitement sometimes, among her children, before the event; but does not the hive, or that portion of the hive which is to leave its safe home and stores, wait upon her will? The movement and restlessness of the bees may affect, urge her on, but nothing can be done until she leads forth.

The full and exact story of the drones has, I believe, yet to be told. Their expulsion from the hive 
is one of severity and force; but, so far as I have witnessed the scene, they are not executed. Possibly the drones which I have seen hustled and expelled from the apiary in the woods were treated more gently than drones are as a rule. Certainly many beemasters have seen drones killed by the workers. But my impression is, the drones' lives are not usually taken by the worker guards or police, whose business it is to clear the hive of them in late summer or early autumn. In some years large numbers of expelled drones fly in at the west windows of the house, and linger about the curtains and glass till far into the autumn. This does not look like wholesale execution. One spring I found a solitary drone which had survived the winter, and late in the year a fire in the bedroom roused another hibernating drone, which was still bright, lively, and in fine condition. These instances prove that the drone, unlike the worker bee, can live for many months quite alone, and without food. They show, too, that a drone is not chilled to death so easily as the worker bees, which live during winter in a temperature that sometimes reaches over ninety degrees at the bee cluster in the hive. It has occurred to me that a drone can live, or half-live, in conditions which would be fatal to a worker bee, because through luxurious fare and a life of leisure he has built up much more strength and tissue. $\mathrm{He}$ is too strong to be killed by the first touch of cold autumn weather; and 
thanks to the golden combs into which he has generously dipped during the summer, he can exist without food for some time after the expulsion. But that this numbed half-life is utterly worthless seems clear. The poor drone, pampered darling of the hive so long as there was the least chance his services might be needed, after the expulsion stands for all that is superfluous. $\mathrm{He}$ winters utterly in vain.

Most insects that in winged form survive the English winter are proof against the longest and sharpest spells of frost. The harder the frost, the deeper the sleep of brimstone and tortoise-shell butterflies; but not less sure their awakening in March. But the hive bee-or, say, the honey-bee, as these are wild bees, whose state in winter is identical with that of the apiary-is an exception. It is very susceptible to cold; a short exposure to wind and wet in January kills it. The cold has, up to a point, the same effect on bee as on butterfly-it numbs to sleep. I have never experimented, but from observation should say that butterfly is numbed quite as soon as bee. Bees are on the wing-homing from distant fields of honey - when every butterfly is asleep. Yet, though so soon numbed by cold and wet, the butterfly, in a state of coma, can live through several days, possibly weeks, of unkind summer weather; whilst a few kinds of butterflies, in a deeper coma, can survive the hardest winter. The bee, 
which looks robuster than the butterfly, is chilled to death by exposure to a few hours of moderate cold. It is common to find shrivelled dead bees on the combs of the hive in winter. They have been chilled or starved to death within a few inches of plenty and warmth, for between the next two combs, at the centre of the hive, are not their fellows basking in heat and honey?

What is the heat of the hive at this cluster of bees by the centre? A temperature of $90^{\circ}$ is often mentioned, and, putting my hand immediately over the cluster beneath the felt one day, I was struck by the warmth of the air. If a thermometer could be put in the midst of the cluster, and kept there a while, it would register a higher temperature than if laid between the top of the combs just above. A bee-master of long experience gave me some figures, about the heat of his hives in autumn and winter. The stronger the stock the higher will the temperature tend to be; a very weak stock, I imagine, would not be able to keep up enough heat for life in a severe winter. The highest temperatures of a strong stock recorded by my friend are:-October 1905, 7 P.M., $83.5^{\circ}$; November, 7 P.M., $83^{\circ}$; December, 7 P.M., $74^{\circ}$; January $1906,8.45$ P.M., $86^{\circ}$. He says that, no matter what the thermometer outside may register, the night temperature at the cluster is from $3^{\circ}$ to $10^{\circ}$ higher than that of the day. The lowest temperature he has recorded was at 8 A.M.; 
whilst twelve midnight seems the highest, but it has seldom been taken then.

Clearly, to keep awake the bees need a high temperature, and sleep or coma, unless speedily arrested, for the worker bee means death. I have shown that this is not always so with the drone, for, expelled the hive, he does sometimes live through the winter like a brimstone butterfly. My friend has never known drones to live through the winter, but this occurs now and then in hives which have lost their queen. At first thought this may seem like a wise provision. Are the bees keeping their drones so that they may requeen the hive next season? or have they taken steps to get a new queen at once by nursing ordinary worker eggs - of not more than three days old-on royal jelly, and building a special cell about these treasures? But drones suffered to live on in the hive through autumn and winter are not proof of such wisdom in the bees. They are useless, worse than useless, for by dipping into the honey stores they may merely serve to shorten the life of the hive. It is because the worker bees are demoralised by the loss of their queen that the drones are spared. The glorious machinery of the beehive has broken down. It is as if the bees lost heart and head. The workers may struggle on to the last (as I have seen them do when the terrible wax moth has overcome them utterly), some even laying eggs as if they were queens-eggs that, by one of Nature's startling ironies, produce nothing but drones ! 


\section{LIFE AND SPORT IN HAMPSHIRE}

But, in a few months at most, unless man comes to their aid and gives them a new queen, the stock must perish.

That is the slow ruin of the hive. But sometimes when the stock is weak the hive will be destroyed in a day. I have watched the storm and sack of a society of bees. This is all desperate heroism and bravo, a piece of Nature's melodrama, with a scene at the close full of strange pathos. A mere battle of bees is of no special moment. It is quite common. At the end of summer, when the plants yield no more honey, bees will often turn robbers, and try to carry off the stores of neighbour hives; for the honey-bee has no morality outside its hive, its ethics beginning and ending at home. But a fierce, prolonged onslaught by a great body of bees upon another hive, ending in the annihilation of the defenders, is another and rarer event.

In this case, after two or three skirmishes or reconnaissances, the robbers came in a large and resolute body. Their numbers were quickly swelled by many hundreds of eager wasps, and after a savage fight, lasting nearly all day, the hive was carried by storm, and its population, as an organised society, had ceased to be.

At sundown, when the uproar had almost ended, I was able to examine the field of battle, and find out what had been done. By this time most of the invader bees had left the ruined hive, laden on many journeys with the spoil. The field was held by the wasps, still ravening for prey. The ground around the hive was sprinkled with maimed and perishing bees, 


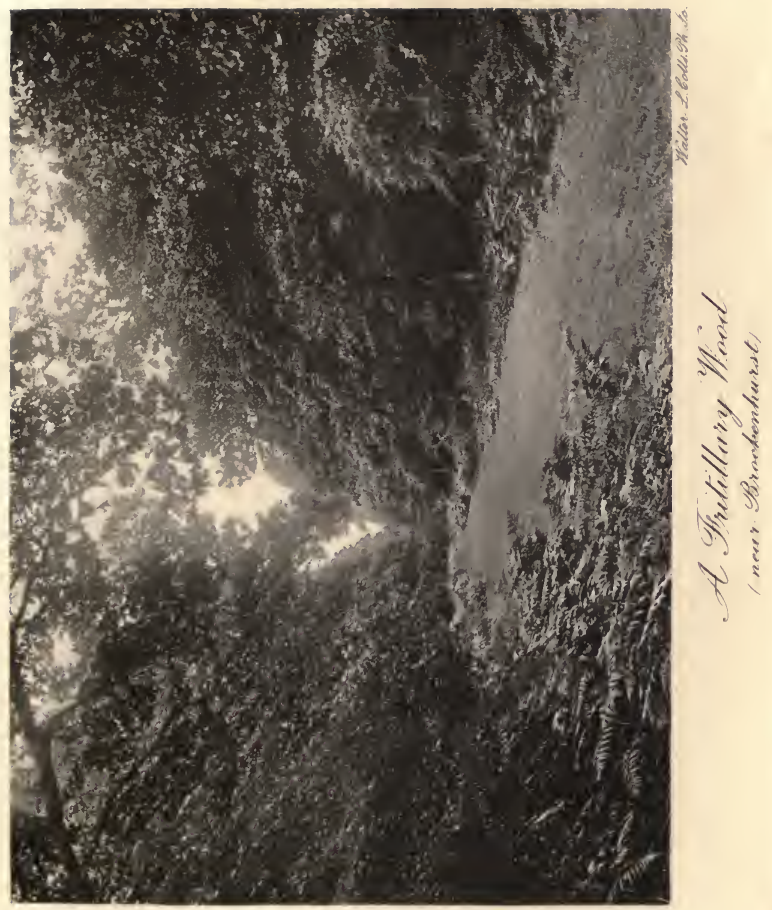



crawling miserably about, and trying vainly to use their wings. Other bees, in a coma or dying state, were clinging to the sides of the hive or the alighting board, or to grass stems, and were being milked of their honey by the wasps. I saw two, even three, wasps holding one bee, greedily competing for the contents of the honey sac. To judge by the clean sweep made of the conquered, many bees must have been cut in two and carried off to a wasp nest near by. But I did not actually see this done; the wasps attending to bees outside the hive on the evening immediately after the fight were, I think, only drawing the honey from them.

The victims, finding their hive stormed and the guards overcome, had rushed to the cells and filled themselves with honey, much as people whose house is on fire will try to collect their valuables ere they fly. This is the habit of alarmed bees. Tap their home smartly with a stick or the flat of the hand, or send a puff of smoke into the combs, and the bees, with a loud, instant roar of excitement, will rush to the honey stores and fill their sacs. Perhaps they expect to be driven from their home, and so must fill themselves with provender against hungry, homeless days to come.

I took off the roof of the hive. What a scene of ruin and confusion! The damage must have been done in one day, for on the previous afternoon the defenders had held their own, guarding the entrance, 


\section{LIFE AND SPORT IN HAMPSHIRE}

dashing to the ground wasps and other bees which came singly or in parties. I found all the combs gutted. Fragments of wax were strewn about. Most of the cells had been opened and sucked dry. The grubs, torn from their cradles, had been carried off by the wasps. The princess or queen cells were empty with the rest. And combs that a few hours before would have scaled four or five pounds apiece were light almost as if made of paper. More than two years of labour, the intense spring and summer labour of several generations of workers, had been thus spoilt. The queen had roamed from cell to cell laying in vain her tens of thousands of eggs.

I know of no tragedy in the world of winged life so appalling as the ruin of a bee society through mishap. The wasp nest always falls to ruin and death at the end of the season, winged and unwinged alike perishing miserably; but its ruin is strictly within the law of Nature; the ruin of the bee hive is without the law, an accident and a disaster. Besides not all the wasps perish. The queen will live, and she carries in marvellous microcosm the whole state or society, which she will refound in due season.

There is no asylum for a bee-worker, guard, queen, or drone-once its hive has been stormed and sacked. If it sought shelter in another hive it would be detected by the hot guards at the entrance and beaten down. It is an outcast, a pariah ; and ere night comes it will be numbed to death. 


\section{CHAPTER X}

\section{THE GREE WORLD}

Is February, wandering in these southern lanes and woods, we grow conscious with a great pleasure and refreshment of the rebirth of a green world. The Hampshire woods and downs and open fields look as wintry in February as they looked in December, if we take whole landscapes. There are patches of snow perhaps in the shade; but it is another thing when we look close into the banked hedgerows facing south and south-west. Here the quickening of the earth is clear enough, through various small green things; it is delightful to take the inventory of the thorn-hedge late in February. The faint green moschatel in the innermost recesses of the clipped thorn hedge has thrust up an inch. It grows through the sandy scrapings which each winter are shovelled off the road on to the bank. Once we know this charming plantlet, so modest, hardy, early, obscure, we look for it year after year. It is a precise little thing; has a well-defined season; it always comes by March; is always done in May. Here is not one of those spring plants which will flower in autumn and winter, such as primrose and violet. When moschatel breaks 


\section{LIFE AND SPORT IN HAMPSHIRE}

through the soil, it looks, as do the dog's mercury and some of the chervils and ferns at the same stage, rather tousled. At first glance, its tender leaves might appear scorched by frost-the mark left by frost is often like the mark left by fire-and drooping from the punishment. But, looking closer, we find that the tender green has not been burnt by frost or bruised through forcing its way through the soil; it is only that the wizened little leaves are uncrinkling.

Then, with lowly moschatel, but far more widely spread, unfastidious in choice of growing place, the common chervil or cow parsley is also adding to its greenery in the February hedge. Here is a perennial, which grows green leaves, beautiful leaves, all the winter, unlike some of its cousin chervils, which are perennial, too, but in winter live only in their root, hibernating in the dark. Chervil puts out fresh, ferny leaves in February, which, like the moschatel's, pushing up through flinty road scrapings, wear the same bruised look.

The manner in which these tenderest of tender leaves force their way to light, lift and push away the hard, caked soil, is a constant wonder to me. Pick a young leaf of chervil, and with it try to break through a piece of caked earth half an inch thick-you might as well try to force it through a sheet of iron. How then in Nature can chervil leaf lift and thrust aside the earth? I suppose it is done by gentleness and persistence together. Gently, ever so gently, the 
chervil stem, with the curled, bent-down leaves at its top, feels its way up, insinuates itself through the soil.

Moving up-could we but watch it in this travel -as imperceptibly as the sun moves across the sky; and behind this movement of the chervil a force of will, nay, a law of will, as tremendous and immutable as that which whirls the planets round their sun.

It is an object-lesson, this plant travel up to light through impediment, in the power of gentleness and will in union that perhaps has no equal. Very wonderfully it illustrates what may be done against hard things by quiet and persistent endeavour. Will in human relations we incline to think of as something the very reverse of gentle or tender; something that lives in men cut out of granite or encased by iron; but, as chervil proves, will can have its habitation in substance so frail and soft as to be bruised by the light pressure of a child's finger. So indomitable will need not live in fortress of iron or stone.

But most the chervil illustrates the virtue of gentle persistence-ceaseless, sleepless, but unnoticed persistence. It does nothing by furious spurts. The spurt means some waste of energy. Then follows reaction, a slipping back. The will of a plant is nothing if not even. It never waxes, never wanes. It has grownfor I cannot suppose that it started at this perfection - to be as sure, even, perpetual, mathematically exact 


\section{'216 LIFE AND SPORT IN HAMPSHIRE}

as the law of gravitation. Indeed, like gravitation, it is a law. The will we deal in seems to be outside law. Hence its irregularities. But this is certainthe more the will of a man resembles this will of a chervil plant in its method-quiet, and deep, and gentle persistence in the object aimed at, the surer is it of triumph.

Ours is a land of yews. Single trees, groups, here and there even a grove of yews, are scattered throughout the Hampshire chalk. The greatest of them all, I think, and perhaps the eldest, is in the churchyard at Woodcot, one of the least known spots in our Highlands. The yew is a great tree at all seasons, grandly English; but in spring it has a sort of personality about it which attracts me greatly. If a tree could be in love, I think it would be the yew in full spring dress. The smart new crest of the plovers and the high burnish of the doves in spring point to the passion of the mating season; animal and plant life can hardly be separated : would it then be so fantastic to speak of the courtship and marriage of yews? Like plover and dove, the old male yew tree in early spring passes through a beautiful change. A yew across the lane, or in the next field, seems wholly to have changed colour since mid-February. By mid-March it does not look green in some lights; at any rate, green is not its chief colour. We see yews a hundred yards away of a red or brown colour, which, on nearer inspection, alters to a flesh tint. 
Such yews are covered with blossom, and I doubt if any plants or trees in England, not even the dusty grass-heads of summer, better illustrate the splendid expenditure of Nature.

Tap the yew branch that faces south, a quick little puff of powder comes out, and is lost to view in the instant of its coming: so much plasm is spent: not that it matters in the least, for a little later in March or April every gust will spend the substance out of which the yew trees of future generations and centuries alone can be formed, and yet pollen and to spare will be left for the work. The pollen grains of the yew in full bloom would only be reckoned by the kind of figures in which the distances of star and nebula are reckoned; it is a case, like that of the gossamer spiders of autumn or the dancing columns of winter gnats, of the infinite just without our doors.

The female yew tree in March has not changed her dress for the season of tree courtship and marriage; she is just as she was at the beginning of winter after the thrushes had eaten her last red berry. Her blossom is scarcely worth the name, her green dark and severe as ever. The male tree is not only flushed with particularly delicate colour-top, sides, and even hidden inner branches which no sunshine touchesthrough the little balls of blossom; he has lengthened thousands of his twigs by several inches, in some cases by as many as six, and these he hangs in little festoons, with leaves fresher and shades lighter than the green 


\section{LIFE AND SPORT IN HAMPSHIRE}

of the old twigs. It is the new twigs that are weighted with the pollen, many being divided into several little branches bunched thick together; a single branch, two inches or so in length, will often bear a full dozen balls of blossom. It is easy, then, to understand how the whole look of a large yew at a little distance may be altered in March.

Without pollen there can be no yew fruit, no seed for keeping up the stock; and this pollen, so far as we know, depends for carriage wholly on the wind. Certain insects may be found on the pollen blossoms at times-I have noticed green flies there in Marchbut they do not fetch and carry the treasure from tree to tree. The wind is the only known porter for the yews, and how can Nature rely on this fickle agent to carry the fine yellow dust without failure from yew to yew when the trees are separated by hundreds of yards?

Billions upon billions of grains of pollen-yes, but for a single grain that is carried safe and sure from anther to pistil how many grains must fall to the ground or on surfaces where they are useless?

It would seem the merest chance in the world, a fluke, if the wind take the pollen grain to the exact spot where it is wanted. Yet there is the fact that yew trees, some little distance from supplies of pollen, bear fruit, ripen seed. The secret of success can only lie in the amazing bounty of the supply; the air must be simply pollinated for a time every spring. 
After our Hampshire yews, our Hampshire beeches. We specialise in them, and grow them to perfection on our grand chalk hangers.

It was a foolish discovery which gravely made up a list of the seven wonders of the world, as if in every field and wood in May there were not seventy wonders as great as Niagara! The change and growth of the beech-tree twig is one of the wonders. Through the winter and the early weeks, indeed months, of spring, the beech was spiked almost like the wild rose or blackthorn. Its buds were rolled and compressed tight as tight could be, and each ended in a point not quite so needle fine as that of a rose or holly leaf, but as hard. The compression was so great that it was not easy to realise that each beech thorn held even one beech leaf. So it continued through much of April; when, from being one of the hardest, driest, thinnest of tree things, the beech thorn began to swell and soften and to lose its sharp point. In March it appealed to the eye and thought as matter about as lifeless as any part of a living tree may be; one day in May we might hesitate to pluck a twig of beech tree, the life and feeling permeating it seemed so quick.

The beech thorn bulging and at length bursting, one is amazed to find-it matters not that one found it the same last May, for these miracles have perennial youth-that a single bud often holds not a single leaf, but four or five leaves, together with a tassel of bloom; leaf and bloom in babyhood, yet 


\section{LIFE AND SPORT IN HAMPSHIRE}

not so unripe but that, a few days from their birtb, they will be shown in perfect miniature, and in a few days more be ordinary beech-tree leaf and blossom. The brown bands that were swathed so tightly round the bud now.drop off, till the ground under the beechtree is littered with them. They made the beech bud a hard thorn, and now they are seen to be as soft and limp as moistened paper.

How is this change in the beech twig wrought in a matter of days? Sap can only ascend-otherwise it would be giving the lie to the law of gravity-through some such device as osmose. To gain matter, on which to feed and fatten, a beech-tree bud must itself give off matter in liquid form, for osmose must be active at the entrance to the rolled leaf as well as at the main doors of the plant, the doors at the root. Thus must not the leaf in the bud or thorn, folded and crinkled into almost nothing, begin to answer to the call of the sap in May, give off liquid and take in liquid, and begin to feed at a time when, if we examine the beech bud, it seems to our sight and touch to be still a hard, unyielding thorn?

From the day when its bud loses the spiked tip and swells into leaf to the day when the leaf is all green the foliage of the beech tree goes through four distinct phases of beauty. A few yards of beech hedge in mid-May will often illustrate each of these phases on the same day, for little chances of soil and sun cause the plants in the hedgerow, like the trees in the wood 
to vary among each other in their time of leaf and flower. First, the bursting bud stage. When the bud, fattening fast each day at this intensely-growing season, reaches a length of two or three inches, it shows three colours. The sheathing of it is partly old gold, partly of a shining, bright rose colour; apparently the old gold-which is the chief colour of these sheathings or shucks that tightly encased and protected the embryo leaves and flower tassels through winter and early spring-turns here and there to this high rose hue. Until the leaf begins to peep through its prison, the rose is not to be seen, only the old gold. The bursting bud shows a third colour, strong emerald green; this belongs to the uncrinkling leaf itself; but I note that the emerald disappears when the leaf has quite cast its wrappings and is spread naked to light and air; the first greens of the beech leaf, when the bud stage is over, are not emerald at all, though we may loosely apply the word to the beech grove in May.

Lying on and along the edges of the emerald folded leaf in this bursting bud stage is a little white woollylooking material. The nature of this material is clearly seen in the second and third phases of young leafing. It consists of softest, silky hairs, which edge the whole of each leaf. What purpose these hairs serve I do not know. I think they are unlikely to be part of any feeding arrangement. May they serve as some guard against frost at the critical time when the wrappings of the bud are peeling off or being thrust aside by the 
swelling leaf within? The beech leaf when very young looks one of the tenderest things, and the most susceptible to frost even when every wood and hedge is crammed with tender-looking things. But whether its look belies its real character I cannot say. The young oak leaves are sometimes singed by frost in May far more severely than those of the beech-one year they were shrivelled by frost at the very end of May.

The second phase of beech beauty is when the leaf is quite free of its wrap, but not yet smoothed out. It is deeply lined, ridge and furrow, like the hornbeam leaf, and, though fairly long, is wanting in breadth. The third phase comes a few days later, and is the most beautiful. I doubt whether there is any greening thing of May more exquisite, more delicate in loveliness, than a little twig of the beech, tree or underwood, in this state. The leaves are now uncrinkled; though they are still ribbed and mid-ribbed distinctly, they have lost the ridge and furrow and are smoothing out into final form. They are half green and half bronze, edged with the white silky hairlets, smooth now and shining a little, and with a gentle droop and poise, especially about the twig tip, that is grace itself. The whole twig is so soft and juicy that it withers almost as soon as it is plucked. In the fourth phase chorophyll has played its part: the leaves are pure green.

I find it hard, in fact, impossible, to look closely at 



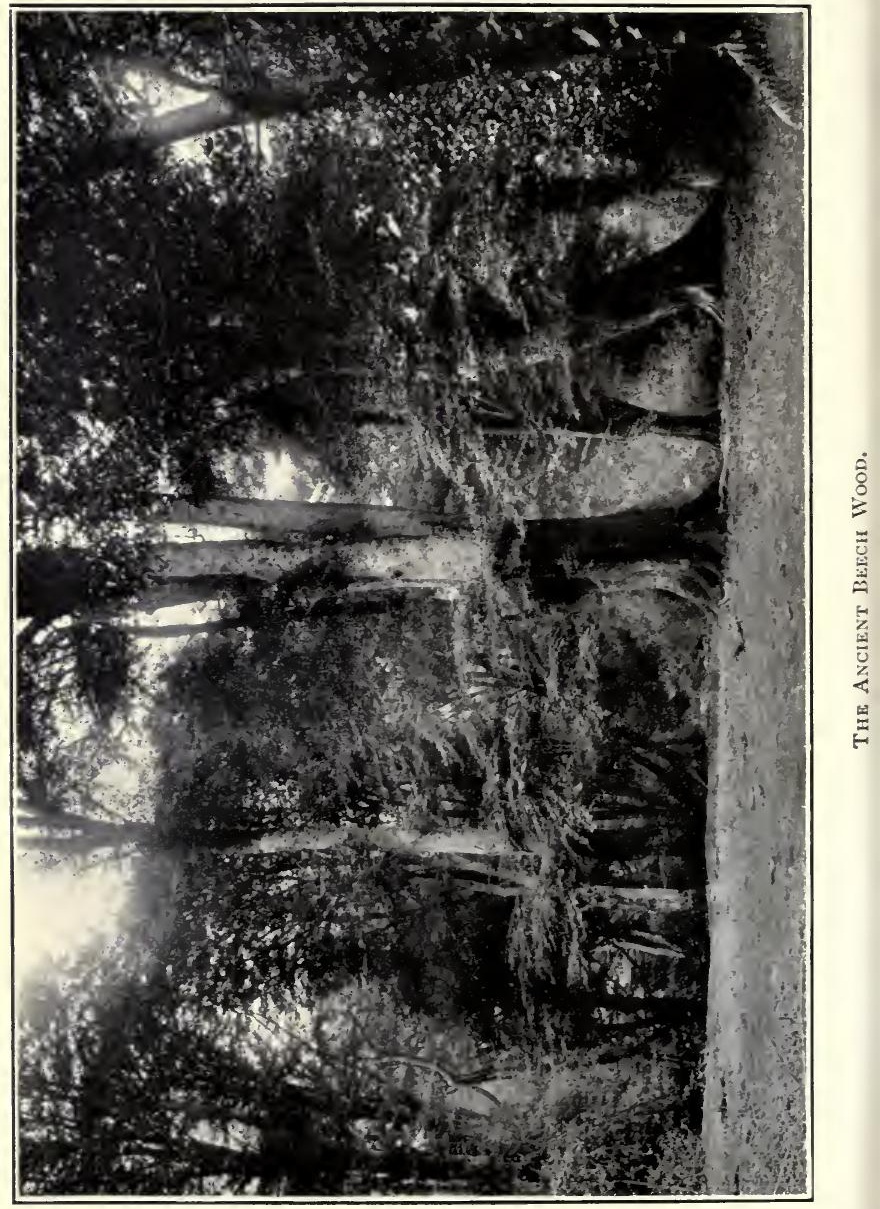


a twig of the beech in the third, the green and bronze, phase, without playing with the thought whether in the scheme of things beauty may not be in itself a powerful law. The way in which beauty is urged, thrust on our constant notice, in a thousand utterly different forms, by Nature, is so thought-worthy. Is it easy to believe that the wonderful beauty and delicacy of the beech twig has no existence outside our own fancy, that it is unessential, of no world concern?

By the time the beeches are all pure green the busiest working day in green life is near. It falls, I think, according to the nature of the season, in late May or early June. It is not the longest day of the year which is the day of heaviest work in the factory of Nature; for by midsummer the sap is well up in the bulk of things, and the machinery, though still active, must begin to slacken. But think what the motive force must be in May!-with every hedgerow, field, and wood growing full green, and the struggle for space and light at its height, a struggle which has no sound or motion to our ear or eye, but not the less is huge in will strength, in its insistent push and uprush. Order and disorder, cosmos and chaos, working together make the summer green. In this strange union of opposites, which is common to green life in every square yard of the earth, it is only the disorder, seemingly the blind chance in things, that appears at a glance. Take a hedgerow facing south, or the 


\section{LIFE AND SPORT IN HAMPSHIRE}

uncultivated, tangled corner of a field which the plough never touches. In the rank competition that prevails among grasses and stouter plants, annual and perennials alike, there is no sign of method, no allotment of space.

The effect to the eye is delightful, but it is a delight that owes nothing to exact arrangement, to careful apportioning of soil and facilities for sunlight between the various eager rival and neighbour plants. To find an economy of arrangement we have to turn to the highly-farmed field itself-and even there, on soil carefully ploughed and weeded, and harrowed and rolled, and sown in drill, and even thinned perhaps, the chaos of the wild is ever striving to insinuate itself.

This side of green life in these teeming, intenselygrowing days of the year is the laisser faire of Nature. Everything is thrown on its own resources, must take its chance haphazard in the thick struggle of May and early summer. True, the number of plants on many a yard of soil which shoot up, and find enough breathing space above and root space beneath to thrive and flower and seed, is astonishing -and here arrangement might seem to prevail, an arrangement that not one inch of earth or of light space above this inch shall be wasted. But then the host of little seedlings that, as the tangle shoots up, must be starved and spoilt! The successes in this open competition-however many in one square yard of earth-are a very few compared with the failures. 
The laisser faire side is the obvious side. We cannot be blind to it. We can easily produce an illustration of it for ourselves by dropping a pinch of dust-fine seed on a foot of soil, and let alone the seedlings when they appear, and they will throttle and thrust and starve each other out, just as they do in the wild. But there is the other side that does not show on the face of things, but is everywhere working out of sight, working tremendously in May days and nights. This is the side of method and cosmos. Each kind of green thing is furnished with machinery of growth exact, most orderly and efficient, working with clocklike precision.

It is the factory of green life; and on the perfect May day in the wood, the air full of sun, and the soil with just the right amount of moisture, all the myriad wheels are a-whir. Here, at least, order is a living presence. It rules even in the turgid little cauldrons of sappy matter which-because it is turgid -is bubbling from cell to cell within the plant and driving through the vessels, finally in the leaf to reach the kitchen of the plant, the mesophyll, where it will quickly be cooked into nourishing food, on which the plant may grow to flower and seed-hood.

Given enough earth and air space, every plant is fitted, through this machinery of pump and pressure, and this factory of food, to perfect itself and fling abroad its seed. But here provision and order end. Fitted out with the nucleus of a machinery that 


\section{LIFE AND SPORT IN HAMPSHIRE}

may cnable it to succeed and grow into a perfect plant, each green thing is flung forthwith on its own resources. Stark competition is the hard world into which it must enter; and if by chance it has been sown in overcrowded or unkind soil, or if its neighbours have the start of it in germination, it must perish, unless above the average in strength. So, after exquisite provision comes merciless competition. This is the sequence; or, taking the two opposites together, this makes up the scheme of green things that is being worked out in sappy May days.

I have turned from our Hampshire Highlands and visited the noble woods and the lawns of Lady Cross a little after this primal rush of summer. The oaks there are at the full, and yet at the fresh of their leaf about midsummer. There nothing of the flush of red and spurge yellow, of the tones and undertones of spring, is left even on the latest trees. But the whole wood is even then not at quite the full green, its floor of fern scarcely matches yet its roof of oak, for the bracken phase is incomplete. Bracken is a great feature of an English wood. After oaks and beeches, it is the chief contributor of green to the forest, certainly to the New Forest. I put it, for this, before pine and spruce.

The vast abundance of the bracken fern is brought home to one better in the first half of June than at any other season. True, till midsummer is come 
and gone, it does not show its full extent of green, but now, before its branches, platform-like, are spread to their utmost, is the time to see how great is the number of fern stems, and how thick they stand in many places. Scores of these stems, springing beautifully straight from the soil, can be counted on a yard or two of favouring soil. It is impossible to walk in the oak woods of the New Forest early in June without bruising and crushing, almost at every step, sappy stems of bracken, with their singed-looking tops.

Instinctively knowing this, we may now and then try to pick a way between these thick-spread stems; for the brake fern, at this stage, has somewhat the look of a feeling, half-conscious thing, where its soft, brown, clawed tip is unrolling into frond form, so that it is repugnant to us to stamp upon it; but the attempt to thread a way between the stems has soon to be given up, unless we confine ourselves to the paths or tracks through the wood. Even in many of these trodden spots bracken is seen springing from the hard surface, for, like the snowdrop in February and the chervil, this fern in May and June will thrust through a beaten-down surface, lifting and pushing aside not only dead leaves and wood litter, but hard, caked clay or gravel.

For its purpose of bursting through the soil when the surface of the earth is baked and hard from want of rain and other causes, the bracken fern is in a 
way well built; the soft, swelled top, a bundle which holds in embryo the delicate fronds, is bent or doubled down so that the comparatively tough stem is given the work of making a way for the fern head. Once through the soil, the hoop of the bracken begins to straighten up, but, where the fern grows high in the oak woods the stem-dead straight save for the top-may shoot up two feet or so before the bend disappears. Now, if the fat, soft little bundle at the top of the stem were carried upright through the earth it might be maimed in piercing a hard surface, just as might the flower-heads of the snowdrop, which, thanks to the same device, can be forced up, made to drive through a hard rolled surface of gravel.

Brake fern then, like chervil, has this iron will to thrust up through floor of adamant to the light, warmth, and food of the air-for breath is food, and the leaf breathes. Perhaps it is as well worth thought as even the quaint method of alternate generations by which fern makes fern; that charming little story of a secret union that begins with spore, continues with prothallus (heart-shaped quite appropriately), and ends in fern.

The huge driving will of plants is seen, indeed, more or less in every soft greening thing in May. It is unconscious will, without individuality and without freedom; and for this reason it is, beyond comparison, more regular and enduring than that which rules our conduct. But though shown in every leaf and root, it 
seems specially developed in the cleaving and clambering plants that are striving upwards in the thickets of early summer. Then, in all our hedges on the chalk, cleavers or goosegrass is shooting up, line upon line of it, and the twining fingers of the traveller's joy above are clasping at the air. These feeling fingers will clasp other fingers, petioles even of the same parent stem; for it is a trait of traveller's joy that, once above the hedge top, its thousand fingers intertwine and interclasp. Traveller's joy is one of the most independent of climbers. Its lower stems steadied in the body of the hedge, it wants no further support from neighbour or rival. It throws up a great mass of flowering stems above the hedge, and these simply wreathe and twist about each, making the great clematis tangle in which the linnets and greenfinches rear second broods.

Not that traveller's joy is peculiar in this independence. It is to be seen in many lowlier things; seen in the hairy tare; to disentangle the grappling tendrils and slender branches of a group of hairy tares is harder than to disentangle a confusion of old gut casting lines and flies pressed in a manyknotted bunch. It is odd to notice the fingers of the climbers feeling towards each other whilst they are still inches apart. The plant has no power to see its neighbour on whom it may depend for support. How does it become conscious of this unseen neighbour, and begin to grow towards it? We notice the single, long, 


\section{LIFE AND SPORT IN HAMPSHIRE}

wiry hooking apparatus of the bryony pointing its fine tip at a neighbour it has discovered and wants to grip. Take away that neighbour, and return a day or so later, and the bryony's feeler will probably have altered its aim, and be pointing towards some other bit of green.

Attraction, repulsion-these are forces at work everywhere among green things at this season of immense energy and power. The smaller plant or the more backward plant is turning, writhing aside and away from its neighbour that threatens, as it spreads, to take up all the sun and air, and so the food and breath. Here is repulsion; I suspect that almost every yard of green ground would show repulsion. And then attraction-the victim, luckless loadstone, drawing to itself a climber that is cruel, and with serpent coil may smother its support; the bindweeds often spoil the poor plants they twine about with a terrible grip.

The blind, but in the end sure, search of the bryony trailer for support is one of the oddest sights I know of. Sopping days and nights, followed by hot sun, will give this bryony a great impetus. Yards of it will shoot up and writhe and coil about the woodland lane where a fortnight before not an inch showed above the ground. The bryony trailer when bald of leaves is one of those plants that wear an animal look. In some of the climbers one is almost oppressed by the look of half-consciousness, of a mind made up to coil and spire to the fore and top of the hedge at the 
cost of anything within reach; even a look of watchfulness. Black bryony and bindweed are climbers that seem to advertise most publicly their fell purpose to grasp and smother their neighbours.

The tip of the bryony trailer has a kind of fanciful likeness to a snake. It is but a blossom in embryo, yet it might, by its appearance, be the most sentient part of a half-plant, half-animal. Its dark green, sometimes its bluish, lengths have a very snaky coil -they remind me of a viper reared up, wicked, ready to strike and to squirt poison. A most startling thing about the bryony trailer is when it adventures forth from a thin hedge-where, through close trimming in the autumn, there is now little support save grasses and small plants-feels out its path two or three feet over the lane; and then, finding no cover within reach, turns back! These adventures are often to be seen where bryony grows along the lanes. It is adventure with risks. Some passer-by may strike at the trailer with a careless stick, or thoughtlessly give it a pluck with his hand; or a cart wheel strike it down and cut it off; and there is a wound that must take the bryony a week or two to cure. But if no further ill befall the trailer, it will return to the hedge whence it came.

How it knows its search is vain in this direction we cannot tell. But know it must, for it will always return to shelter. Noticing this habit, is it strange we should be struck by a certain animality about the 


\section{LIFE AND SPORT IN HAMPSHIRE}

plant? The bryony trailer might be called a creature of green life. If it has no understanding of its own, what an appearance of understanding is here!

But how came the bryony trailer to make the mistake of faring out over a lane where it could not find climbing facilities? And, having fared in vain, how came it to recognise and mend the error? Perhaps, at the start, its passion for climbing is not so strong, and, in these first crude days of the plant's growth out of the soil, the main business is just to throw out anywhere a foot or two of trailer.

The bryony, if not interfered with, returns to the hedge, I think, always in the same way; it coils upward and round. It would seem as if it must be a great strain on the trailer to hold the weight thus in the empty air. Every hour the weight upheld is growing. But with growing weight comes growing strength. This fetches back the bryony trailer to the hedge. On its return it may find some straight stemmed plant, say jack-by-the-hedge. It grips poor jack and wraps round and round to the very flower head three or more neat coils. Then, still back on its journey to the hedge, where by now may be some real support. How the coils, loose at first, tighten on the black bryony's victim as the trailer grows stronger! But even bryony's grip is kind compared to eglantine's, which will deform the hard wands of hazel, so that we fashion them into grotesque walking-sticks. 


\section{THE GREEN WORLD}

The ruthless power of these climbers and their mysterious intelligence are worth the study we can give them. A series of exact trials with the bryonies and bindweeds might be of value. We want to know how far they can feel a neighbour plant; and whether a plant of large bulk attracts them more than a plant of lesser bulk. It would be curious to try to cheat the bryony trailer; on its return hedgeward, to fix a support in the ground just behind, so as to lure it back to the lane; and then, if it turned back, to take away this support, and see if the climber coiled round towards its parent hedge once more.

"The mind of a plant"-how our fathers would have scouted the bare idea of such a thing! The idea of a plant with any sensitiveness, or feeling even, would have struck them as wholly absurd-somewhat as if one were to credit a pebble, say, with a desire for motion. Even now-with all our talk and theory about the wonderful devices of plants, their sensitiveness, the knowledge their roots often seem to have as to the best paths to take for food and sure hold-the mind of a green thing is something we can only half imagine. Perhaps the idea of a certain body or physical intelligence distributed through the various parts of the plant, root, leaves, and flowering machinery is easier to entertain. A mind seems to need a seat in which to sit, a place to be concentrated in. A plant has no headquarters. "It has no head," we think, "how, then, can it have a mind!" But the physical or body 


\section{LIFE AND SPORT IN HAMPSHIRE}

understanding of many green things, this really is at times an idea we can play with quite seriously. It may appeal to us when we see the red bryony stretching forth its tentacles in the hedgerow. This red bryony belongs to an order of plants different altogether from the black bryony. It is a gourd, cousin to melon or marrow, which it reminds us of in several ways, such as shape of leaves, which have an ornamental outline, of the kind the chisel of the sculptor might cut.

The look of physical intelligence in red bryony is in the feeler or tentacle, six inches or so long, pointed and slightly bent round at the tip. This, stretched out in the air for some days perhaps, in the end grasps and winds around leaf, stem, flower, or tentacle of some neighbour; and once it has fastened, an odd thing happens : commonly, at about its middle, the feeler twists like a little spiral spring, an inch or two of twist. This, by shortening the feeler, may strengthen the bryony's hold. It draws itself nearer to the object grasped, or draws the object grasped nearer to itselfaccording to whether the bryony has the greater pulling or the object seized the greater resisting strength. The tip of the bryony feeler gradually closes tighter on the object seized and casts round it two or three neat, tiny coils, like those of a rope coiled on deck by a sailor's hand. The feelers are not very tough, and have none of the woody strength and hardness of the winding stem of black bryony, but they fix the climb- 
ing plant securely enough to the hedge. The feelers, seizing an object on either side alternately of the stem, fix the plant firmly. They pull, as it were, against each other.

Wild clematis, scrambling everywhere, anchors itself somewhat as does red bryony, but has no distinct feeler; round the object seized it winds one of the stems which carry its leaves. These stems serve as a separate tentacle, and are very tough and stronghaving a far greater weight and mass to bear than the red bryony, they need be so. One of these clematis grappling stems will coil as many as five times round some object, usually another clematis stem. So tough and wiry are they, that in May or June the dead and dry grappling stems and the four or five coils of last May's growth cannot always be broken easily by a hard finger pull. Strange that matter which in its rushing growth was so largely composed of water should have to-day, when all life has long dicd out of it, such strength, such a wiry, resolute grip !

All these hedge climbers suggest to me the idea of an intelligence of the body. They suggest it as much as the little round-leaved sundew, drosera, which we found in Blackmoor Forest with yellow asphodel. But their methods of climbing often differ widely. Black bryony is python among plants: it coils its cruel body round and round the victim. So does woodbine. The red bryony, as we see, steadies itself in quite another manner- $a$ fine-pointed, twisting feeler on one side, a 
corresponding one on the other side. Clematis economises; the little stalk that holds the leaf must here and there twine about a neighbour to help steady and uphold the whole plant, though how it is decreed that this stalk or petiole shall twine, and that one not twine, we do not know. Does chaos or chance decide it? If so, it looks as if there must be some effective ruling principles in chaos, or clematis could never be steadily reared and held in position at the hedge-top.

Fourth, take the ivy's method. Here the climbing and grasping method is little like that of bryonies or clematis. The ivy roots itself in. Everything it seizes it grows into, becomes almost parcel of. Here, perhaps, is the fastest plant hold of all ; and it need have a firmer hold than bryonies and clematis, for it is a hold not for a summer season, a few weeks, but for many seasons, a hundred or more. All these climbers really climb, really grip. But there is a class of plants in the hedgerow that hardly can be said to grip, if to climb. The sticky goosegrass leans against the hedge in wavy lines and layers, more or less regular; the white bedstraw sprawls and clambers anyhow. They are so weak and flaccid that the lightest pull tears them singly or in masses from their quarters in or against their hedge-host. As the black bryony's growth and grip bespeak resolution, the bedstraw's whole demeanour seems to bespeak irresolution; force in bryony, feebleness in bedstraw.

But these looks of bedstraw and goosegrass belie 
them, for these sprawling, leaning habits, this stickiness of the goosegrass, really are strength. They have fitted the goosegrass to succeed beyond any other plant in the crush and tangle of the hedgerow which, in its every inch of space, expresses fierce competition for sunlight and soil. In Nature limpness and softness are very far from disqualifying in the struggle of life. The goosegrass is only one of ten thousand proofs of this.

The signal difference between the intelligence of a plant and the mind of an animal in some cases strikes me as just one of slowness of movement and fixity of station. There are plants such as this black bryony which have such a look of animality about them, seem so sensitive-even so watchful! - that one may hesitate to pluck or handle them roughly. One would rather crush an aphis or a caterpillar in the rosebud or tender young leaf unfolding than one would stamp on the black bryony trailer, feeling queerly its way across the tangled lane in May.

To take the black bryony trailer among plants and, among insects, the yellow and black barred caterpillar of the cinnabar moth, which in August is seen on our common feeding up for its chrysalid stage on the leaves of the ragwort: does the caterpillar much more convey to us the notion of mind than the trailer of the plant? I cannot say that to me it always does. About both there seems to be a physical intelligence. The feeding, feeding almost incessant, of this yellow 


\section{LIFE AND SPORT IN HAMPSHIRE}

and black caterpillar of the ragwort, what is it but an act of physical intelligence? Shake it off the ragwort. Presently it will climb up a neighbouring plant. It seems to test the leaves of this new station, and, finding that they are not the right sort, refuses to nibble. But this is merely intelligence of the sense of taste, a physical matter. The black bryony would in the same way refuse to feed on substances that Nature has not included on its menu if these were set at its rootlet tips. It would be just as intelligent about its food, and just as fastidious as the caterpillar: indeed, many plants are much more fastidious and discriminating in this than many caterpillars; which, their ordinary food plant failing, or being denied them, in captivity will eat each other. The one mysterious matter in which the caterpillar seems more intelligent than the plant is "shamming death." The bryony, at any rate, never does that; or, to put it in a way that is a little less unacceptable -Nature never shams death for a plant when an enemy threatens it. The most Nature perhaps does is to provide it with a coat of prickly armour, spining it as she spines the hedgehog or bristles the "woolly bear." The cinnabar caterpillar seems more sensitive than the full-grown caterpillars of the peacock butterfly; but its conduct, when shaken or assaulted by finger or twig, is slightly different from that of the baby caterpillars of the peacock butterfly. When it drops off the ragwort leaf it always lies in the same 
position, not oddly writhed and twisted anyhow-the very counterfeit of death-as they lie, but neatly curled into a round, like sleeping cat. Curled thus, the cinnabar's caterpillar remains dead-still for several minutes. Shake a little party off the ragwort, and for two or three minutes not one of them stirs. Then the first ventures to uncurl, straighten out, and begin to crawl up a stem of ragwort or of any other plant near by; a second and third follow within the next halfminute or so; but one or more will be still curled up and motionless at the end of the fifth minute, perhaps through the shock. This is the sole act of seeming intelligence which inclines me to put the caterpillar of the cinnabar on a higher plane than the climbing plant.

True, a caterpillar will often weave a snug and beautiful cocoon for passing its chrysalid state in. But how does this argue more consciousness, a higher mind, than certain actions of plants? Look at the plant's arrangements for the carriage and disposal of its pollen; look at its seeding devices; above all, look at its resolution to produce seed, though, by robbing it of its blossoms, we try to prevent it making seed. With its system of nerves, the caterpillar may be more sensitive to pain than the plant, but, even so, I am not sure this points to a higher intelligence, to the possession of some sort of mind. On the whole, the intelligence of the bryony is no bad match for that of the caterpillar, and in either case one may 


\section{LIFE AND SPORT IN HAMPSHIRE}

qualify the word intelligence by putting "physical" before it.

Ere I end this talk of plants and these flowers fancies I must say something of our wonderful bugloss fields in Hampshire. They lie some fourteen miles from the great wood and in a very quiet part of Hampshire. For wild-flower glory I have never seen anything in England to equal the scene in 1907 in one spot on the chalk downs. There the bugloss fields were blue as a clear June sky. The poppy and charlock on poor soils, and the sainfoin and deep red clover on well-farmed ones, and, in the wet, gravelly coppice, the red campion sheeted alongside the blue hyacinth-these have long been familiar to me. But bugloss we only look for here and there on the chalk, at most half-a-dozen plants of it together, more often single plants scattered, like the blue succory, along the turf of the road or lane side. At one spot in the chalk downs by Micheldever-the chalk being only a few inches below the poor, dry, top soil-I found the bugloss covering fairly large patches of ground in 1904. Even that was a rare show for bugloss. But since then the plant has thriven and grown ten thousandfold till in 1907 it formed two grand fields of azure.

The blaze of bugloss blue cannot be seen at more than about half a mile away, for the carrying power of this colour in plants is not so strong as that of broom 


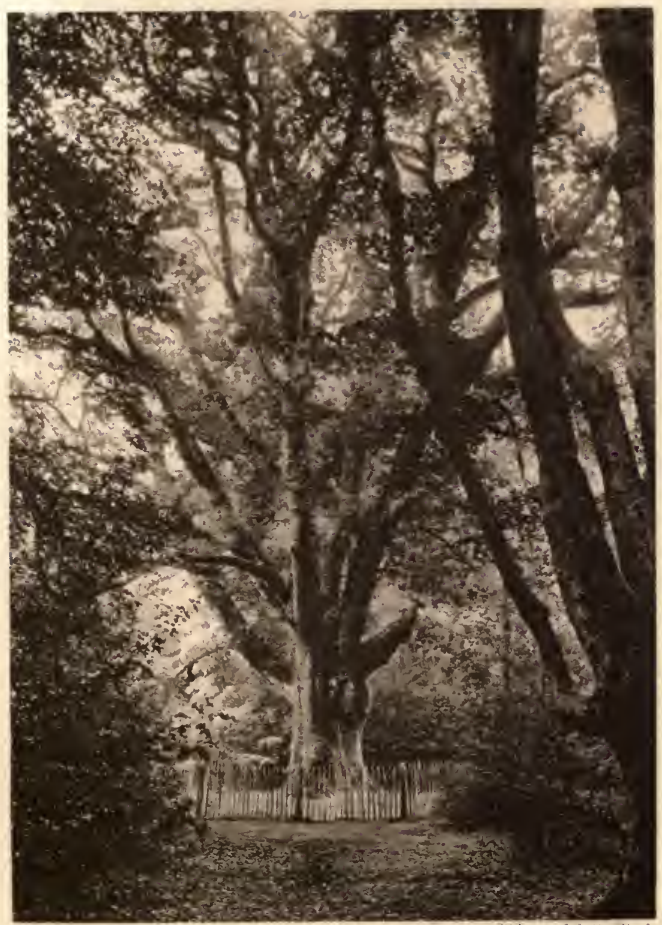

Willort.tolls.9hito.

The Ereat Knighturood Bak 

gold or poppy flame; distance subdues it; but on the spot it surpasses either of those, I think, in beauty. The colour varies from intense azure, or speedwell blue, to that sky tint in which Mars is lamped on a cloudless evening, the darker shades being more general; but blue is not the only colour, though the commanding one of viper's bugloss. Many of the blossoms, like the lungwort's, have a touch of red, or rosy, about them, which runs into purple. I found the whole field humming. The hive bees and humble bees were eager on every bugloss stem, and there were some plants that put out six splendid spikes of blue, spikes often growing four feet high. Imagine forty acres of ground in a high spot covered with a great, even crop of bee larkspur, and you have a picture not more richly painted than this bugloss ground.

But the setting of the field of azure makes it so incomparable among the flower-colour spectacles an English summer gives. The bugloss is blossoming on these hills of God quite six hundred feet above the sea, and from its ground we look on our noble Hampshire panorama of tree-capped hill, bare down, and oak and hazel woods, whose darkening green is such a sombre, restful feature of July. The azures of the sheeted bugloss, and next them, on the side and crest of another wave of chalk down, and in the trough between the two waves, a full twenty acres of poppy - making a perfectly smooth, even sheet of scarletand, beyond this, green fading into misty purple. 


\section{LIFE AND SPORT IN HAMPSHIRE}

Such is the scene in its grander feature of colour and form.

But it is far from all bugloss and poppy along the crests and sides, and in the hollows of these heights. Marching with the bugloss is a large field that has returned to Nature, its soil being too poor for farming in these days. And here is acre on acre of yellowgreen-or is it green-yellow?-flower spikes of the wild mignonette; with purple knapweed and thistle; and, in one corner, the delicate blossoms of drop-wort, charming spiræa of the chalk downs. Even these do not complete the flower census of these wild nursery gardens. Here and there among the mignonette and the dropwort, with its pink-tinted buds and creamy white opened petals, the dry ground is carpeted with thyme, which has spread thither from the unploughed turfs of the downs. These, however, are the ordinary details of scent and colour which are to be found all over the chalk downs in July. The sheeted bugloss is a very different thing. It is one of those flower communities or societies that spring up and thrive on a particular bit of wild or half-waste ground, through some favouring causes we can rarely account for. Union in these cases is strength. By bulk of seed the bugloss overcomes and drives forth all its rivals, as scarlet poppy does on the next wave of down land. By its bulk of blossom it draws the bees from miles around, and I cannot doubt, listening to the hum in these blue 
fields, that it is the policy of bugloss to make and offer honey to the bees.

Honey is by way of tip to the porter who carries the pollen.

The bugloss might, no doubt, have painted these fields a burning blue without aid of bee; and, other things favouring, these fields might turn blue again many summers to come without this pollen porterage. But I cannot question that the bees, visiting perbaps again and again every blossom on these million spikes of blue, ever stirring and mixing the pollen, tend to keep the whole crop up to high efficiency. 


\section{CHAPTER XI}

\section{THE NATURAL MAN}

We must not blind ourselves to the truth that the young villager to-day often finds the country dull and quiet, and will be off to the louder life of towns. But the English village, even the old thatched hamlets in outlying places, where life to the young countryman is dullest of all, is not that scene of blank desolation that some of our friends imagine. Are there villages in England from which all the brawn and endurance, all the physical virtue, have gone? Fishing far into a summer night in Norway, I lost my way in the remote Hallingdal, near Rolshuus, and wandered till morning in a strange twilight, trying to find my inn or station. By-and-by I came to a village, and knocked at a cottage door. There was no answer, the door gave at a push, and I walked in, to find all deserted; cottage after cottage was the same. Here seemed to be some village of a dream. We must wander far to find such a spot as this at home: the exodus of the peasantry from our villages, even the dullest and poorest, is not the least like that I found in Hallingdal. There is dearth of strong labour in many places, sometimes grievous 
dearth; but what splendid physical manhood an English farming village, one of tilth and pasture mingled, still can show! To take part in an election the farmer lent his men a great waggon and a pair of cart horses; and before sundown they started for the neighbouring village three or four miles off to cast their votes. They took some cans of beer with them, and had drained these dry enough ere turning home. But they were not greatly in liquor when, the votes cast and the groups about the polling-place broken up, they crowded back into the waggon. They were full of heart and careless good humour, and at one accord broke into a loud song that seemed all rollicking chorus, in spirit like an old west country favourite, "The Jolly Waggoner," with plenty of refrain in it about "working men."

I watched the great horses as they clanked and stamped up the little slope, starting very slowly. The last trace of colour had worn out in the west, Venus was lit over the trees, all the landscape in monochrome. The burly frames of the singers silhouetted against the sky, and it was fine to see the movements of their arms, swinging to the music, a rude rhythm in the action. There was one, and one only, who could have set this grand scene of the earth-worker on his canvas, the Titan among those who have painted peasant toil, Jean François Millet. Science in our public affairs, book-learning general among all classes of our people, are great things no doubt; 


\section{LIFE AND SPORT IN HAMPSHIRE}

but physique, bodily might, such as was packed into this scene, counts high. An empire wants at its bank a big standing balance of peasant manhood.

We have more smallholders in our part of England than some people imagine. A sunallholder, who has won and kept his bit of England by character and toil, is an aristocrat-the strength of the best in him. $\mathrm{He}$ will make his way not because of Fortune, but despite her. Having known and sympathised with this type of English villager all my life, I say, with conviction, that we cannot create him by laws and governments - at least, not by any direct process. We might as well set about creating by law a good poet or successful doctor. Encouragement by the State is another thing: the principle of it no doubt is right, but the application, I think, very difficult.

The smallholder who has risen from plain farmworker to landowner or tenant-farmer in miniature owes all to character; and character he owes to up-bringing, environment in early years, and something, perhaps, to heredity or his forefathers: say the finger of God picked him out. There is one I have watched and talked to who lives in a hamlet by a wood-edge, a place so trifling and out of the beaten way that even in the Ordnance Survey, an inch to the mile, it was marked only by a dot; and, in the ordinary road maps, the lane that leads to this hamlet is not marked at all. I have watched 
this man going to or returning from his field or two with his horse and cart and with his womenkind, for wife and daughters work on the land as they would in France. I knew, from what he told me, that his bit of land was poor and unpromising when he got his lease of it, but I only realised later the patient, immense toil which has made it fit for a crop. It needed more preparation than plough and harrow, couch fire, and manure to fit that rude land for wheat.

At either end of the wheat field I found a huge heap of stones full five feet high, and covering as much ground as a city garden. It looked as if there must be a hundred tons of stones at least in each of these heaps. Each flint was picked up separately by hand, and put on a small heap. When the small heaps grew and grew all over the field, the man went round with his old cart and horse and shovelled them up, and carried them off to the corners, and there piled them in these two great heaps.

And still the women gathered and gathered, and for each flint they gathered four others seemed to grow.

See flints picked on such a field a little while, and you will realise the truth of this. I watched stonepickers at work once on a bit of grubbed woodland at my own home, and the field was hardly clear of flints than lo! the field was thick with flints. Stones grow, English peasants who toil on flinty soil have 


\section{LIFE AND SPORT IN HAMPSHIRE}

told me, and it is not quite a fallacy. To-day the smallholder's field is thick again with "everlasting flints," only not too thick for cultivation: his first crop of corn has grown gold. The obscure hand labour of this man and his family would count high, were a record kept of such patient endeavour. But then, perhaps, the work would lose its lustre. The virtue of such work appeals to us chiefly because its advertisement and reward are so small.

The success, then, of the best type of the smallholder is the success of character-and character is not State-made. In all plans to strengthen the English peasantry we have to remember this. How character-let us say country character, though probably the restriction is unnecessary-is built up is another thing. The hardest, most enduring :samples of it are, I think, made in this way: home training - the three R's of character-at the start; and then a plunge-without aid-into the roughs.

No rope from the shore to cling to when the waves strike and threaten to overwhelm; and good deep water to sink in if the swimmer loses heart-the deeper the water the more the strong swimmer likes it.

No doubt there are other successes that do not come through the roughs, successes of chance, environment, high gift; but they are not the worthiest, and not the most valuable to a country. They want grit; want that touch of flint witbout whose binding and resisting substance the life of the man and the 
nation is not durable. Writing of this some years ago, I put the smallholder into two classes, the Natural Smallholder and the Artificial Smallholder. ${ }^{1}$ The natural smallholder must, in the main, come through the roughs. He must find and seize his chances. As I say, you cannot make this man by Act of Parliament. He makes himself. I have no politics in thought, saying this, at least not politics in the more restricted sense; and, if it were possible to bring into being smallholders worth the name by State creation, I would wish to see the State passing many Acts to this end. But it is unthinkable in England to-day. When the scientist learns to build up a man in his study out of elements of life and matter, the State, by Act of Parliament, may make of that new man a successful smallholderor artist, or doctor, or statesman-not before. Something can be done by the State to turn the efforts and serious thoughts of people towards the workanxious, hard, and excellent-of making themselves independent through the soil. ${ }^{2}$ But we have to bear in mind that this aid is a trifle in the struggle for success; and that, if you try to make more than a trifle of it, the end must be blank failure. To undo character by well-meant, ill-thought Act of Parliament may not be easy-but it is the easiest thing to discourage the forming of it.

1 I think this is Lord Rosebery's description too.

2 It is being done now. 
These thoughts on character may, I fear, seem to some to be praise of quality hard as our field flints, self-seeking, and unkind. I might please the man of sentiment better by trying to bring out the softer traits of that village worthy who has struggled upwards to a little independence through the land. No doubt these worthies have the kinder side of which the keen driving of a bargain and the stern daily endeavour and the eye on the main chance are not part. Browning says that a man has two sides to his soul—one for the world and one for his wife, and this is as true of the villager who has made his own way by the soil as of any man of action who must depend on his own efforts, not the aid of others. But it is idle to overlook the great worth to a country of the flint-hard side of character. Without this quality, in a world of struggle, a good man moves on a place of quicksands, and there is no safety for himself or-what is worse to him-for those whose welfare depends on his own.

A peasantry or a class of small farmers in England to-day who have not in their constitution the flint and the oak-wood of character, must end in wretched ruin, and they might pull down with themselves a whole country-side. Any mind of sense that knows about the fight of English life must hold this view, yet we find people of sense favouring plans for forcing a plentiful crop of small farmers under glass. True, under glass such plants of State gardening might 
spring up thickly enough, and thrive so long as a fostering hand thinned and pricked them out, and shut the frame against the least nip of frost, and opened it to the sun. But put these tender things into the open, and let them shift for themselves in the struggle of every day, and they must wither and die. Few of these plants, I fear, would be fitted for a world of frosts and droughts and blight.

Thrift, such as must be the stern daily exercise of the natural smallholder, can have in cases, I recognise, an ill-ending. The village miser who owned Hawk's Perch, the shanty at the wood edge, was an instance of this. Up to a certain rung his rise on the ladder might scarcely be distinguished from that of the peasant type that we value greatly. He rose, I suspect, by sure inches very much in the way we associate with sterling peasant quality. A pig at the start; later a cow and a plot of meadow and a little wooden shed to house his live stock in-a shed knocked together by himself. I remember, too, that this man-who died worth thousands in kind and sterling securities-opened a mean little village shop. Its window often held a row of apples and plums grown in his own garden, and some trifling crockery and boot laces. It was hard to believe that money could be made out of this musty little business, seeing that anything the man sold was sold in at least as good measure at the large shop of all wares across the road. Yet it had patrons, and was worth keeping 

rods, trimmed and split, takes even a quick and deft hand an hour to turn out. The maker gets fourpence a hurdle. Many can recall the time when he got much smaller pay. No wonder a good man should now and then be sorely tempted, if not to scamp, at least to haste with his work. $\mathrm{He}$ may be a great worker, earnest to make the utmost out of his day in the copse. On a fine February day, in his prime of life and labour, he may make his nine hurdles-three shillings. Late in the spring, weather favouring, he may make a dozen, if the material is ready at hand directly he reaches his frame about daybreak. Here is a four-shilling day; twenty-four shillings a week if he could reckon on six such days, but what hurdler ever could? He may feel that he must make his hurdles quick, whilst the sun shines-lay up the little he can against bad days, perhaps bad seasons, coming. He may put it to himself that a few finishing touches, mere artistry of the work, will not make the employer of his labour or the buyer of his hurdle richer; whilst they would make him poorer; poorer, say, by fourpence a day, two shillings a week, a very serious sum if he is to put by a little in the village savings' bank against old age.

Here then we have the attitude of the woodman who strives to make a dozen good, workmanlike, but not exceptional hurdles in a day. On the other hand is the woodman, proud of his fame as the most finished hurdler in the district, who works slower and is 


\section{LIFE AND SPORT IN HAMPSHIRE}

content with a smaller output; who will not put a hurdle on the stack till it is perfect in each detail. Which is the wiser? A ready-made answer comes easily to the lips-"Why, the man who makes less hurdles, and finishes these to a touch." But I am not so sure. Perfect work for its own sweet sake is an inspiring thing to consider. Yet it is a fine thing, too, for a village worker to place himself and his family beyond danger of the poor-house in the lean years to come, by the strength and quickness of his daily toil ; and the man who can turn out his ten or even twelve workmanlike sheep hurdles in the day is of the sort who do not often come on the rates.

I am not referring here to lazy or to unskilful hurdlers whose work will hardly stand a season's wear. Unhappily, we find such men working in some copses to-day, though not, I believe, in our own. They served no apprenticeship, they have only been employed to make hurdles because the number of skilled woodworkers in many places grows less and less. In some districts not a wattle hurdle-maker is left today; the old hands are dead or past the work, and the lads do not take kindly to life in the coppice. So the farmer and the wood-dealer must depend on casual hands, whose work would shame the hurdlers of the old school.

The maker of wattle hurdles in the ash and hazel coppices is not the only wood worthy who is growing scarce in England. There is the man who cuts the 
ripe underwood, laying it in rows or "lands," who sorts out and makes it up into bundles for firewood. But bundle is not a term recognised in this craft. It may be a faggot, a puff, a knitch, a bavin. A single county may employ all these terms for a withy-bound bundle of firewood, but what is a puff in one group of woods or one district in the county may be faggot or bavin in the next. That faggot maker who has worked all his life in the copse has an intimacy with wood which we cannot get through print or intelligent inquiry. He knows to a nicety the fuel value of each kind of tree and underwood in his copse. He can tell the right amount of exposure to weather which his cut woods should have, so that they may make the brightest fire. $\mathrm{He}$ can tell the difference between the white birches and the black for other purposes than those of fuel; he has a sure eye for hop poles, young underwoods fit for crates, tough and older underwoods that may be used for rough fencing work. But, after all, the faggot means firewood, and next to the sheep hurdle the faggot must remain the chief product of the ordinary oak, hazel, ash, and birch underwoods of England. Serious, then, is the revolution which in many places has almost abolished the bundle of large and small firewood mixed. Even in outlying villages hawkers of coal drive a small trade, and the new grate is little fitted for underwood fuel or the lop and top of trees. What fire is so comforting and cheerful as one of wood-well-seasoned ash and 
oak-blazing in the open hearth ? The little cracks and simmerings, subtler undertones, the flicker, the clean grey ash; these are so pleasant in the wood fire. One can feed it, too, without soiling the hands; and, once the wood is warm and dry, and there are glowing embers, a touch with foot or fingers will make the flame shoot up again. Yet it is going out of favour in the country. Often I find faggots rotting in woods - our own and others-where they have lain for years. It was never so when the farmhouses and cottages had great brick hearths and chimney corners, and all the village bakers made their bread in ovens heated by the wood fire. Then a single village baker, with a good business, would burn more than five thousand bavins in the year, and the bidding for firewood was keen. We may come back to the wood fire some day, but now it is ousted by coal and little oil stoves.

For weather wisdom that is won by watching, go to the wood worthy. $\mathrm{He}$ still can be trusted. Though the weather-wise countryman has not quite gone, I suppose he is doomed. Many of his old rule of thumb predictions as to wet weather or fine, hot or cold, have been smiled away. He swore by the moon. With large, slow finger-handier at the farm or woodland tools than in separating the pages of books-he would turn over his thumbed almanac to find the age of the moon before he said for sure whether we might look for a continuance of the fair weather or the foul. 
It was astonishing how often he was right-though, perhaps, we forgot to tell against him the times he was wrong. But the moon is out of vogue. We may be allowed to foretell wet when we see a halo round her, because the cloud that takes this form is often a cloud of rain. We must not, however, attach any importance to the age of the moon, to what quarter she chances to be in; this has nothing to do, so far as is known, with the weather of the earth.

Besides, our weather wisdom to-day is ready-made. We buy it as we buy any useful, everyday commodity. There is no longer excuse for unscientific observation. The new plan has great advantages. True, it is not always so positive as the method of the old countryman. It never foretells forty days of wet or of shine as he would-though perhaps that foretelling should come under the head of folk-lore rather than rule of thumb wisdom-but we feel it is based on knowledge and instruments exact and sure. Yet, gaining much, have we not lost a little? The countryman who, dispensing with the almanac, can make the sky his timepiece and his weather-glass is not to be despised. He is full of original, of knowing observation. He seems equipped to deal with clouds, and may not cloudland be largely an unexplored region of lesser weather wisdom? There is a very beautiful cloud form which, when seen in the evening or night sky of autumn or winter, to me foretells wet. Whether it float serene at a great height, or drive swiftly through the air, it seems nearly 


\section{LIFE AND SPORT IN HAMPSHIRE}

always to bring wet. This is when great expanses of the sky are dappled thickly with fleecy cloudlets, filmy rather than opaque. They pass quickly through various changes in form, each cloudlet, as it were, keeping time with its fellows; but they will keep for some time their dappled look. This is a form of cirrocumulus.

For beauty these fleecy flocks of pale grey or white are scarcely excelled by any cloud. Changing slightly in appearance and packing closer together, they are often ruffed out into "mackerel back." Why these clouds, that look not the least rainy, should so often come shortly before a break in the weather, I cannot say; I am sure they do. A short time after they have gone the stars are hid completely by a pall of cirrostratus cloud, spread from horizon to horizonthe dark, rainy form of cirrostratus-and the night or day grows soaking wet. $\Lambda$ s each of these distinct cloud forms must have its meaning and its story, may it not be worth watching them? Suppose in the end we gain from them no weather wisdom to speak of, the observation is yet not misspent, their beauty being so wonderful.

Ours remains largely a corn-growing neighbourhood. Talk about the small importance of the English wheat crop to-day falls on an unbelieving country ear. A bare generation has passed since English people, with one consent, recognised wheat as the event of all in the farming year, a tradition old and sure as our his- 
tory. Such faiths, deep-rooted in a nation's heart, do not die in a few years; at most, in such a period, their hold over the mind can be shaken. The generation that was born and bred in the wheat faith, however it shake its head over the unhappy figures of decay, does not seriously believe that wheat is going; whilst how can the rising generation quite believe the story when, August after August, it sees the grand crop ripening to gold on weald and down, hears the talk about harvest weather and prospects which its fathers heard, talk as to how the wheat looks, and is the ear heavy, and the crop thick this season, and will the rain hold off, and is there plenty of ready labour in this great corn district or that against the gathering and stacking of the crop at just the right time?

"Ripening to gold" one says of wheat at the beginning of August. Wheat, it may be objected, is never the colour of gold save in sentimental talk. True, it never is the colour of gold in the sense of a sovereign. The gold of a coin or a jewel is utterly unlike this glorious wavy expanse which I look on from my window, rich straw-yellow and sun-made brown, with a suggestion of pink or purple bloom on the weighty ears. Wheat is not in the least gold to the eye in this sense of the dressed-up, wrought state of the metal, any more than the moon shines, or the water runs, the colour of silver metal. These colours are seen sometimes in living, growing things, as on the painted wings of some butterfly or moth, 
260 LIFE AND SPORT IN HAMPSHIRE

but their beauty, I think, is meretricious set against the beauty of ripe wheat. Yet the term wheat-gold must stand. We cannot dispense with it as we willingly would with the watery and sentimental one of silver applied to the moon or the running stream. Wheat-gold is a colour of itself which nothing else has, and nothing perhaps deserves. It carries with it that idea of most solid worth, which the wheat cannot lose even in places where-so folk say-it is now grown for its straw. No garden ever equalled a perfect wheat field in sheeted colour which appeals to heart and brain as well as eye. Acres of poppy or charlock or sainfoin, with all their pageantry, do not move me quite as the perfect wheat crop does, when the scythe is clearing the edges and corners of the field for the machine cutter and binder, and preparing a spot for the elevator and the stack. But one condition is indispensable-it must be a strong thick, clean crop. Not a poppy nor cockle nor scabious flower must thrust up its trespassing head level with the surface of the wheat-gold. A patch of thistles in such a place is a crime against cultivation. A thin crop sprent with flowers and grasses can only disgust us.

Flowers, even flowers intrinsically lovely, mixed with the wheat are ugly growths; they are inquilines; the spots where they flourish in the wheat field, after the straw has grown three feet high and is heavily weighted, are scabs. This need not apply to the 
trifling undergrowth, pimpernel and such like, humble pensioners that take practically nothing from the treasuries of the soil, and enter into no rivalry with the wheat. What spoils the look of the wheat field are the much higher and pushing wild things that race up to air and sun with the stems of the corn. Everything that interferes with the growth of wheat is a base weed. For proof of a good man and true, of the type that makes and keeps a country great, there is little surer than a perfect crop of ripe wheat grown in moderate soil on a small farm; this rarely or never deceives.

Nothing about harvest of late has struck me more than the small part hard human labour plays in its drama to-day. True, in corn fields close to villages little groups, straggling lines of workers and watchers, chiefly watchers, may still be seen. The farmer, "fond of a bit of sport," may come with his gun when the last acre or two is being cut; whilst village boys with sticks stand about at the corners on the imaginary chance of bowling over the hard-pressed rabbits as they bolt at last from their dwindling cover. A day or so later come leasers, gathering stray ears of wheat left after the last official combing of the field. But afar from the villages and hamlets, harvest is often quite solitary work for a man.

In the early morning I looked out from the octagon room on the gently stirring, beautifully even surface of burnt yellow and brown; twelve slumbrous hours later 


\section{LIFE AND SPORT IN HAMPSHIRE}

the whole crop had gone down, lay in neat bundles dotted in lines or curves throughout the field. I was hardly conscious of human action whilst this change went forward.

Perhaps the whole crop was cut and bound with the aid of a single man. All he did was to sit on the machine and jog the cord, reminding the horses when they must turn, and apply the cutter and binder to another row. This aid cannot be called perfunctorythough, even if he slept, it would seem as though the patient, trained beasts might do their work by rotebut it is indirect, subsidiary compared with what it was in old harvest days of scythe or sickle and of hand binding with a wisp of straw. Later on, the human element does come in a little more. We see in the evening of the first day's cutting or next morning as many as four men gathering and piling in tens or twelves the bound bundles of corn.

The trifling band of workers still further grew when the wain entered the field, and the rattle of the elevator sounded at the corner, where the stack was to be built; for we have yet to find a machine to gather the piled sheaves, another to pack them on the rick as well as suck them off the wain: the first may seem impossible, the second improbable, but think of a machine that cuts, binds, and arranges in neat rowsto our fathers, the man who started such an idea would have been a wild visionary. The story of harvest machinery is not fully told yet. 
The harvester, then, is less and less in the harvest field. His great day there is done. Hand labour is such a maker of manhood, the brawn and bone, the endurance and patience, that this change must have its drawbacks. We feel this rather than think it; to reach such a conclusion by logical thought would mean collecting and examining and a lifetime of evidence. There are so many wheels within wheels; energy diverted from hand work in the field may be energy applied to more skilled or brainier work in other branches of industry; and so on. A Royal Commission could not collect the evidence in years which we should need to reason out this question decisively.

One thing we can be sure of: nothing can stop the progress of the machine. We might as well try to stop steam or electricity. The machine is destiny. It is playing a part as little liable to suppression as is Competition. It amounts to one of the fixed laws which there is no erasing from the statutebook. If it be a car of Juggernaut-though who believes this to-day? - hand labour must be crushed by its wheels. Hence I cannot find much enthusiasm for tentative return to the scythe, hand-binding, even the flail which a worthy friend of mine in the fairest of Test villages had thought of bringing back to keep the farm hands on the land in winter. These are but the curiosities of industry.

A south-country villager who has tried his fortune in the land of the great wheat plains is sure at least 


\section{LIFE AND SPORT IN HAMPSHIRE}

of his audience when he returns home, his pockets full or empty. There is a spell for the English peasant about the name of that land which print has done little by familiarity to break. They may have been paraded often in the local paper, those figures of the fertile country where corn is up almost as soon as in, and the ninetieth day from the act of sowing sees it harvested. But in these village things is virtue in hearsay which print cannot quite rival; it is fresh where the other is dry, and is so rememberable; and then it is intimate, and seems to bring the hearer in touch with the soil. There is a group of villages in an old haunt of Cobbett which has sent some of its manhood to the corn plains since I can recall. Sometimes an adventurer will return, fill the place with talk of Eldorado, and then disappear again for years or for ever. One native came home not long since, and the wonder is he has not half emptied the village of its youth by his glowing tales. He told of oats thirty sacks and more to the acre, of land that yielded in successive seasons its heavy crop of wheat though not a load of manure had been carted thither. When first he returned, everything at home seemed done on such a petty scale! Ploughs at work on the sides of the hill looked almost as toys; he could tell the astonished villagers how his team in the great plains was never less than four, and how he would ride the horse instead of jolting in the furrows.

The nature of the soil, of the seasons, the pay, the 
cost of life-each of these must be discussed as if it had not been discussed over and again in this same village up the little vale. But $I$ think the thing that tickled most was one affecting social standing. Fancy "our George" sitting for supper at the same board as his master, and even calling master by a Christian name - a master, too, who is passing rich! It is only the bright spirits of the village that can quite grasp this, and freely remark on it. It is too much for the wit of the majority. They flounder- "Hear thikky!" "Did 'er then?" "Lawk-a-mussy!" This part of the young traveller's story makes the fabled world out there seem to them topsy-turvy.

There was a large wooden box which the returning native had with him. The carrier's cart brought it the last six miles of its journey of thousands-at a pace peculiar to carrier's carts in these out-of-theworld spots. One would have liked to be by at its unpacking. It must have been to the family a very Pandora's box-without the ills. That the various treasures and farming samples might not be shaken rudely on the journey across sea and soil the crevices had been stuffed with hay from the wonderful land, and this hay, like everything else there, seems to be on the large scale; strong and benty, so the village judges of hay find it-and who in a village is not a judge of hay?

The fascinating box-with Hope still at the bottom -was repacked, and the carrier's cart took it the first 
short and stiff stage up the steep hill scattered with loose flints. The native went back to the great wheat plains, and several men from the hamlet followed him. He preached the imperialism of the soil too eloquently for them to withstand it. Yet there were two good things he found at home which he admits are wanting to his new world. One was scenery. In those huge tracts of corn there is nothing so good to see, nothing that will bear looking at so long, as the rounded hill and beech tree steep hanger and little green water meadows of home. There are no gabled and thatched barns, no Early English church spires hidden deep among the elms. The second thing he missed was sainfoin. People bred in a sainfoin land set that crop so high.

The caravans of cattle, once a common sight in this part of England, have gone for ever. They ended when the railway system spread through the countryside. It often took days and nights to move the cattle from one town to another, the drovers sleeping with their herds in the open, where now the journey lasts only a few hours. Certain broad strips of green, and local names and tradition, give a good notion of how familiar the long strings of slouching beasts must have been for centuries, not only in grazing counties, but also in many old-style farming districts of wheat and mutton England. Grassy wastes, known still as "the drove," "the cattle drove," "ox drove," are 
scattered among our downs and lowlands where the crops have been rotated and the turnips grown with little change for six or seven generations past; they are now odds and ends, so that the oldest villager cannot often tell where they led to, much less recall the days when the herds were driven along them. It is curious that cattle should be even more important to England to-day than it was in our fathers' time, and yet that we should see less of it along the roads and in the heart of the country.

The droves have gone, but the drovers remain; they are not so observed, still they are a distinctive figure in many parts of the country. The drovers look the roughest, wildest of men. They seem to dress down to their reputation-though perhaps that reputation is largely based on the dress. Anyhow, out of the cattle pen, if not in it, we can find plenty of human sentiment and emotion among these men, though it is expressed in an uncouth form. The cattle drover is a foreigner to most of us, his dress, habit of life, the queer twist of his thought, almost his tongue. Thrown into his company in the market, or on the road, an educated townsman, even a countryman, might find it hard to understand half his talk; on the surface it has so little likeness to ordinary English life among middle or upper class folk. And why does he never wear the collar of civilisation, even though his business be brisk, and he has silver to spare? That neckerchief-once new, but when?- 


\section{LIFE AND SPORT IN HAMPSHIRE}

tied in a simple knot, seems invariable, the badge of the cattle drover on shaving and clean-shirt days as on all others.

But beneath an uncouth surface the drover is human enough, and English, too, and has the social instinets and sympathies. One day $I$ fell in with several drovers travelling with an old dealer, who, perhaps, had risen from their ranks. The talk turned on a cattle dealer who had just died, and I never heard anything of the kind so interesting. The old dealer had most to tell, for he alone had been to the funeral; he had seen the "Missus" the day before, and the way she told him was this: "We've a vacant chair now, Mr. _-." Then, to eager, deferential ears he described the funeral; anything "more lovelier" he vowed he had never seen. Into the spirit of this the droversthough none of them had been invited-entered fully; one declared, with a voice of longing, that he would dearly have liked to see it. All agreed that their friend was a real loss; each had some little touch of intimacy or jest by which to depict him; one of the drovers, a darkey, who seemed to go by the name of "Little Gipsy," could tell how he had been larking with the man only a day or two before the end, and how the two had joked with one another as to which would live the longer. There was no mistaking the sympathy of these unkempt men, though the subject was jumbled up with most carnal talk of hides, carcasses, or the like. What impressed one most was the clear note of satis- 
faction as to the funeral-all done so beautifully! The finishing touch to a career of worth! The cattle drover, though at times he may scarcely look it, is very human. No gallery of country characters, racy of the soil, should be without his portrait.

Here, I close my story of the wood and its wild life, the great wood I always return to in thought and loyalty after wandering far afield in search of new things. The wood is nearly all my early years. I am under no delusion as to the relative importance of the things of which this book treats chiefly-birds, butterflies, flowers, landscape-and the things that press on our notice demand the best efforts of our thought and energy alike in town and country. The latter are paramount absolutely. There is not, and never will be for the majority of us-nor for the minority, I think-the wood or field life pure and simple, the life undisturbed with Nature. It is a dream of impossible reaction. The trend of things is away from this direct and serene life. But though our future is clearly not this, it is a great and pure refreshment to give up ourselves at times to things of the open air and wild. They help us to see life in its right perspective; and they help us to rest more often from the weight of carnal cares which we make for ourselves through the daily struggle. 



\section{N D E X}

ALum Bay, 181

Angling, the evening rise, 126

Angling, thrall of, 144

Angling our friend, 98

Argus, wall, 180

Arnold, William, 9

Assheton Smith, 8

BAT's flight, 40

Beauty, problem of, 151

Bedford blue, 175

Bedstraw, white, 236

Beeches, 219

Bee, the hive, 32, 200

Bees, sack and slaughter of, 210

Bees and cold, 207

Bird voyage, a great, 85

Birds' reasoning powers, 118

Bird "sentinels," 118

Blackbird's cackle, 125

Blackcap, 60, 70

Blackmoor Forest, 235

Blue butterfly, 165, 181

Bracken fern, 226

Brephos moth, 190

Bryony, black, 230, 237

Bryony, red, 234

Bugloss, 240

Burnet moth, six spot, 191

Butterflies and sun, 180

Butterflies' flight, 18, 174

Butterflies, the study of, 89

"CARPET" moths, flight of, 18

Carrion crow, 74, 75, 113
Caterpillars and colour protection, 183

Cattle caravans, 266

Cattle drovers, 267

Chaffinch, 18, 49, 54

Character of the smallholder, 246

Chervil's will power, 214

Chiff-chaff, 81

Cinnabar caterpillar, 238

Cirl bunting, 62

Cirro-cumulus clouds, 258

Cleavers, 229, 236

"Cluttery" weather, 45

Cobbett, 264

Cole, river, 143

Colour protection, 122, 182

Competition, merciless, in Nature, 226

Cormorant's toilet, 139

Corn, 258

Curlew, 127, 129

Curves, virtue of, 23

DANEBURY, 102

Darwin, Miss, 22

Deane, 60

Distribution of birds, 96

Drones, story of the, 205

Dropwort, 242

Dunlin, 26, 128

EGG-SEARCHER and woodcock, 109

Elm, 43

Emerson's “Compensation," 26 
Emperor moth, 113

Estuary's charm, 127

Estuary sounds and scenes, 129

Evolution, 84

"Eye," the butterfly, 187

\section{FABRE, 84}

Fern and prothallus, 228

Fieldfares, 88

Figure of eight in flight, 20

Flight, bird's body in, 15, 16

Flight, different styles of, 16

Flight of great black-backed gulls, 18

Flight of gulls, 13

Flint gatherers, 247

French partridge, 116

Freshness in Hampshire, 10

Fritillaries, pearl-bordered, 165

GARDEN birds, 67

Garden warbler, 60,72

Ghost moth, 166, 176

Glasses for watching birds, 138

Golden Y moth, 188

Gomphocerus maculatus grass. hopper, 199

Grasshopper's strange movements, 198

Grayling butterfly, 179

Green life, busiest day in, 223

HALLINGDAL, 244

Hazel-brown, 102

Hazlitt, 7

Heath butterflies, 37

Heligoland, 80

Herschell and stars, 135

Hot weather, its effect on birds, 46

Hover of the hawk, 11

Howard Saunders, 62

Huber and death's-head moth, 203

Hudson, W. H., 168
Humble-bee and colour, 35

Humming-bird hawk-moth, 34, 36

Hungerford, 142

Hurdlers, 252

INSECT pleasure, 170

Ivy, 236

KEATs' “The Eve of St. Mark," 9 Kirby and Spence, 171

Knightwood Oak, the, 5

LADY Cross woods and lawns, 226

Laisser faire in Nature, 224

Landscape effects in a wood, 4

Large heath butterfly, 187

Lesser whitethroat, $64,69,71$

Life, compression of, in winter, 191

Linnets, special flights of, 102

Loddon, Hampshire, 39

MACHIN ERY, 264

Manhood in villages, 245

Marbled-white butterfly, 173

Marey, 20, 32

Mark Ash, 5

Marsh titmouse, 79

"Martin-snipe," 149

Mason, 47

Meadow-brown butterfly, 37

Meadow-brown butterfly as dead leaf, 188

Meteorology and wild life, 97

Micheldever chalk downs, 240

Mignonette, wild, 242

Migration as anarchy, 91

Migration of insects, 92

Migration, unanimity and simultaneity in, 92

Millet, J. F., 47, 245

Mind of a plant, 233

Minstead, 5 
Miracles near home, 30

Miser, village, 251

Missel thrush, 45, 51

Moschatel, the tuberous, 214

Mottled umber moth, 182

Mystery of the wood, 3

Nightingale, $\mathbf{5 7 , 5 8}$

OAkley Station, 156

Orange tip butterfly, 163

Owl as insect-eater, 167

Ox-drove, the, 178

PAIN'TED lady butterfly, 185

Paired birds, 110

Partridge, 25, 116, 144, 145

Peacock butterfly caterpillars, 194

Pearl skipper, 175

Peewit, 152, 155

Pepper and salt moth, 183

Pettigrew, 20

Pigeon's bow, a, 76

Pigou, Frederick, 142, 157

Plumage of birds, 136

Porritt's, Mr., moth studies, 182

\section{QUARLey Clumps, 102}

RABBIT shooting, 106

Rabbits, wariness of, 119

Rarity, virtue in, 83

Redbreast, 46, 81, 124

Redshank, 149

Redstart, 64

Redwing, 88

Ringlet butterfly, 37

Rook, 74

Rosebery, Lord, on smallholders, 249

\section{SAINFoIN, 266}

St. Ives Bay, 88

Sand, penetrating power of, 129

Sandpiper, 150
Sands, curious appearance of, 141

Satan, the insect, 178

Scarlet tiger moth, 198

Seagull's toy, 137

Sedge warbler, 49, 57, 59

"Sense of direction" in birds, 93

"Sentinels," duck, 138

Shamming wounded, 121

Shelley, 83

Shooting and angling, 99

Silver studded blue butterfly, 188

Singing weather, 44

Skipper butterflies' flight, 37

Skylarks in October, 44

Smallholders, 246

Snipe's "chuck, chuck," 154

Snow blast, a, 128

Song thrush, 43,46

Starling, 49, 77

Staveley Works, 39

Stillness in winter woods, 123

Subtilised senses, 113

Sway, 5

Sympetrum striolatum, 39

Syrphus, 38

TAlL, a bird's, in flight, 19

Tea-things, poetry of, 100

Temperatures of bee hive, 208

Tennyson, 49

Thrift, 251

Thrush, 48, 50, 52

Traveller's joy, 229

Trees, their appeal to us, 2

Trout fishing, reasons for its attraction, 147

Trout's curve, 24

Turtle-dove, 45

UNDERSONGS of birds, 69

Underwoods, 6

Utility in Nature, 56, 169

VALEZINA, a variety of silver washed fritillary, 184 
WARINESS of wild life, 117, 130 , 133

Weather-wise conntrymen, 256

White admiral butterfly, 37

White butterfly and sun, 176

Wild goose, 104

"Wild Life in Hampshire Highlands," 108

Will of plants, 215,228

Willow wren, 61

Winchester, 9

Wing, tip of the, 12
Witchell and sedge warbler, 49

Woodcock, 103, 105, 107, 111

Wood fire, 255

Wood life, the, 269

Wood life, the charm of, 1

Woodpecker's flight, 18

Wood warbler, 65

Wordsworth's poem on Fox, 47

Wren, 124

Wrens' nests, 185

YEWS, 216

THE END 




\section{THE LIBRARY \\ UNIVERSITY OF CALIFORNIA \\ Santa Barbara}

\section{THIS BOOK IS DUE ON THE LAST DATE STAMPED BELOW.}




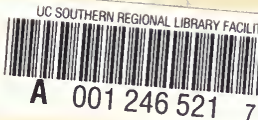


